University of Michigan Law School

University of Michigan Law School Scholarship Repository

\title{
Attempts and Monopolization: A Mildly Expansionary Answer to the Prophylactic Riddle of Section Two
}

\author{
Edward H. Cooper \\ University of Michigan Law School, coopere@umich.edu
}

Available at: https://repository.law.umich.edu/articles/116

Follow this and additional works at: https://repository.law.umich.edu/articles

Part of the Antitrust and Trade Regulation Commons, Courts Commons, and the Supreme Court of the United States Commons

\section{Recommended Citation}

Cooper, Edward H. "Attempts and Monopolization: A Mildly Expansionary Answer to the Prophylactic Riddle of Section 2." Mich. L. Rev. 72 (1973): 373-462.

This Article is brought to you for free and open access by the Faculty Scholarship at University of Michigan Law School Scholarship Repository. It has been accepted for inclusion in Articles by an authorized administrator of University of Michigan Law School Scholarship Repository. For more information, please contact mlaw.repository@umich.edu. 


\section{ATTEMPTS AND MONOPOLIZATION: \\ A MILDLY EXPANSIONARY ANSWER TO THE PROPHYLACTIC RIDDLE OF SECTION TWO}

Edward H. Cooper

$\mathbf{T}$

HE efforts of activist antitrust lawyers to redefine the contours of attempted monopolization under section 2 of the Sherman Act ${ }^{1}$ have again forced the courts to wrestle with the classic antitrust dilemma: How far must single-firm competitive behavior be restrained to make competition free?

The answer given by the majority of current decisions is that, absent some other established offense, single-firm behavior should be prohibited as an attempt to monopolize only when there is a specific intent to monopolize and the firm has come dangerously near to unlawful monopolization.

A contemporary challenge to this orthodox answer is rapidly gaining force. The challenge is based on two premises: First, greater regulation of single-firm behavior is necessary even in the absence of high levels of market power or intent to monopolize; second, creative judicial lawmaking is the best available means of achieving this goal. The legal vehicle for creating such judicial regulatory authority is found in the effort to make attempt doctrine into a self-contained principle, divorced from its present marriage to monopolization. Section 2, replete with its criminal and treble damages penalties, would reach any sort of competitive behavior that is found to be unfair or coercive in its total market setting.

Five examples illustrate the situations that are typically used to justify such an expansion of the attempt offense.

The first is an example of deliberate price predation. An industry that manufactures a distinctive product is populated by four firms: Two widely diversified industrial giants hold fifty-five per cent and twenty-five per cent shares of the market, a small family-owned firm devoted entirely to this product holds fifteen per cent, and a diversi-

\footnotetext{
- Professor of Law, University of Michigan. A.B. 1961, Dartmouth College; LL.B. 1964, Harvard University.-Ed.

The author wishes to express deep appreciation to his colleagues, Professors Peter $O$. Steiner and Charles Donahue, Jr., who reviewed drafts of this Article and made several helpful suggestions.

1. "Every person who shall monopolize, or attempt to monopolize, or combine or conspire with any other person or persons, to monopolize any part of the trade or commerce among the several States, or with foreign nations, shall be deemed guilty of a misdemeanor ...."'I5 U.S.C. \$ 2 (1970).
} 
fied new entrant, far larger in assets than the fifteen per cent firm but considerably smaller than the Big Two, holds five per cent of the market. The five per cent firm cuts prices sharply, to a level far below costs. The large firms do not follow the price cut; they simply continue their prior pricing practices, absorbing such losses of sales as occur for the duration of the price war. After a brief struggle, the fifteen per cent firm is eliminated from the market, its assets are sold for other uses, and its market share is evenly distributed among the three survivors, who emerge with shares of sixty per cent, thirty per cent, and ten per cent. Discovery in the subsequent antitrust suit conveniently produces a resolution of the board of directors of the five per cent firm that prices be reduced "for the sole purpose of destroying [the fifteen per cent firm] so that we might secure a portion of [its] business and thereby increase" our profits. ${ }^{2}$ There is no danger that the five per cent firm will acquire a distinctive "monopoly" power of its own. Accordingly, under the orthodox approach there would not be an attempt to monopolize. The proponent of the illustration, however, concludes with the query, "[I] $]$ n these enlightened times, could anyone imagine that [the fifteen per cent firm] would be denied recovery because it could not prove 'dangerous probability'?"3

The second example is found in the recent attack mounted by the Department of Justice against the two largest sellers of replacement tires. Goodyear and Firestone are each charged, without any claim of conspiracy, with independently attempting to monopolize the same market. ${ }^{4}$ Although the twenty-eight per cent and twenty-five per cent market shares respectively alleged might, standing alone, seem to invite a charge that a "dangerous" approach to single-firm monopoly power exists, ${ }^{5}$ it is nearly impossible to find in either position any approach to such power in a setting where two firms are so nearly equal, each growing and neither enjoying any apparent prospect of eliminating the other. If reprehensible competitive behavior can be

2. The basic situation is taken from Blecher, Attempt To Monopolize Under Section 2 of the Sherman Act: "Dangerous Probability" of Monopolization Within the "Relevant Market", 38 GEO. WASH. L. REv. 215, 221 (1969). The major modification has been to add the passive reaction of the largest firms, so that there can be no possibility of finding a contract or combination between them and the predator.

3. Id. at 221-22.

4. United States v. Goodyear Tire \& Rubber Co., Civil No. C-73-835 (N.D. Ohio, filed Aug. 9, 1973); United States v. Firestone Tire Co., Civ. No. C-73-836 (N.D. Ohio, filed Aug. 9, 1973). Both are summarized in 5 TrADE REg. REP. If 45,073 (nos. 2335, 2336). The complete text of the Goodyear complaint is reproduced in BNA ANTIrRusT \& TRADE REG. REP., Aug. 14, 1973, at D-1.

5. See text accompanying notes $39-43$ infra. 
shown, should courts not be able to invoke antitrust sanctions notwithstanding the lack of a "contract, combination ... or conspiracy" subject to control under section 1 of the Sherman Act?

The third example is that of fraudulently procured patents. If a patentee has sought to enforce a patent procured by deliberate fraud on the Patent Office, is there any reason why liability should not be found without regard to any independent showing either of a dangerous probability that monopoly power will be acquired in some relevant market or of a specific intent to acquire such power?

The fourth example is drawn from the misfortunes created by direct competition between a supplier and its distributor customers. Chrysler sells Dodge automobiles to independent dealers in Pittsburgh. It provides heavy subsidies to a new dealership created by it, enabling the new dealership to undersell the established dealers at loss-creating prices. Is not an antitrust remedy appropriate? Should it matter that elimination of the established dealers, so that Chrysler should become the sole Dodge seller in Allegheny County, would not give Chrysler monopoly power in any relevant market?8

Finally, the Department of Justice has provided a host of examples by including attempt charges in its all-out war on reciprocity practices. ${ }^{9}$ This line of attack has clearly departed from any reference to monopoly power as such. Attempt charges have been leveled against firms whose total market shares are small. ${ }^{10}$ More important, the Department has focused on a "market" comprised only of purchases by actual and potential suppliers to the firm involved. ${ }^{11}$

In the face of these examples, it must seem churlish indeed to ar-

6. "Every contract, combination in the form of trust or" otherwise, or conspiracy, in restraint of trade or commerce ... is hereby declared to be illegal .... Every person who shall make any contract or engage in any combination or conspiracy hereby declared to be illegal shall be deemed guilty of a misdemeanor ...." 15 U.S.C. § 1 (1970).

7. See Walker Process Equip., Inc. v. Food Mach. \& Chem. Corp., 382 U.S. 172 (1965).

8. See Mt. Lebanon Motors, Inc. v. Chrysler Corp., 283 F. Supp. 453 (W.D. Pa. 1968), affd., 417 F.2d 622 (3d Cir. 1969).

9. Reciprocity pressures arise when a frrm makes it known, in some more or less coercive manner, that it prefers to buy from suppliers who patronize it as customers.

10. See A. NEALE, ThE ANTTrRust LAwS of THE U.S.A. $125 \mathrm{n} .2$ (2d ed. 1970) for the notation that the defendant (General Tire \& Rubber Co.) in the prominent complaint that opened up this theory enjoyed less than a five per cent share of its over-all market.

11. E.g., United States v. Crane Co., 5 Trade Reg. ReP. If 45,073 (case no. 2304) (summary of complaint); United States v. Crane Co., 1973-1 Trade Cas. I 74,329 (S.D.N.Y. 1973) (consent decree). An explicit defense of this position was offered in an interview with Professor Turner while he was Assistant Attorney General. See $\mathrm{An}$ Interview with the Honorable Donald F. Turner, Assistant Attorney General in Charge of the Antitrust Division, 34 A.B.A. ANTITRUsT L.J. 113, $122-23$ (1967) [hereinafter Interview]. 
gue that it would be better to continue to confine attempts to monopolize to their orthodox relationship to completed monopolization. Such, however, is the argument advanced here, subject to the possibly redeeming contention that the offense of monopolization might be found in each of the first three examples. Elaboration of the argument will require a detailed examination of the strengths and weaknesses of present attempt doctrine and of the efforts to substitute a much broader doctrine of unfair competition. Nevertheless, the core of the argument may be simply stated, at least for introductory purposes. Judicial competence to evaluate competitive behavior is limited. The predominant lines of present law confine judicial intrusion to areas in which the dangers of anticompetitive behavior are enhanced by substantial elements of market power, in which there is a correspondingly increased probability that a judicial decision to intervene will not upset desirable competitive arrangements, and in which mistakenly depriving a major firm of desirable competitive freedom may not be as grave as imposing the same limitations on a lesser firm. Once the invitation to intrude into areas of lesser market power is accepted, it is difficult to resist the seductive temptation to pass adverse judgment on neutral or even desirable forms of competitive behavior. If the attempt offense is given an independent life of its own, free from any requirement of a close approach to completed monopolization, the dangers of mistaken judgment seem too great to be borne. Absent legislative action, it would be far better to achieve such additional control of single-firm behavior as may be needed by carefully developing the substantive monopolization offense, retaining attempts in their present role as an oft-invoked but seldom employed shield against a contagion that has not quite attained the epidemic proportions of monopoly. Indeed, the only reason for assigning even that narrow role to attempts is the ancient desire to accord at least a superficial function to every portion of a statute.

I. The Slovenly Virtues of Present Attempt Doctrine

A. Attempt in Its Natural Role of Analogy to Completed Monopolization

The wellspring of most current efforts to define attempts to monopolize is the opinion of Mr. Justice Holmes in Swift of Co. $v$. United States. ${ }^{12}$ Although decision could easily have been placed on other grounds even then and many per se violations appear readily to the modern eye, the opinion is devoted to an explanation of attempts

12. 196 U.S. 375 (1905). 
to monopolize in terms drawn directly from ordinary doctrines of criminal attempt. To Holmes, attempted monopolization consisted of conduct that closely approaches, without quite attaining, completed monopolization, coupled with a wrongful intent to monopolize. $^{13}$

It was virtually inevitable that this particular criminal attempt offense should be treated as other criminal attempts and that its content would be found by analogy to the completed offense through a process of determining whether conduct that, for some reason, falls short of the completed offense is yet so like it as to fall within the same proscriptive policies. As will be discussed below, the major difficulties resulting from this approach spring not from the approach itself but from the nature of monopolization as a judicially developed offense that really should not support a cognate attempt offense at all. ${ }^{14}$

Just as it was not surprising that the Court should have treated attempts to monopolize as a close approach to completed monopolization, so it is not surprising that the large majority of current decisions continue to employ the same approach: ${ }^{15}$ Conduct amounts to an attempt to monopolize if there is a "specific intent" to monopolize and a "dangerous probability" that, if left unchecked, it will ripen into monopolization. If there has been any change, it has been the continued development of the monopolization offense itself; whatever may have been the situation in 1905 , when Swift was decided, ${ }^{18}$ monopolization now includes significant elements of economic diagnosis. The same elements have perforce been incorporated into orthodox

13. The Court ruled that the alleged scheme as a whole constituted a violation, noting that the statute gives a cause of action against combinations in restraint of commerce and against attempts to monopolize, and that

Intent is almost essential to such a combination and is essential to such an attempt. Where acts are not sufficient in themselves to produce a result which the law seeks to prevent-for instance, the monopoly-but require further acts in addition to the mere forces of nature to bring that result to pass, an intent to bring it to pass is necessary in order to produce a dangerous probability that it will happen.... But when that intent and the consequent dangerous probability exist, this statute, like many others and like the common law in some cases, directs itself against that dangerous probability as well as against the completed result.

196 U.S. at 396. Although this passage suggests that "dangerous probability" may be found simply as a consequence of the intent to bring monopoly to pass, later parts of the opinion make it clear that intent alone will no more suffice for an attempt to monopolize than for any other attempt: "Not every act that may be done with intent to produce an unlawful result is unlawful, or constitutes an attempt. It is a question of proximity and degree. The distinction between mere preparation and attempt is well known in the criminal law. ... The same distinction is recognized in cases like the present." 196 U.S. at 402.

14. See Parts I(D), II(D), IV(D) \& VI infra.

15. See text accompanying notes $34-37$ infra.

16. See Part IV(B) infra. 
attempt doctrine. ${ }^{17}$ It is accordingly fitting to begin the detailed exposition of current orthodoxy with the market power dimension of attempts before turning to the dimensions of intent and conduct.

\section{B. Market Power Approaching Monopoly Power}

\section{Monopoly Power}

"Monopoly power" for purposes of the Sherman Act is the structural attribute that must be found before addressing the separate behavioral questions that will determine the existence or absence of unlawful monopolization..$^{18}$ Although the Supreme Court has vaguely defined monopoly power as the power "to control prices or exclude competition,"10 the cases that undertake to measure monopoly power focus on the power of the suspect firm to control prices. ${ }^{20}$ The essential question appears to be not whether the firm has some degree of freedom to control prices, but whether it has such a large degree of freedom as to call for corrective action. Along the infinitely variable scale of market power there is a forbidden point called "monopoly power." The forbidden point may well shift, either because of the impossibility of measuring market power in precise degrees or because of ad hoc judgments that more market power may be tolerable in some circumstances than in others. Nonetheless, it is probably reasonable to think of the legal category of monopoly power as a level of market power, persisting over prolonged periods of time, that enables its possessor to charge prices substantially greater than average total costs.

Acceptable levels of market power are differentiated from the levels of monopoly power that trigger the further behavioral questions of monopolization through a two-step process of identifying a

17. See Part $\mathrm{I}(\mathrm{B})(2)$ infra.

18. "The offense of monopoly under \& 2 of the Sherman Act has two elements: (1) the possession of monopoly power in the relevant market and (2) the willful acquisition or maintenance of that power as distinguished from growth or development as a consequence of a superior product, business acumen, or historic accident." United States v. Grinnell Corp., 384 U.S. 563, 570-71 (1966).

19. E.g., United States v. E.I. du Pont de Nemours \& Co., 351 U.S. 377, 391 (1956).

20. See, e.g., notes 23-24 infra. The expressed concern with exclusion of competition reflects a longstanding democratic tradition of fear that "big" business will ruthlessly exterminate "small" business by underhanded means. Ruthless competition may, of course, be supported by large aggregations of wealth, regardless of "market power" in the economic sense. Measurement of "monopoly power," correspondingly, might include an accounting of the assets available to the suspect firm and to its potential victims, but no such effort is to be found in the opinions dealing with measurement of monopoly power. 
"relevant market" and inferring power from the percentage share that the challenged firm holds in that market. ${ }^{21}$

The first step, identifying the relevant product ${ }^{22}$ market, is directed to the determination of whether physically distinguishable products should be included in the market because their characteristics and going prices constrain pricing freedom in a manner somehow comparable to the constraint resulting from the production of indistinguishable products. This determination is expressed in terms of cross-elasticity of demand between products. For example, in the famous Cellophane case, ${ }^{23}$ the Supreme Court determined that there was sufficient cross-elasticity of demand to require that other flexible packaging materials be included with cellophane in a single market in order to determine whether du Pont's seventy-five per cent share of cellophane sales gave rise to monopoly power. ${ }^{24}$

This part of the market definition process involves two wellknown difficulties. First, it requires a projection of customer response to changes in price relationships that have not actually occurred. Second, it operates on the assumption that substitute goods are either wholly in or wholly out of the market and ignores the probability that competition from such cellophane substitutes as glassine is less effective than would be competition from an equivalent value or volume of cellophane. ${ }^{25}$ Although real, these difficulties might not impede a

21. E.g., "The existence of [monopoly] power ordinarily may be inferred from the predominant share of the market." United States v. Grinnell Corp., 384 U.S. 563, 571 (1966). At the same time, it has been recognized that "market share is no holy talisman that alone determines whether a defendant has monopolized an industry." United States v. International Business Machs. Corp., 1979-2 Trade Cas. If 74,613, at 94,715 (S.D.N.Y. 1973).

22. Geographic markets, too, must be measured. For present purposes, however, it is sufficient to concentrate on the difficulties arising along the "product" or "service" dimensions of market definition.

23. United States v. E.I. du Pont de Nemours \& Co., 351 U.S. 377, 379, 394-404 (1956).

24. The Court found the basic test to be the extent to which a "slight decrease in the price of cellophane causes a considerable number of customers of other flexible wrappings to switch to cellophane." 351 U.S. at 400. Later the Court switched perspective to state that substitute products must be included in the market "as customers may turn to them if there is a slight increase in the price of the main product." United States v. Grinnell Corp., 384 U.S. 563, 571 (1966). Although there may well be differences in consumer reaction to price decreases and to price increases from current levels, and although the possibility of decreases has meaning only against an appraisal of costs, it does not seem likely that the Court has meant to require anything more than consideration of broad guesses of substitutability.

25. The shortcomings of market share analysis, noted briefly here, are set out cogently in Turner, Antitrust Policy and the Cellophane Case, 70 HARv. L. REv. 281 (1956).

The problem of excluding substitute goods is posed in particularly poignant terms by the frequently asserted claim that there is sufficient competition along a broad "spectrum" of goods to constrain any pricing freedom that the putative monopolist 
reasonable approximation of market power if an honest and diligent effort were made to utilize the market definition with a recognition of its weaknesses.

More formidable difficulties are encountered at the stage of inferring that the legal conclusion of monopoly power can be drawn from a firm's share of the defined relevant market. Many theoretical reasons ${ }^{26}$ suggest that a large share of even a carefully defined market

might otherwise enjoy. An illustration is suggested by Judge Wyzanski's observation that "customers regard a change from proprietary alarms to [central station protective service] as an entry into what is qualitatively and monetarily a new class, as when one changes from a Volkswagen to a chauffeur-driven Rolls Royce . . . " United States v. Grinnell Corp., 236 F. Supp. 244, 253 (D.R.I. 1964), affd. on market definition and remanded, 384 U.S. 563 (1966). Although there may be relatively little immediate impact on Rolls-Royce prices when there is a change in Volkswagen prices, it is quite possible that the influence of subcompact economy car prices on compact economy car prices, Iuxury compact car prices, economy full-sized car prices, ordinary luxury full-sized car prices, and so on, means that there really is a sufficient degree of constraint to require rejection of any conclusions about market power that might be drawn from occupancy of a $\$ 35,000$-and-up luxury car "market." This possibility is implicitly recognized, and distorted, in decisions that suggest that a merger between Rolls-Royce and Volkswagen would be tested against its impact on a "market" of low-priced cars with rear air-cooled engines and extremely high-priced cars. Cf., e.g., United States v. Aluminum Co. of America, 377 U.S. 271 (1964).

26. In brief summary, the most commonly noted reasons are these:

(I) The character of demand for the product as a whole may be such that, in relation to the costs of production, there is no room for prices greater than costs.

(2) A firm with a large market share may have higher costs than another firm that is capable of expanding its own market share at constant cost. In such circum. stances, the firm with a smaller present market share may actually have greater market power. Illustration may be provided by an example drawn from the realms of physically distinct substitute products. There might, for instance, be a great many users who prefer glassine to cellophane, despite the latter's physical superiority, so long as cellophane sells at a fourteen-cent higher price. If virtually all of those users would switch to cellophane at a price differential of twelve cents and the cost difference in manufacture is only ten cents, any firm that could control the price of cellophane frec from other competition could control not only the price but also the very availability of glassine. A slightly different perspective on the same point is that a firm that has power to control prices may choose to exercise it (whether or not for profit-maximizing motives) by raising prices to a level at which many users in fact find substitutes highly attractive. Inferences that the substitutes are part of the same market because relatively small price changes over the current pattern of price relationships may lead to relatively large switches of purchases, and that since the firm has a small share of the "market" it accordingly lacks the market power of pricing freedom, would of course be entirely misleading. See Brooks, Does Low Market Occupancy Indicate the Absence of Monopoly Power, 4 ANTrTRust Burc. 579 (1959); Turner, supra note 25, at 282.

(3) Barriers to entry by new firms may be so low that any sustained effort to charge prices above long-run total costs will be met by new entry at lower prices. This possibility is particularly important with respect to the special case presented by producers of distinguishable products who are easily capable of shifting existing production capacity and distribution channels to the product involved in the market definition. The Supreme Court has, on occasion, suggested that production interchangeability should be considered in examining the question of market power. See Brown Shoe Co. v. United States, 370 U.S. 294, 325 n.42 (1962); United States v. Columbia Stcel Co., 334 U.S. 495, 510-11 (1948). And the Court has also ignored the matter in the face of a highly pointed dissent. See United States v. Aluminum Co. of America, 377 
might not give rise to an ability to charge prices substantially in excess of costs. Whether these theoretical objections have practical significance is essentially an empirical question, to be answered by determining whether, in the long run, supracompetitive profits, the apparent object of judicial concern, are earned in industries showing high concentration of market shares. Although accumulating evidence indicates that monopoly profits are earned even in industries characterized by a concentrated oligopoly structure whose firms collectively hold a large market share, the evidence is by no means conclusive. ${ }^{27}$

The difficulties with diagnosing the legal category of monopoly power may not be easily overcome; at the least, it will take economic science a long while to develop a process more easily workable and more certain of result.

An alternative resolution of the measurement difficulties is simply to discard any concern with confining the application of the monopolization offense to situations of high market power. As discussed below, ${ }^{28}$ there is substantial support for reading any concern with refined measurement of market power out of the legal category of monopolization. The Supreme Court may very well have started along this road in stating that the market tests under section 2 of the Sherman Act are the same as those employed in measuring mergers against section 7 of the Clayton Act. ${ }^{22}$ The Merger Guidelines of the Depart-

U.S. 271 (1964). In earlier times, the Court expressed a much more general belief that, absent improper conduct by an initially dominant firm, potential competition-"the centrifugal and centripetal forces resulting from the right freely to contract"-would prevent any position of monopoly from enduring. Standard Oil Co. v. United States, 221 U.S. 1, 62 (1911). A perhaps unintentional illustration of the great difficulties of measuring the impact of potential entry is provided by the method of measurement suggested in Schlade, Proposed Objective Relevant Product Market Criteria Under Section 2 of the Sherman Act and Section 7 of the Clayton Act, 35 U. CrN. L. REv. 376 (1966).

27. The major studies finding a correlation between concentration and profitability are listed and rejected in Brozen, Concentration and Structural and Market Disequilibria, 16 ANrTrRusT BuLc. 241 (1971). See also, e.g., Mann \& Meehan, Concentration and Profitability: An Examination of a Recent Study, 14 ANTrrRusT ButL. 385 (1969); Singer, Industrial Organization: Price Models and Public Policy, 60 AM. Econ. REv. 90 (1970).

28. See Part TV infra.

29. 15 U.S.C. § 18 (1970). United States v. Grinnell Corp., 384 U.S. 563, 573 (1966). This suggestion has been accepted by a number of subsequent decisions. E.g., L.G. Balfour Co. v. FTC, 442 F.2d 1, 11 (7th Cir. 1971); Woods Exploration \& Producing Co. v. Aluminum Co. of America, 438 F.2d 1286, 1304-07 (5th Cir. 1971) (finding, in addition, that actual power to exclude competition obviates need for market share analysis), cert. denied, 404 U.S. 1047 (1972); Case-Swayne Co. v. Sunkist Growers, Inc., 369 F.2d 449, 454-55 (9th Cir. 1966), revd. on other grounds, 389 U.S. 384 (1967); Philadelphia World Hockey Club, Inc. v. Philadelphia Hockey Club, Inc., 351 F. Supp. 462 (E.D. Pa. 1972); Twin City Sportservice, Inc. v. Charles O. Finley \& Co., 365 F. 
ment of Justice ${ }^{30}$ illustrate how far a highly adept distillation of the decisions under section 7 can narrow ${ }^{31}$ the market concept in product and geographic terms, so that very small levels of market power can be reached. ${ }^{32}$ Full-scale absorption of similar standards into monopolization doctrine would reduce the required element of monopoly power to a very low level of market power indeed. Obviously, any such dilution of the power required for monopolization will, in turn, expand considerably the reach of the attempt offense.

\section{Dangerous Probability of Monopoly Power in a Relevant Market in Attempt Cases}

A measure of proximity to completed monopolization is clearly involved in the dangerous probability requirement of the Swift opinion, ${ }^{33}$ and cases continue to invoke the requirement in these terms. ${ }^{34}$

Supp. 235 (N.D. Cal. 1972); Credit Bureau Reports, Inc. v. Retail Credit Co,, 858 F. Supp. 780 (S.D. Tex. 1971), affd. on other grounds, 476 F.2d 989 (5th Cir. 1973); Marnell v. United Parcel Serv. of America, 1971 Trade Cas. I 73,761 (N.D. Cal. 1971); Denver Petroleum Corp. v. Shell Oil Co., 306 F. Supp. 289 (D. Colo. 1969).

The Supreme Court had already analogized a section 2 case to a section 7 case in International Boxing Club v. United States, 358 U.S. 242, 252 n.8 (1959).

30. Merger Guidelines of Department of Justice (May 30, 1968), as amended, Merger Guidelines of Department of Justice, 5 TRADE REG. Rup. I 4510.

31. The Guidelines are also adept in demonstrating the possibilities of broadening the relevant market to include remotely competing products, where that avenue affords the most plausible attack on a merger. In monopolization cases, this reach of market definition does not seem to be important.

32. Paragraph 3(i) of the Guidelines, 5 Trade REg. REP. If 4510, at 6882, defines product markets as limited to "any product or service which is distinguishable as a matter of commercial practice from other products or services"; 3(ii), 5 TRADE REG. REP. If 4510, at 6883, defines geographic markets as limited to "any commercially significant section of the country (even as small as a single community), or aggregate of such sections, .... if firms engaged in selling the product make significant sales of the product to purchasers in the section or sections. The market need not be enlarged beyond any section meeting the foregoing test unless it clearly appears that there is no economic barrier ... that hinders the sale from outside the section to purchasers within the section."

33. Swift \& Co. v. United States, 196 U.S. 375, 396, 402 (1905). The position of Justice Holmes is restated in his opinion for the Court in United States v. Winslow, 227 U.S. 202, 217-18 (1913), as well as in his dissenting opinions in Hyde v. United States, 225 U.S. 347, 387-88 (1912), and Northern Sec. Co. v. United States, 193 U.S. 197, 409 10 (1904). See generally Smith, Attempt To Monopolize: Its Elements and Their Definition, 27 GEO. WASH. L. REv. 227, 235, 237-38 (1958).

34. E.g., American Tobacco Co. v. United States, 328 U.S. 781, 785 (1946) (opinion here quotes from the trial court's jury charge; although it is difficult to read it so, many courts have found the quotation to be an approval of the charge); TV Signal Co. v. American Tel. \&: Tel. Co., 462 F.2d 1256, 1261 (8th Cir. 1972); Panotex Pipe Line Co. v. Phillips Petroleum Co., 457 F.2d 1279, 1288 (5th Cir.), cert. denied, 409 U.S, 845 (1972); Cornwell Quality Tools Co. v. C.T.S. Co., 446 F.2d 825, 832 (9th Cir. 1971), cert. denied, 404 U.S. 1049 (1972); McElhenney Co. v. Western Auto Supply Co., 269 F.2d 332, 339 (4th Cir. 1959); Kansas City Star Co. v. United States, 240 F.2d 643, 663 (8th Cir.), cert. denied, 354 U.S. 927 (1957).

As might be expected, the effort to translate the dangerous probability requirement 
Since the modern judicial model of completed monopolization includes measurement of monopoly power by assessment of shares in a relevant market, it has naturally followed that the heavy majority of current decisions require that an attempt involve a dangerous probability of achieving monopoly power in a relevant market. ${ }^{35} \mathrm{~A}$ few opinions, to be examined later, have explicitly rejected any requirement that a relevant market be shown; ${ }^{36}$ these decisions have been as explicitly rejected by many others. ${ }^{37}$

into jury instructions has given rise to the substitution of varying phrases for the original words. See charges set out in ABA ANTTIRUsT SECTION, ANIITRUST Crvil JURY INSTRUCTIONS 81-86 (1972) ("reasonable probability," "actual knowledge that actions . . . would tend to cause monopolization," "would be likely to accomplish monopolization"). Also see Kansas City Star Co. v. United States, 240 F.2d 643, 663 (8th Cir.), cert. denied, 354 U.S. 927 (1957), upholding a charge requiring acts "which, if successful, would be likely to accomplish such monopolization." "

35. Many of the cases requiring demonstration of the relevant market expressly relate the requirement to the dangerous probability of attaining monopoly power. E.g., Bowen v. New York News, Inc., 1973-1 Trade Cas. I 74,590 (S.D.N.Y. 1973); Southeastern Hose, Inc. v. Imperial-Eastman Corp., 1973-1 Trade Cas. 74,479 (N.D. Ga. 1973); H.F. \& S. Co. v. American Standard, Inc., 336 F. Supp. 110, 124 (D. Kan. 1972). Other cases announce the requirement in more general terms. E.g., Bernard Food Indus., Inc. v. Dietene Co., 415 F.2d 1279, 1284 (7th Cir. 1969), cert. denied, 397 U.S. 912 (1970); Advance Business Sys. \& Supply Co. v. SCM Corp., 415 F.2d 55, 69 (4th Cir. 1969), cert. denied, 397 U.S. 920 (1970); Periodical Distribs., Inc., v. American News Co., 290 F. Supp. 896, 909 (S.D.N.X. 1968), affd. per curiam, 416 F.2d 1330 (2d Cix. 1969).

Many of the cases in this area involve claims by terminated distributors that their supplier has attempted to monopolize distribution of its own products. Confining illustrative citation to some of the cases dealing with automotive products, typical decisions requiring measurement of the asserted attempt against a broader market include: Nelligan v. Ford Motor Co., 262 F.2d 556, 557 (4th Cir. 1959); Madsen v. Chrysier Corp., 261 F. Supp. 488, 506-07 (N.D. III. 1966), vacated as moot, 375 F.2d 773 (7th Cir. 1967); Kemwell Automotive Corp. v. Ford Motor Co., 1966 Trade Cas. If 71,882 (S.D.N.Y. 1966); Miller Motors v. Ford Motor Co., 149 F. Supp. 790, 811 (M.D.N.C. 1957), affd. on other grounds, 252 F.2d 441 (4th Cir. 1958). Other cases in this line are discussed with the problem of refusals to deal in Part V(A)(2) infra.

By way of brief anticipation of the deviant lines of authority examined in Part III infra, it may be noted that there are cases that purport to require a "dangerous probability" but that explicitly reject the need for proof of a relevant market, Moore v. Jas. H. Matthews \& Co., 473 F.2d 328, 332 (9th Cir. 1972), or that reject the need for evaluation of the likelihood that, absent intervention, monopoly power would have been achieved in fact, Kearney \& Trecker Corp. v. Giddings \& Lewis, Inc., 452 F.2d 579, 598 (7th Cir. 1971), cert. denied, 405 U.S. 1066 (1972). This approàch may have strong support in the old cases. See Part IV(B) infra.

36. The opinion on which others focus is Lessig v. Tidewater Oil Co., 327 F.2d 459, 474-75, 478 (9th Gir.), cert. denied, 377 U.S. 993 (1964). See Part III infra.

37. The considerable disarray of cases in the Ninth Circuit is examined below. See text accompanying notes 168-70 infra. Other cases explicitly rejecting the doctrine announced in Lessig v. Tidewater Oil Co., 327 F.2d 459, 474-75 (9th Cir.), cert. denied, 377 U.S. 933 (1964), include Acme Precision Prods., Inc. v. American Alloys Corp., 484 F.2d 1237, 1240 (8th Cir. 1973); Agrashell, Inc. v. Frammons Prods. Co., 479 F.2d 269 (8th Cir. 1973), cert. denied, 42 U.S.L.W. 3290-91 (U.S., Nov. 13, 1973); Radzik v. Chicagoland Recreational Vehicle Dealers Assn., 1972 Trade Cas. I 74,167 (N.D. III. 1972); Brewer Sewing Supplies Co. v. Fritz Gegauf, Ltd., 1970 Trade Cas. \& 73,139 (N.D. Ill. 1970); Diamond Intl. Corp. v. Walterhoefer, 289 F. Supp. 550, 576-77 (D. Md. 1968); United States v. Johns-Manville Corp., 259 F. Supp. 440, 451-52 (E.D. Pa. 1966) 
The differences between present and potential competition suggest that greater care should be taken in attempt cases to include all significant substitutes in the relevant market. In a case of completed monopolization, the fact that no substantial competitor has appeared may be some indication that the force of potential competition does not destroy the supposed monopoly power. When the admitted lack of present monopoly power has pushed analysis back into the attempt area, however, the existence of presently viable competitors suggests that potential competition may exert sufficient additional force to check any possibility of monopoly power (or monopolistic behavior). ${ }^{38}$

If monopoly power is inferred from a firm's large share of a relevant market, it is natural to seek to identify a dangerously probable approach to monopoly power in terms of a proximately reduced market share. Several cases have considered the question of the required market share; examination of judicial reactions to a variety of share figures demonstrates that repeated scrutiny has failed to produce consensus even on a zone separating dangerous from innocuous probabilities. Although a thirty-one per cent market share has, for example, been found so perilously close to the line that a decision against an attempt claim was rested on other grounds, ${ }^{30}$ it has also been found that a declining market position currently at fifty-one per cent was not sufficient to create a dangerous probability. ${ }^{40} \mathrm{~A}$ number of decisions have found market shares of approximately twenty per cent clearly insufficient. ${ }^{11}$ Yet, a court that reluctantly concluded that

(civil); United States v. Ghas. Pfizer \& Co., 246 F. Supp. 464 (E.D.N.Y. 1965); United States v. Chas. Pfizer \& Co., 245 F. Supp. 737 (E.D.N.Y. 1965); Becker v. Safelite Glass Corp., 244 F. Supp. 625, 637-38 (D. Kan. 1965); United States v. Johns-Manville Corp., 231 F. Supp. 690, 699-701 (E.D. Pa. 1964) (criminal). One commentator has concluded succinctly that "the Lessig approach reeks of overkill." Hibner, Attempts To Monopolize: A Concept in Search of Analysis, 34 A.B.A. ANrtrRusx L.J. 165, 171 (1967). See also $2 \mathrm{~J}$. von KaLinowski, ANTITRUST LAWS AND TRADE REgUlation (16A Business Organizations) § 9.01[2], at 9-10 (1963).

38. Substantially this argument has been made in urging that market definitions should be broader in approaching merger cases than in approaching cases of singlefirm monopolization. See Steckler, Market Definitions and the Antitrust Laws, 9 ANTrTRUST BuLl. 741 (1964). But cf. Telex Corp. v. International Business Machs. Corp., 1973-2 TRADE CAS. If 74,774, at 95,439 (N.D. Okla. 1973): "[T] relevant markets and the likelihood of success ... become less important in attempt to monopolize cases as aggressive predatory intent and conduct emerge more clearly."

39. Bendix Corp. v. Balax, Inc., 471 F.2d 149, 162 (7th Cir. 1972), cert. denied, 42 U.S.L.W. 3194 (U.S., Oct. 9, 1973).

40. Diamond Intl. Corp. v. Walterhoefex, 289 F. Supp. 550, 576-78 (D. Md. 1968).

41. Hiland Dairy, Inc. v. Kroger Co., 402 F.2d 968, 973-75 (8th Cir. 1968), cert. denied, 395 U.S. 961 (1969); Cal Distrib. Co. v. Bay Distribs., Inc., 337 F. Supp. 1154 (M.D. Fla. 1971) (defendant was second in its market); Allen Ready Mix Concrete Co. v. John A. Denie's Sons Co., 1972 Trade Cas. I 73,955 (W.D. Tenn. 1972) (granting 
it was forced by the weight of authority to require a dangerous probability that monopoly power would be acquired found itself unable to rule, on a summary judgment motion, that the requirement could not be satisfied in a suit against a defendant that enjoyed some five per cent of the relevant market. ${ }^{42}$ 'The lack of consensus reflected in these cases is echoed in the despairing comment uttered by another court, which was unable to find a dangerous approach to monopoly power in a small market share: "[O]ne must be particularly wary of the numbers game of market percentage when considering an 'attempt to monopolize' suit."43

If the zone of dangerous probability may be encountered with a market share as low as five per cent, the requirement is no longer one of a probability of attaining monopoly power. Instead, it has been reduced to a requirement of probable approach to some other undesirable result-most likely, the elimination of a competitor or the curtailment of a competitor's ability to compete. Several cases, however, have concluded that elimination of a competitor is not an attempt to monopolize. ${ }^{44}$ These decisions may seem particularly surprising when set against the common definition of monopoly power as the power to exclude competition, since it would seem that actual exclusion is the best proof that the power exists. For this very reason, the decisions

judgment notwithstanding the verdict to a defendant who was second largest in its market); SCM Corp. v. RCA, 318 F. Supp. 433, $472-73$ (S.D.N.Y. 1970). See also Volasco Prods. Co. v. Lloyd A. Fry Roofing Co., 308 F.2d 383, 389-90 (6th Cir. 1962), cert. denied, 372 U.S. 907 (1963); Smith-Victor Corp. v. Sylvania Elec. Prods., Inc., 242 F. Supp. 302, 313-14 (N.D. III. 1965).

42. Campbell Distrib. Co. v. Jos. Schlitz Brewing Co., 208 F. Supp. 523, 529-30 (D. Md. 1962).

43. Cliff Food Stores, Inc. v. Kroger, Inc., 417 F.2d 203, 207 n.2 (5th Cir. 1969).

44. E.g., Syracuse Broadcasting Corp. v. Newhouse, 236 F.2d 522, 525-26 (2d Cir. 1956); Keco Indus. v. Borg-Warner Corp., 334 F. Supp. 1240 (M.D. Pa. 1971); Kershaw v. Kershaw Mfg. Co., 209 F. Supp. 447 (M.D. Ala. 1962), affd. per curiam, 327 F.2d 1002 (5th $\mathrm{Cir}$. 1964) (it is confusingly concluded that a valid covenant not to compete is not a violation because there is no exclusion of competition; more accurately, it would be found that such an exclusion of competition is not undesirable in all of the circumstances); Evening News Publishing Co. v. Allied Newspaper Carriers, 160 F. Supp. 568, 578-79 (D.N.J. 1958), affd., 263 F.2d 715 (3d Cir.), cert. denied, 360 U.S. 929 (1959); Bender v. Hearst Corp., 152 F. Supp. 569, 578 (D. Conn. 1957), affd. on other grounds, 263 F.2d 360 (2d Cir. 1959) (elimination of competitor by acquisition).

Some of the cases adopting this conclusion are even more obviously correct than the determination that not every covenant not to compete with a potential competitor, or acquisition of a competitor, is an attempt to monopolize. E.g., South End Oil Co. v. Texaco, Inc., 237 F. Supp. 650, 655-56 (N.D. Ill. 1965) (concluding that, even if a relevant market could be limited to Texaco's own products, elimination of one of several competing distributors could not be an attempt to monopolize).

A nice test is provided by the cases discussed in text accompanying notes 178-79 infra, involving elimination of a firm from a market in which the alleged offender does not compete. 
represent an intriguing re-emphasis of the proposition that the diagnosis of monopoly power, and of dangerous approaches to it, is commonly focused on the inferences of price control drawn from impressively high shares of a judicially defined relevant market.

Nonetheless, some recent opinions seek to give content to the dangerous probability element, while at the same time divorcing it from a requirement of approach to attained monopoly power. One court concluded that there need not be an evaluation of the actual likelihood that an attempt would lead to "monopoly status" if not frustrated, but that the dangerous probability requirement instead involves an appraisal of the offender's ability to achieve the "forbidden result," of its intent, and of the nature of its conduct. ${ }^{45}$ How these elements can be measured, and how the "forbidden result" differs from "monopoly status," was not vouchsafed. Likewise, another court concluded that, although proof of a relevant market is relevant, it is not indispensable to proof of a dangerous probability of success. ${ }^{46}$

These opinions lead directly to the question whether the attempt offense should be redefined into an independent wrong freed from the constraining requirement of approach to the monopoly power content of completed monopolization. An answer to this question must await examination of two issues: the role played by the measurement of market power in assessing competitive conduct, ${ }^{47}$ and the ability of courts to improve the functioning of the market place by regulating the conduct of firms possessing relatively low levels of market power. ${ }^{48}$ For the moment, it is sufficient to repeat that orthodox attempt doctrine requires a substantial level of market power. In addition, the doctrine extends the analogy to completed monopolization by imposing the generally rigorous requirements of evil intent and bad conduct to be examined next.

\section{Conduct and Intent Bordering on Monopolization}

It once appeared possible that the Supreme Court would conclude that possession of monopoly power alone violates section 2 without reference to the means of its acquisition or maintenance. ${ }^{40}$ But more

45. Kearney \& Trecker Corp. v. Giddings \& Lewis, Inc., 452 F.2d 579, 598-99 (7th Cir. 1971), cert. denied, 405 U.S. 1066 (1972).

46. Moore v. Jas. H. Matthews \& Co., 473 F.2d 328, 332 (9th Cir. 1972).

47. See Part $I(G)(3)$ infra.

48. See Part V infra.

49. In United States v. Griffith, 334 U.S. 100 (1948), the Court found it unlawful for a group of theater owners to bargain simultaneously for exhibition rights for theaters in towns where there were no competitive theaters and in towns where there were competitive theaters. This combined bargaining approach was condemned on the ground that the purchasing power derived from the towns where monopoly ex- 
recent decisions have ruled that power alone does not complete the offense of monopolization. The added "plus" element of improper conduct in the monopolization offense gives rise in the attempt offense to a cognate requirement of "specific intent"-which includes, and is often shown by, improper conduct. Once again, a brief statement of prevailing monopolization doctrine is a helpful preface to the corresponding attempt decisions.

\section{Intent and Conduct in Monopolization}

The most succinct recent statement by the Supreme Court is that unlawful monopolization requires both the existence of monopoly

hibitor status was enjoyed might be misused to give an unfair advantage in competing for exhibition rights in towns where competition was encountered. In the course of the opinion, it was said that monopoly power alone, "whether lawfully or unlawfully acquired, may itself constitute an evil and stand condemned under $\$ 2$ even though it remains unexercised" and that "the existence of power to exclude competition when it is desired to do so is itself a violation of $\S 2$, provided it is coupled with the purpose or intent to exercise that power...." 334 U.S. at 107.

It would be possible to read these statements to mean that, whenever a monopolist engages in business on terms that do not automatically cause others to enter the market, there is an intent to use the power to exclude çompetition and a violation of section 2. In the pithy phrase of Judge Learned Hand, "the power and its exercise must needs coalesce." United States v. Aluminum Co. of America, 148 F.2d 416, 428 (2d Cir. 1945). During the years immediately following the Griffith decision, many commentators concluded that it and the surrounding opinions had indeed made the possession of monopoly power alone an offense. E.g., Oppenheim, Federal Antitrust Legislation: Guideposts to a Revised National Antitrust Policy, 50 Mrch. L. REv. 1139, ' 1151,1193 (1952); Rostow, Monopoly Under the Sherman Act: Power or Purpose?, 43 ILL. L. REv. 745 (1949).

This literalistic reading of the phrases of decision is misleading. It would at least invite the peculiar conclusion that liability may be avoided by doing business on terms that do not exclude competition. If, for instance, a very efficient firm has the power to eliminate all competition by selling at prices close to cost, it could avoid liability by instead selling at prices high enough to shelter some number of less efficient "competitors." It would be strange indeed to prefer a monopolist who charged high prices to one who charged low prices.

More important, the Court's opinion is simply not written as an opinion intended to outlaw the simple possession of monopoly power. A direct statement was easily available. Instead of making the direct statement, the Court apparently focused on the intent to bargain for all towns simultaneously as the intent to engage in conduct sufficiently injurious to competition to warrant prohibition. See text accompanying notes 96.99 infra. Likewise, the use of the Griffith language in cases decided at the same time involved situations in which the defendants had engaged in a wide range of patently exclusionary activity. See United States v. Paramount Pictures, Inc., 334 U.S. 131, 173 (1948); Schine Chain Theatres, Inc. v. United States, 334 U.S. 110, 130 (1948).

The Court's explicit reliance in Griffith on American Tobacco Co. v. United States, 328 U.S. 781 (1946), moreover, strongly suggests that Griffith meant only that demonstrated exclusion of actual competitors is not required to complete the offense of monopolization. The American Tobacco decision, indeed, turned on the precisely narrowed question whether actual exclusion of competitors is required when it is assumed that large furms have acted together to control the prices of raw materials and of their finished products for the purpose of restricting the effectiveness of lower-priced competition. The determination that actual exclusion need not be shown in such circumstances does not, of itself, carry far-reaching implications as to some more abstract or refined notion of "intent" to exercise monopoly power. 
power and "the willful acquisition or maintenance of that power as distinguished from growth or development as a consequence of a superior product, business acumen, or historic accident."

While this reference to "willful acquisition or maintenance" of monopoly power might imply some independent element of wrongful intent, the contrary conclusion is in fact well settled. If a firm has acquired or maintained a position of monopoly power by means that are found to be unlawful, there is no defense that the firm lacked any otherwise "wrongful" intent. The intent to engage in the undesirable conduct that has supported the monopoly position is enough. ${ }^{.1}$

Definition of the conduct that will outlaw a position of monopoly power is thus critical to understanding the reach of monopolization. The longest reach is surely indicated by the conclusion in the famous Alcoa decision that it is unlawfully exclusionary for a firm with monopoly power constantly to grow with the market, thereby depriving would-be entrants of the tempting invitation of unfilled demands. ${ }^{62}$ Similar conduct by smaller competitors-expanding capacity in anticipation of market growth in order to supply increased demand without inflated short-run prices or some nonprice system of rationing-would represent highly desirable behavior. It is accordingly possible to find in this decision support for the conclusion that the only "conduct" needed to outlaw a position of monopoly power is the act of retaining such power in a mature industry without support in subsisting valid patents, in clearly demonstrable economies of scale that would be destroyed by dissolution, or (perhaps) in the efficiency provided by an indivisible and superior management team. ${ }^{53}$

Less far-reaching conceptions of the conduct element of the mo-

50. United States v. Grinnell Corp., 384 U.S. 563, 570-71 (1966). The Court did leave open the possibility, urged by the district court, that, once monopoly power is shown, the burden might be imposed on its possessor to show that the power is due to skill, acumen, and the like. 384 U.S. at 576 n.7. Decisional authority for imposing such a burden goes back at least as far as United States v. Eastman Kodak Co., 226 F. 62, 79-80 (W.D.N.Y. 1915), appeal dismissed, 255 U.S. 578 (1921). This ploy, and, indeed, the full range of possibilities still open under present decisions, is explored in Kales, Good and Bad Trusts, 30 HARv. L. REv. 830 (1917).

51. The definitive statement is recognized to be that in United States v. Aluminum Co. of America, 148 F.2d 416, 43i-32 (2d Cir. 1945).

52. See United States v. Aluminum Co. of America, 148 F.2d 416 (2d Cir. 1945). There is strong ground to find that Alcoa in fact did not grow progressively with the market, as supposed by the court, but instead lagged behind developing demand. See D. WALlace, MAREET Control in the Aluminum INDUSTRY 252, 259.60, 331, 352-53 (1937).

53. Two leading statements of this view are Turner, The Scope of Antitrtst and Other Economic Regulatory Policies, 82 HARv. L. REv. 1207, 1212-25 (1969); Williamson, Dominant Firms and the Monopoly Problem: Market Failure Considerations, 85 HARV. L. REV. 1512 (1972). 
nopolization offense may easily be developed. The common element in these conceptions is a proscription against conduct that is "exclusionary" because it makes more difficult the competitive success of the firm's rivals and that is not so clearly efficiency-promoting as to be the kind of conduct "which a competitive society must foster." 54

The important difference between these conceptions relates to the point at which a plaintiff must show the existence of such exclusionary conduct. ${ }^{55} \mathrm{~A}$ plaintiff may be required to prove exclusionary conduct as part of its initial case. Or a plaintiff may only be required to show that the defendant possesses monopoly power. To avoid an adverse judgment, the defendant would then be required to show that its position is traceable to an initial accomplishment of economies of scale, to occupation of a market not served by others, to innovative activity, or the like, without regard to the continuing existence of such originating factors. The burden of demonstrating that the continuing position is not due to the "historic accident" that others have failed to perceive available opportunities, to some unknowable present superiority, or to similar factors, would then be returned to the plaintiff, who would be required to show some "exclusionary" activity. ${ }^{50}$

Administration of any of these tests involves obvious dangers and uncertainties. ${ }^{57}$ The important point for analysis of attempts is that

54. United States v. United Shoe Mach. Corp., 110 F. Supp. 295, 344 (D. Mass. 1953), affd. per curiam, 347 U.S. 521 (1954).

55. Any effort to require a negative showing by the defendant that no exclusionary practices had been employed would in practical effect require the defendant to demonstrate continuing justification for its monopoly position of the sort contemplated by the most hostile approach to monopoly. pra.

56. These various possibilities are explored in the authorities cited in note $50 \mathrm{su}$ -

57. The most obvious danger of judicial ignorance is encountered in determining whether activity undertaken by a business firm is significantly more efficient than whatever alternatives appear to be less exclusionary. The difficulties of evaluating competitive behavior are suggested in Part $V$ infra.

An added difficulty is presented by the question whether the undesirably exclusionary activity, once it has been found, has in fact had any impact at all. It seems highly probable that the difficulties of determining whether the abstract exclusionary tendency has actually bolstered the monopolist's position at all will lead to practical reliance on the abstract tendency alone. That is, once the monopolist has engaged in wrongful activities that make it impossible to be certain whether the monopoly position would have persisted in their absence, all doubts will be resolved in favor of dissolution. Thus, many years after the initial decree in the United Shoe case, United States v. United Shoe Mach. Corp., 110 F. Supp. 295 (D. Mass. 1953), affd. per curiam, 347 U.S. 521 (1954), it was determined that dissolution was required, United States v. United Shoe Mach. Corp., 391 U.S. 244 (1968). The need for dissolution was said to depend on the presence of "appropriate findings of violation," 391 U.S. at 250, but at no time was there any coherent determination of the measure of power that the United Shoe Machinery Corporation would have had but for the violations found. $C f$. 110 F. Supp. at 344: “United's control does not rest solely on its original constitution, 
the offense of monopolization may be completed by conduct that would be lawful, and perhaps highly desirable, if indulged in by a firm lacking monopoly power. This aspect of monopolization doctrine creates the greatest difficulties for the process of analogy by which courts undertake to fill out the specific intent and conduct elements of attempted monopolization.

\section{Specific Intent Without Monopolization}

a. Character of the intent. Definition of the monopolization offense encounters the formidable obscurities just described when it reaches nearly innocent behavior. Courts that have undertaken to define the attempt offense have instinctively resolved the problem of analogizing to these obscurities by setting them aside. Analogy is drawn not to the furthest possible extension of monopolization liability, but rather to an assumed model of monopoly achieved by evil behavior that corresponds to the predatory practices attributed-at least in folklore - to the industrial barons of the late nineteenth century. This tendency is illustrated most clearly by statements in the famous decisions dealing with the intent required to complete the monopolization offense itself. These opinions, in ruling that the monopolization offense requires no intent beyond the intent to engage in monopolizing activity, distinguish a supposedly different "specific intent" required to impose liability for attempt when monopoly power has not in fact been achieved.58

Most of the cases undertaking further definition of the required specific intent refer, naturally enough, to a conscious desire to monopolize. ${ }^{59}$ The desire to monopolize is translated further into a de-

its ability, its research, or its economies of scale . . . . Much [how much?] of United's market power is traceable to the magnetic ties inherent in its system of leasing, and not selling, its more important machines."

58. See United States v. Griffith, 334 U.S. 100, 105 (1948); United States v. Aluminum Co. of America, 148 F.2d 416, 431-32 (2d Cir. 1945); United States v. Grinnell Corp., 236 F. Supp. 244, 248, 251 (D.R.I. 1964), affd. as to violation, 384 U.S. 563 (1966); United States v. United Shoe Mach. Corp., 110 F. Supp. 295, 346 (D. Mass. 1953), affd. per curiam, 347 U.S. 521 (1954).

The higher requirement of intent led one judge to conclude that it was proper to convict a defendant of both attempt to monopolize and monopolization for the same basic course of conduct. See United States v. General Elec. Co., 80 F. Supp. 989, 1016 (S.D.N.Y. 1948). The more general tendency is to assume that conviction of attempt merges into conviction for monopolization. See, e.g., American Tobacco Co. v. United States, 328 U.S. 781, 783 (1946); United States v. Shapiro, 103 F.2d 775, 776 (2d Cir. 1939); United States v. Kansas City Star Co., 1955 Trade Cas. If 68,117 (W.D. Mo. 1955), affd., 240 F.2d 643 (8th Cir.), cert. denied, 354 U.S. 923 (1957).

59. A lengthy exploration of the cases may be found in Hawk, Attempts To Mo. nopolize-Specific Intent as Antitrust's Ghost in the Machine, 58 CoRNELr. L. REv. 1121, $1136-49$ (1973). 
sire to achieve monopoly power, ${ }^{60}$ although the original formulation was a more general reference to the desire to accomplish a forbidden monopoly. ${ }^{61}$ (The distinction makes a difference only if, as explored below, ${ }^{62}$ it is decided that a forbidden monopoly can be found without a showing of something meeting the current concepts of monopoly power.) Alternative formulations commonly refer to an intent to acquire power to control prices or to exclude competition; ${ }^{63}$ although it would be possible to read such references as contemplating the elimination of a competitor without the acquisition of monopoly power, it seems most probable that they simply reflect the shorthand definition of monopoly power noted above. ${ }^{64}$

Although courts may find comfort in this reliance on a supposed specific intent, it should be readily apparent that the general formulation cannot limit the attempt offense in any acceptable way.

An initial difficulty, implicit in all the cases, is that specific intent alone is not sufficient to complete an attempt. In addition, a firm must engage in questionable activity in a market setting such as nearly to achieve completed monopolization, or at least to threaten undue impairment of competition. ${ }^{55}$

60. A highly explicit statement is that a mere intent to exclude a competitor from part of the market is not sufficient-there must be a specific intent to acquire monopoly power. American Football League v. National Football League, 205 F. Supp. 60, 64-65 (D. Md. 1962), affd., 323 F.2d 124 (4th Cir. 1963). See also Independent Iron Works, Inc. v. United States Steel Corp., 332 F.2d 656, 667 (9th Cir.), cert. denied, 375 U.S. 922 (1963); Bowen v. New York News, Inc., 1973-1 Trade Cas. I 74,590 (S.D.N.Y. 1973); Keco Indus., Inc., v. Borg-Warnet Corp., 334 F. Supp. 1240 (M.D. Pa. 1971); Crown Packers, Inc. v. Lapeyre Co., 260 F. Supp. 193 (W.D. Wash. 1966) (instruction to jury reported in ABA ANTITRUST SECTION, supra note 34, at 81).

61. Swift \& Co. v. United States, 196 U.S. 375, 396 (1905). See also United States v. Chas. Pfizer \& Co., 245 F. Supp. 737, 739 (S.D.N.Y. 1965); Smith, supra note 33, at 232$33,244$.

62. See Parts I(D), II(D), IV(B), IV(D), \& VI infra.

63. E.g., Kearney \& Trecker Corp. v. Giddings \& Lewis, Inc., 452 F.2d 579, 599 (7th Cir. 1971), cert. denied, 405 U.S. 1066 (1972); Rawlins v. American Oil Co., Civ. No. 89-67, (D. Utah, Oct. 1, 1969), appeal dismissed, (10th Cir. 1970) (instruction to jury reported in ABA ANritrusr SEction, supra note 34, at 81-82); Bailey's Bakery, Ltd. v. Continental Baking Co., 235 F. Supp. 705 (D. Hawaii 1964), affd. per curiam, 401 F.2d 182 (9th Cir. 1968), cert. denied, 393 U.S. 1086 (1969) (instruction to jury reported in ABA ANTTRust SECTION, supra, at 85).

64. See text accompanying note 19 supra. Both forms are combined in Bowl America Inc. v. Fair Lanes, Inc., 299 F. Supp. 1080, 1093 (D. Md. 1969), where the court refers both to the intent to destroy competition and to the intent to build monopoly or to gain control over some relevant market sufficient to set prices in the market or to exclude competitors.

65. E.g., Hallmark Indus. v. Reynolds Metals Co., 489 F.2d 8, 12 (9th Cir. 1973): "[S]pecific intent must be accompanied by predatory conduct directed to accomplishing the unlawful purposes." The obscurity as to what sort of conduct must be shown is, of course, the obscurity surrounding attempt doctrine as a whole. The questions of evaluation of conduct and the importance of market power are explored in several sections below. 
The more fundamental difficulty is that a specific intent to acquire monopoly power may often be entirely legitimate. Several cases have explicitly ruled that an effort to become the sole firm in a market that can support only one firm-a "natural monopoly"-is not a prohibited attempt to monopolize, even though the monopoly is currently being enjoyed by an incumbent. ${ }^{B C}$ More generally, a specific intent to become the sole firm in the market by virtue of competitive superiority alone does not satisfy the requirements of an attempt to monopolize. ${ }^{67}$

Finally, just as a specific intent to acquire monopoly power is not in itself sufficient, so too the lack of any affirmative desire for monopoly power should not prevent the imposition of attempt liability. Nost of the cases establishing this point are concerned with inferring a fictive "intent" from conduct that is found to be undesirable." $\mathrm{A}$ more bizarre illustration is provided by a case that involved a legitimate, regulated monopolist selling natural gas. In order to promote gas sales, it sold gas appliances at prices that threatened to destroy independent dealers and recouped its expenses through gas sales. The court apparently ruled that there could not be an attempt to monopolize when there was no purpose to monopolize the gas appliance market. Reversing summary judgment for the defendant, it remanded for trial solely on the question whether there had already been an unlawful monopolization of that market. ${ }^{69}$

It seems highly likely that situations of this sort will occur only if the firm already enjoys a position of monopoly power in some market and is in a position to misuse that power. ${ }^{70}$ Ample support exists

66. The leading opinion is Union Leader Corp. v. Newspapers of New England, Inc., 284 F.2d 582 (1st Gir. 1960), affg. in part 180 F. Supp. 125 (D. Mass. 1959), cert. denied, 365 U.S. 833 (1961). See also Lamb Enterprises, Inc. v. Toledo Blade Co., 461 F.2d 506, 515 (6th Cir.), cert. denied, 409 U.S. 1001 (1972) (claims of conspiracy to monopolize and restrain trade); Parmelee Transp. Co. v. Keeshin, 292 F.2d 794, 803-04 (7th Cir.), cert. denied, 368 U.S. 944 (1961); Ovitron Corp. v. General Motors Corp., 295 F. Supp. 373 (S.D.N.Y. 1969); United States v. Harte-Hanks Newspapers, Inc., 170 F. Supp. 227 (N.D. Tex. 1959).

67. Dahl, Inc. v. Roy Cooper Co., 448 F.2d 17, 19 (9th Cir. 1971). Cf. Travelers Ins. Co. v. Blue Cross, 481 F.2d 80 (3d Cir.), cert. denied, 42 U.S.L.W. 3352 (U.S., Dec. 10, 1973); Bailey's Bakery, Ltd. v. Continental Baking Co., 285 F. Supp. 705, 719 (D. Hawaii 1964), affd. per curiam, 401 F.2d 182 (9th Cir. 1968), cert. denied, 393 U.S. 1086 (1969).

68. See Part $\mathrm{I}(\mathrm{C})(2)(\mathrm{c})$ infra. 1966).

69. Southern Blowpipe \& Roofing Co. v. Chattanooga Gas Co., 360 F.2d 79 (6th Cir.

70. A roughly comparable situation was presented by Bergjans Farm Dairy Co. v. Sanitary Milk Producers, 241 F. Supp. 476 (E.D. Mo. 1965), affd., 368 F.2d 679 (8th Cir. 1966), where both monopolization and attempt to monopolize were found. There, a milk producers' cooperative with lawful monopoly power over the supply of raw milk in its geographic market sought to extend control into the processing area, in order to maximize the percentage of locally produced milk devoted to the Class I use, which by virtue 
in present law for treating such conduct, the improper use of an otherwise legitimate monopoly, as an unlawful "monopolization."71 If, however, some unnecessary difficulty is interposed to this solution, there is no reason why attempt liability should not be imposed despite the lack of "specific intent." Although the firm does not affirmatively desire monopoly power in a second market and may even be unaware of the possibility that it may arise, its conduct threatens competition and lacks significant redeeming virtue. Courts should be able to halt the conduct before it reaches the fruition of monopoly and to provide a civil remedy to those injured by it.

Plainly, then, the "specific intent" required in attempt cases is not simply a subjective intent to prevail in the market. Instead, it is the intent to indulge in means that are in some sense untoward.72 Whether the means must be untoward merely in the sense that, if they were to establish a position of monopoly power, the power would be unlawful, or whether they must be somehow more offensive, will be explored below. ${ }^{3}$

b. Extrinsic evidence of self-evaluation. Although the specific intent component of section 2 attempts is ordinarily no more than a conclusion that objective conduct was undesirable, attention to direct evidence of subjective intent has some value.

Most obviously, in many cases courts have accepted an explanation of legitimate business purpose for challenged behavior, thereby finding that it did not constitute an attempt to monopolize. ${ }^{74}$ While

of the peculiarities of federal milk price regulations returns higher prices for the same milk than result from Class II uses.

It has been argued in more general terms that firms operating in a regulated monopoly market and in a competitive market may find it profitable to operate below cost in the competitive market. See Noll \& Rivlin, Regulating Prices in Competitive Markets, 82. YALE L.J. 1426, 1427 \& n.6 (1973).

71. Primary reliance would be placed on United States v. Griffith, 334 U.S. 100 (1948). See Part $\mathrm{I}(\mathrm{C})(3)(\mathrm{c})$ infra.

72. See Hiland Dairy, Inc. v. Kroger Co., 402 F.2d 968, 975 (8th Cir. 1968), cert. denied, 395 U.S. 961 (1969); Luria Bros., 62 F.T.C. 243, 603 (1969), enforced, 389 F.2d 847 (3d Cir.), cert. denied, 393 U.S. 829 (1968); Kales, The Sherman Act, 31 Harv. L. REv. 412 (1918); Rostow, supra note 49, at 770-71; Smith, supra note 33, at 231-32; Note, Attempt to Monopolize: The Offense Redefined, 1969 UTAH L. REv. 704, 714. Cf. Bergjans Farm Dairy Co. v. Sanitary Milk Producers, 241 F. Supp. 476, 484-85 (E.D. Mo. 1965), affd., 368 F.2d 679 (8th Cir. 1966); Handler, Industrial Mergers and the Anti-Trust Laws, 32 ColUM. L. REv. 179, 254-55 (1932). Blecher, supra note 2, at 217-18, is characteristic of a divergent strain of thought that recognizes that honest competition involves exclusionary intent but that argues that, nonetheless, conduct otherwise honestly industrial can become unlawful simply because of predatory intent.

73. See Part $\mathrm{I}(\mathrm{C})(3)(\mathrm{b})$ infra.

74. See Times-Picayune Publishing Co. v. United States, 345 U.S. 594, 626-27 (1953); United States v. Columbia Steel Co., 334 U.S. 495, 532-33 (1948); Six Twenty-Nine Prods., Inc. v. Rollins Telecasting, Inc., 365 F.2d 478, $485-86$ (5th Cir. 1966) (establishing guides 
direct evidence of legitimate business purpose is, of course, subject to serious credibility doubts, nonetheless it must be considered. Business conduct may be legitimately motivated by matters undreamed of by judicial tribunals. More important, evaluation of business conduct without reference to motivation increases the risk of incorrectly evaluating its desirability. The very fact that the court is prepared to believe testimony of motivations it would not have shared stands as a strong caution against substituting judicial judgment for business judgment. If it is accepted, as will be argued below, ${ }^{75}$ that courts should intervene only in clear circumstances, direct evidence of actual motivation may be important in a surprisingly large number of cases.

Far less common are situations in which a plaintiff affirmatively shows a defendant's predatory intent by evidence extrinsic to the challenged conduct itself. An example might be the incredibly condemnatory memorandum set out in the Introduction, ${ }^{70}$ in which a board of directors deliberately recorded its purpose to eliminate a competitor by predatory pricing. Such external documentation, when available, can serve many purposes, without the credibility problems encountered in evaluating self-serving evidence. Perhaps most important, such evidence eases tremendously the concern that legal sanctions may intrude on economically desirable behavior; if the actor himself believes that he is seeking to prevail, not by means of greater efficiency, but by means of brute financial power or worse, a court may well accept that judgment. ${ }^{77}$ In addition, extrinsic evidence of

for trial); Scott Publishing Co. v. Columbia Basin Publishers, Inc., 293 F.2d 15 (9th Cir.), cert. denied, 268 U.S. 940 (1961); N.W. Controls, Inc. v. Outboard Marine Corp., 333 F. Supp. 495, 517 (D. Del. 1971); United States v. Jerrold Electronics Corp., 187 F. Supp. 545 (E.D. Pa. 1960), affd. per curiam, 365 U.S. 567 (1961); United Fruit Co., [19701973 Transfer Binder] TRAde REg. REP. If 20,209 (FTC. 1973).

75. See Parts V-VI infra.

76. See text accompanying note 2 supra.

77. A classic statement of this proposition is found in Judge Learned Hand's opinion in United States v. Corn Prods. Ref. Co., 234 F. 964, 978, 1012-14 (S.D.N.Y. 1916), appeal dismissed, 249 U.S. 621 (1919). Highly explicit and damning memoranda of purpose were made and preserved as business records. Such evidence of intent was found important as a demonstration that the low prices charged were not intended to be perpetuated as a result of efficiencies achieved but were meant to be transient weapons employed to eliminate competition.

It is, nonetheless, difficult to place much confidence in the excited prose often adopted by middle management in recommending action to fend off the inroads of competition. Very often focus on competitors is helpful only if a court is prepared to outlaw competitive actions that preserve or improve a market position on the ground that intent to accomplish that result is, without more, unlawful. See, e.g., Telex Corp. v. International Business Machs. Corp., 1973-2 Trade Cas. If 74,774 (N.D. Okla. 1973).

There may, further, be situations in which even the explicitly predatory purpose of the actor should not be enough to establish illegality, although these situations must be 
predatory intent may be useful in predicting the consequences of the accompanying conduct, ${ }^{78}$ both as a reflection of the presumably expert assessment of the actor who is immediately engaged in the market, $^{79}$ and as a suggestion that if the means employed are not successful additional means may be adopted.

c. Intent as evaluation of conduct. Proof of the intent that outlaws any given conduct as an attempt to monopolize is most often derived from proof of the conduct itself. If the wrongful intent is the intent to acquire monopoly power, or at least to restrain competition by improper means, proof of the means employed most often stands as proof of the intent as well. ${ }^{80}$ In many ways, the conclusion of improper intent is simply used to express an independent conclusion that, given a firm's level of market power, its behavior was sufficiently undesirable to be held unlawful. ${ }^{81}$

very rare. The most obvious illustrations are those of the intending predator who lacks any plausible means of accomplishing his wicked ends, and of the firm that mistakenly believes that its clearly efficiency-promoting conduct is undesirable.

78. In the attempt area, the original statement is Swift \& Co. v. United States, 196 U.S. 375, 396 (1905). See also, e.g., United States v. Reading Co., 226 U.S. 324, 370 (1912); Boone, Single-Corporation Competitive Torts and the Sherman Act: $A$ Projection Based Upon a Review of the Albert Pick, Atlantic Heel, and Perryton Cases, 2 GA. I. REv. 372, 375-76 (1968).

79. This expert judgment is implied both as to the power of the firm to accomplish its intended results and as to the nature of those results. See Rea v. Ford Motor Co., 1973-1 Trade Cas. I 74,332 (W.D. Pa. 1972); Boone, supra note 78, at 376.

80. There is an abundance of authority stating explicitly that intent must be shown by the acts of the defendant and the surrounding circumstances. One of the most carefully intentional statements is found in United States v. American Oil Co., 249 F. Supp. 799 (D.N.J. 1966), where the sufficiency of an indictment to charge the intent required for an attempt is approached on the principle that the indictment must charge the acts upon which the required intent may be found. See also, e.g., Independent Iron Works, Inc. v. United States Steel Corp., 322 F.2d 656, 667 (9th Cir.), cert. denied, 375 U.S. 922 (1963); Kansas City Star Co. v. United States, 240 F.2d 643, 650-51 (8th Cir.), cert. denied, 354 U.S. 923 (1957); McKeon Constr. Co. v. McClatchy Newspapers, 1970 Trade Cas. If 73,212 (N.D. Cal. 1969); Woods Exploration \& Producing Co. v. Aluminum Co. of America, 304 F. Supp. 845 (S.D. Tex. 1969), revd., 438 F.2d 1286 (5th Cir. 1971), cert. denied, 404 U.S. 1047 (1972) (instruction to jury quoted in ABA ANTITRUsT SECTION, supra note 34, at 83); Bergjans Farm Dairy Co. v. Sanitary Milk Producers, 241 F. Supp. 476 (E.D. Mo. 1965), affd., 368 F.2d 679 (8th Cir. 1966) (instruction to jury quoted in ABA ANTITRUST SEcTion, supra, at 84); United States v. Jerrold Electronics Corp., 187 F. Supp. 545, 567-68 (E.D. Pa. 1960), affd. per curiam, 365 U.S. 567 (1961); ABA ANTITRUST SECTION, ANTITRUST DEVELOPMENTS 1955-1968, at 37 (1968); Johnston, Monopolize or Attempt to Monopolize, in ABA ANTmRust Section, ProceEdings 72, 77 (1953).

In addition, there are, of course, opinions reflecting the general rule that what is required is not the intent to exclude competitors, but the intent to exclude them by improper means-as shown by the use of improper means. E.g., United States v. Kleaxflax Linen Looms, Inc., 63 F. Supp. 32, 39-41 (D. Minn. 1945).

81. Cf. Judge Wyzanski's observation that "there is no sharp distinction between (a) the existence of an intent to exclude and (b) the use of unfair means." Union Leader Corp. v. Newspapers of New England, Inc., 180 F. Supp. 125, 140 (D. Mass. 1959), affd. in part, 284 F.2d 582 (1st Cir. 1960), cert. denied, 365 U.S. 833 (1961). 
In short, the conclusion that the forbidden specific intent has been shown is often no more than an illustration of the common legal tendency to camouflage an uncertain evaluation of circumstances in epithetical words of improper motivation.

d. Summary evaluation of the specific intent requirement: Is it really necessary? Swift and many subsequent cases have instinctively adopted the specific intent requirement in an effort to confine attempts to behavior that closely approaches monopolizing behavior. If attempts are to be so confined, the function can be performed as effectively by the dangerous probability requirement. Dispensing with the specific intent requirement would help to avoid the range of practical and theoretical disadvantages that the requirement now entails.

The primary practical disadvantage of the specific intent requirement results directly from its usually fictive character. There is always a danger that courts will lose sight of the conclusional and inferential nature of the intent element and fall into undisciplined, though stimulating, speculation that, given the conduct and its market setting, legality should turn upon the fact-finding hunch as to motivation. ${ }^{82}$ Further, the formula may undesirably divert attention from the central task of assessing the legitimacy of the conduct involved within its market setting, rather than provoking a more thoughtful evaluation.

The first theoretical disadvantage is almost aesthetic in character. If unlawful monopolization can be accomplished by conduct that lacks any specific intent of acquiring monopoly power, why should not attempt doctrine be parallel? While very good reasons may exist for not finding an attempt to monopolize in all conduct that approaches unlawful monopolization, ${ }^{83}$ and while it may be convenient to clothe those reasons in the robes of specific intent, the result is at least an invitation to confusion.

The second disadvantage is more important. The contemporary challenge to current doctrine rests on the belief that courts should play an important role in evaluating the desirability of competitive behavior by firms whose market positions fall considerably short of individualized monopoly power. ${ }^{84}$ Courts should not answer this chal-

82. E.g., Alles Corp. v. Senco Prods., 329 F.2d 567, 572 (6th Cir. 1964): "The purpose or intent to create or maintain a monopoly transforms what might otherwise be a legal method of doing business into an illegal method under Section 2 ..." (reliance on section 2 is completely unnecessary to disposition of case); Blecher, supra note 2 , at 217 . 18.

83. See part $I(C)(3)(b)$ infra.

84. See Parts II-III infra. 
lenge by defaulting on the ground that any criminal attempt inherently requires specific intent. For instance, whatever may be said of Goodyear and Firestone, who respectively enjoy twenty-eight and twenty-five per cent shares of the replacement tire market, ${ }^{85}$ it does not seem at all probable that either of them can be charged with a specific intent to acquire single-firm monopoly power. The very question to be answered is whether courts can improve the replacement tire market by policing their behavior; the question is merely avoided by reliance on intent.

On the other hand, several practical advantages may be found in current specific intent formulations. All of these advantages, however, could be achieved as well or better by other means.

The most obvious advantage of current doctrine is that it clearly justifies reception of direct evidence of business motivation, whether exculpatory or condemnatory. The same evidence should be admissible under any approach that attempts an honest evaluation of business conduct.

A second advantage of current doctrine is that the need to brand business conduct with a derogatory conclusory label may operate as a deterrent to improvident decision. Faced with the requirement that conduct be found to be specifically aimed at improper acquisition of monopoly power, a judge or jury may evaluate the defendant's conduct more carefully than if the question of desirability were put more simply and directly. The same result could be reached with greater consistency between different cases by explicitly announcing a deliberate policy of reticence rather than by relying on an ad hoc psychological reaction to the "specific intent" label.

The least rational advantage of the specific intent formulation may be of considerable practical virtue. One of the great dangers of antitrust law is that the fear of prosecution and treble-damage liability may deter desirable competitive activity. It is possible that businesspersons who know that their hearts are pure and who believe that liability attaches only to wicked behavior will be more willing to engage in desirable behavior than if they believe that liability hinges on an ex post facto judicial evaluation of its legitimacy. Although it is difficult for a cautious lawyer to imagine any comfort in the obscurity of present attempt doctrine, this possible virtue cannot be rejected out of hand. Again, however, it seems likely that the same advantages could be achieved by an open avowal that courts will intrude only in very clear circumstances.

85. See text accompanying notes 4-6 supra. 
Finally, the greatest service of the specific intent requirement may be that it stands as an awkward symbol of a conclusion that the attempt category simply should not be applied to establish an offense by analogy to the most nearly innocent forms of unlawful monopolization. The same protection might be achieved more directly by further development of the relationship between market power and the conduct from which intent is normally inferred.

In sum, it would be desirable to relegate the role of intent to consideration of extrinsic evidence of actual motivation as one element in assessing the conduct before the court. Any need for confining attempts to a close proximity to monopolization can be better served by care in evaluating the combined elements of conduct and market power. ${ }^{86}$

\section{Conduct Without Monopolization}

Examination of the specific intent requirement has revealed that attempt analysis is basically centered on an evaluation of competitive behavior. Most of the problems encountered by efforts at such evaluation will be explored by examining the expansive contention that it should be undertaken and liability should often be found in situations where there is no dangerous probability of completing a monopolization offense. 87 In evaluating competitive behavior, market power plays a role that goes far beyond its obvious role in making the dangerous probability determination.

a. Market power as a measure of conduct. Market power is a vitally important ingredient of any effort to assess the competitive desirability of business behavior. The implications of descriptively identical conduct may depend heavily on the actor's market position, since market position affects the consequences of the behavior and since it may also bear on the desirability of those consequences. For example, a deliberate below-cost pricing policy, adopted to expand the firm's market share, seems quite different when it is undertaken by a pigmy facing giants than when it is undertaken by a giant facing pigmies. ${ }^{88}$

86. A rather different formulation of reasons for dispensing with current specific intent formulations is found in Hawk, Attempts to Monopolize-Specific Intent as Antitrust's Ghost in the Machine, 58 CORNELL L. REv. 1121 (1973).

87. The problems encountered in evaluating competitive behavior are discussed in Parts V-VI infra.

88. See, e.g., Morning Pioneer, Inc. v. Bismark Tribune Co., 1972 Trade Cas. \ 74,169 (D.N.D. 1972) (conduct that might be permissible if indulged in by the weaker of two rivals was so "heavy-handed" as to be an attempt to monopolize when indulged in by the dominant firm); Cape Cod Food Prods., Inc. v. National Cranberry Assn,, 119 F. Supp. 900, 908 (D. Mass. 1954) (jury charged that an increasing market share "may 
In addition to this critical function, market power may make a pair of useful negative contributions to judicial evaluation of competitive behavior. At the high power end of the spectrum, doubts about the effects of the conduct in its market setting can be more readily resolved against the suspect actor, simply because it is less important to ensure a wide latitude of competitive tactics to firms already enjoying considerable market power and competitive success. At the low power end of the spectrum, on the other hand, it may be possible to dispose easily of cases involving otherwise dubious conduct on the combined grounds that where evaluation is difficult courts should intrude only if there is predatory intent and that predatory intent is highly unlikely in a setting of low market power. ${ }^{89}$

b. High market power and innocent behavior. The relationship of market conduct to market power suggests a continuum of offensive

invite much more careful scrutiny than a small" share); Levi, The Antitrust Laws and Monopoly, 14 U. CHr. L. Rev. 153, $159-60$ (1947).

A characteristically lucid statement is provided in Turner, supra note 25, at 314-15: It is necessary to examine the economic context in which the conduct takes place to determine whether the restrictive effects outweigh the benefits. And typically the restrictive effects will vary directly with the market power of the firm involved. In short, in an attempt to determine the legality of monopoly power by assessing conduct, one tends to end up again with questions of power, and an attendant lack of clear standards.

More recently, however, a rather different statement has beeh provided: "Exclusionary behavior without adequate business justification may . . . be deemed an unlawful 'attempt' to monopolize under section 2. I will concede the possibility that market power may be an essential ingredient in determining the propriety of some kinds of conduct which may have a business justification." Turner, supra note 53, at 1228-29.

Earlier statements of the same idea can be found in Jones, Historical Development of the Law of Business Competition, 36 YaLE L.J. 207, 225 (1926); Kales, supra note 50, at 832 .

89. E.g., United States v. Singer Mfg. Co., 205 F. Supp. 394, $431-32$ (S.D.N.Y. 1962), revd. on other grounds, 374 U.S. 174 (1963); Blecher, Attempt To Monopolize Under Section 2 of the Sherman Act: "Dangerous Probability" of Monopolization Within the "Relevant Market," 38 GEo. WASH. L. REv. 215 (1969); Note, Prosecutions for Attempts to Monopolize: The Relevance of the Relevant Market, 42 N.X.U. L. REv. 110, 119 (1967). A highly similar notion is relied upon in United States v. Jerrold Electronics Corp., 187 F. Supp. 545, 567-68 (E.D. Pa. 1960), affd. per curiam, 365 U.S. 567 (1961), in concluding that it is unlikely that a small company would deliberately attempt to eliminate financially far more powerful companies by predatory means. And even a court that concluded that there is no need to demonstrate a dangerous probability of monopolization has thought it necessary to find a specific intent to acquire control of a relevant market, apparently on the theory that, given the intent, it is dangerously probable that some untoward consequences will result. See Bowl America Inc. v. Fair Lanes, Inc., 299 F. Supp. 1080, 1093 (D. Md. 1969) (among the factors relied upon in concluding that there was an intent to acquire a monopoly was that the defendant's market share was increased by its acquisitions to a level of 67 per cent in the most prominent of the markets considered).

A converse argument has also been advanced that attempt liability should be imposed on firms with dangerous levels of "economic," rather than market, power. See Note, Attempt to Monopolize Under the Sherman Act: Defendant's Market Power as a Requisite to a Prima Facie Case, 73 ColUM. L. REv. 1451, 1474-75 (1973). 
behavior-conduct relationships..$^{90}$ But judicial opinions seem to imply that courts will not distinguish between varying levels of monopoly power in evaluating a firm's conduct. If a firm is found to have monopoly power, that power must be outlawed if, for instance, the firm has engaged in restrictive practices like those employed in the United Shoe case, ${ }^{01}$ or has committed the even more vaguely exclusionary $A l c o a^{92}$ sin of expanding with a growing market.

The logic of current attempt doctrine, set against this background of monopolization law, suggests clearly that an attempt should be found if a firm is rapidly approaching monopoly power and is utilizing any tactic that would outlaw achieved monopoly power. ${ }^{03}$ This finding would be supported not only by the fact of a dangerous approach to monopolization but also by the demonstration that, even in other circumstances, "specific intent" refers primarily to the intent to engage in the conduct found unduly threatening to competition on the merits.

The shortcomings of this conclusion, however, are manifest. One way of emphasizing them is to consider the United Shoe opinion. The leasing practices that were found to make unlawful the position of attained monopoly power in the shoe machinery market were found not to be an attempt to monopolize when used in the tanning equipment market, in which the company had what was assumed to be a forty-three per cent share. ${ }^{94}$ If the worst that can be said is that the lease terms have an abstract tendency to make competitive entry and success more difficult, and if it is entirely possible that they entail significant benefits for the shoe-manufacturer lessees, how is a court to justify intrusion at any point short of monopoly? And if, analogizing to Alcoa, one of the greatest benefits of competition is to induce individual firms to risk expansion of capacity in anticipation of expanded demand, how is a court to justify curtailment of expansion before monopoly power is attained?

90. See, e.g., Telex Corp. v. International Business Machs. Corp., 1973-2 Trade Cas. I 74,774, at 95,439 (N.D. Okla. 1973): "[T] he precise boundaries of relevant markets and the likelihood of success in and of themselves become less important in attempt to monopolize cases as aggressive predatory intent and conduct emerge more clearly."

91. United States v. United Shoe Mach. Corp., 110 F. Supp. 295 (D. Mass. 1953), affd. per curiam, 347 U.S. 521 (1954).

92. United States v. Aluminum Co. of America, 148 F.2d 416 (2d Cir. 1945).

93. This problem is stated in poignant terms, by way of questions, in P. AREEDA, antrtrust Analysis, Problems, Text, Cases 174-76 (1967).

94. See $110 \mathrm{~F}$. Supp. at 338,346 .

95. This question is not meant to imply endorsement of the rationale for decision in Alcoa. Indeed, the diffculty with understanding the conclusion that it is unlawfully exclusionary to maintain a position of monopoly power by growing with the market 
One answer available under current attempt doctrine is suggested above: The unwillingness of courts to interfere with the most nearly innocent sorts of behavior until monopoly power has been achieved may be expressed in the conclusion that the firm lacks a wrongful "specific intent." The same protection might be achieved in other ways, with a substantial saving in conceptual tidiness. Most promising would be a direct avowal that the same forms of behavior that may justify interference with a very high level of market power simply cannot be extended backward by analogy to lesser levels of market power. Measurement of market power is too uncertain to justify appraisal of such conduct in settings that seem, at most, to involve a "dangerous probability" of monopoly power. Alternatively, courts might simply recognize that their ability to forecast ripening of the dangerous probability into monopoly power is not sufficient to justify intervention when the conduct is potentially beneficial.

c. Misuse of monopoly power. The Supreme Court has occasionally characterized the use of established monopoly power to limit competition as an attempt to monopolize. Brief examination of the leading cases reveals that no independent force need be attached to attempt analysis in such situations. The problem is one of misuse of monopoly power; recognizing the problem in these terms would make it possible to control the behavior of indissolvable monopoly even when it does not threaten to limit competition.

The first case is United States $v$. Griffith. ${ }^{96}$ The defendants were a group of affiliated corporations that owned motion picture theaters in many towns; the theaters faced competition in some of the towns but were without competition in sixty-two per cent of the towns at the end of the period involved. The defendants had undertaken combined dealings with motion picture distributors so that the purchasing power derived from monopoly status in the "closed" towns could be used to secure advantageous exhibition privileges in the towns where they faced competition. The Supreme Court found this activity to be a conspiracy in violation of both sections 1 and 2 of the Sherman Act. Despite sporadic references to attempt doctrine, ${ }^{97}$ the more interesting dicta characterized such use of buying power as "a misuse

is the primary justification for reading the opinion as support for the argument that any persisting monopoly position should be found unlawful unless there are demonstrable losses in dissolving it. The effort to create an attempt offense cognate to that sort of monopolization offense hardly seems worthwhile.

96. 334 U.S. 100 (1948).

97. 334 U.S. at 105-06. 
of monopoly power under the Sherman Act"08 and stated that "the use of monopoly power, however lawfully acquired, to foreclose competition, to gain a competitive advantage, or to destroy a competitor, is unlawful."'9g

Several years later, Lorain Journal Co. $v$. United States ${ }^{100}$ was explicitly decided in terms of attempt doctrine. In this case the defendant published the only daily newspaper in Lorain, Ohio, and thereby enjoyed a "substantial monopoly in Lorain of the mass dissemination of news and advertising, both of a local and national character."101 After a radio station was established in nearby Elyria, the Lorain Journal refused to accept advertising from any Lorain merchant who advertised over the radio station. The deliberate purpose of this refusal was to destroy the radio station completely; the weapon chosen was highly dangerous, since many local merchants felt that they had to advertise in the local newspaper. The legal conclusion was that "a single newspaper, already enjoying a substantial monopoly in its area, violates the 'attempt to monopolize' clause of $\S 2$ when it uses its monopoly to destroy threatened competition."102 Although it is not clear, it seems apparent that the primary reason for resorting to attempt terminology was that the radio station had not yet been eliminated. ${ }^{103}$

Much more recently, attempt language was used in Otter Tail Power Co. v. United States. ${ }^{104}$ Otter Tail enjoyed exclusive franchise agreements for the retail distribution of electricity in many small towns and, in addition, possessed the only subtransmission lines available for carrying electricity to several of those towns. As the franchises expired, some of the towns sought to create municipal distribution systems; Otter Tail refused requests that it sell power to them at wholesale or deliver, over its own subtransmission lines,

98. 334 U.S. at 108.

99. 334 U.S. at 107.

100. 342 U.S. 143 (1951).

101. 342 U.S. at 147 .

102. 342 U.S. at 154.

103. In part, at least, the Court may have created its own difficulty by defining the market broadly as the mass dissemination of news and advertising. There would be ample justification for treating the local newspaper sphere as a market unto itself, thoroughly monopolized by the Journal. Even if the Journal could not be found to have monopoly power in the broader market discussed by the Court, misuse of its newspaper monopoly power to curtail competition in the broader market is ample basis for finding a violation. This basis for decision would have the added advantage of supporting intervention even where it could not be found that there was a dangerous probability of attaining monopoly power in the broader market.

104. 410 U.S. 366 (1973). 
power to be purchased by the towns from other sources. ${ }^{105}$ The Court, drawing from both the Griffith and the Lorain Journal decisions and relying on the finding that the dominance in transmission facilities had been used to foreclose competition in retail distribution, concluded that the use of monopoly power to destroy threatened competition is an unlawful attempt to monopolize. ${ }^{106}$

Although attempt language figures in all three opinions, there is no reason why courts should outlaw such uses of monopoly power only in situations that involve a specific intent to monopolize and a dangerous probability of success. At a minimum, unlawful monopolization should be found when a firm holding monopoly power in one market uses that power to achieve a competitive advantage in another market. ${ }^{107}$ This formulation would cover all three cases and would justify judicial intervention in many situations in which dissolution of the monopoly power is thought undesirable..$^{108}$

These opinions could also support the broader conclusion that a firm holding monopoly power in one market may not use that power to distort competition in any market, whether or not it competes in that market. The Lorain Journal case may provide a convincing illustration of the advantages of this formulation. Suppose that the Journal had refused, for motives of spite, to accept advertising from one of two competing department stores in town. ${ }^{109}$ Although it may be difficult to find an attempt to monopolize a department store market in which the newspaper has no competitive interest, ${ }^{110}$ a court should not hesitate to find that the use of monopoly power held in

105. It was also charged that Otter Tail had resorted to litigation designed to prevent the issuance of municipal bonds to finance local distribution systems. There was a further charge, of only incidental significance, that it had relied on ambiguous provisions in transmission contracts with several other power suppliers to "justify" its refusal to transmit power from such suppliers to the municipalities.

106. 410 U.S. at 377.

107. For a cogent argument that the "Griffith misuse-of-monopoly" theory should be recognized "as a unique offense under Section 2," see Hawk, supra note 86, at 1156-62.

108. The difficulties of dissolving the only newspaper in a small town or of requiring the creation of duplicate electrical transmission facilities in sparsely settled areas are apparent. It is much easier to dissolve common ownership of motion picture theater monopolies in several towns; nonetheless, dissolution was found not warranted on remand of the Griffith case. United States v. Griffith Amusement Co., 94 F. Supp. 747 (W.D. Okla. 1950).

109. Professor Areeda asks this question in terms of a refusal to accept advertising from merchants in nearby towns. P. AREEDA, supra note 93 , at 119 . If the motive were local chauvinism, the case is no easier than the case of spite motivation. If there were instead some element of self-service, as from a belief that loss of local business might impair local advertising revenues more extensively than it might augment nonlocal revenues, the case might seem closer to the existing law.

110. $C$ f. text accompanying notes 178-79 infra. 
one market to distort competition in another market is an unlawful monopolization.

Section 2 might be used for an even broader regulation of monopolists' behavior. Courts may be able to identify and regulate some undesirable uses of monopoly power without catapulting into the unmanageable task of regulating monopoly pricing.

No effort will be made to define or even identify the situations in which it may prove desirable to effect some added measure of judicial control. But one possibility is suggested by a recent case involving a local major-league professional football monopolist. ${ }^{111}$ Regular-season ticket holders were required to purchase exhibitionseason tickets in order to preserve their seat preferences. The plaintiffs claimed that this practice involved an unlawful tie of exhibitionseason tickets to regular-season tickets. The court responded that even if separate products are involved, tying is no more a violation than any other means of monopoly pricing. It would have been better to face the "two products" question squarely; if two products really are involved, tying by a monopolist should be found unlawful precisely because it is often a more effective means of exploiting the monopoly position than is simply manipulating the price of the more desirable product..112

Adopting the broadest formulation of misuse of monopoly power has an incidental advantage. The two-market perspective suggests that courts should seek to control refusals by a monopolist engaged at one level of a productive stream to deal with distributors engaged in distributive "markets" further down the stream by treating the refusal as an attempt to monopolize the subsequent distributive market. ${ }^{113}$ If courts should control such behavior in some situations, ${ }^{114}$ analysis in terms of misuse of monopoly power can readily achieve that result. As compared to the two-market perspective, the advantage would be that courts would not be trapped into an often artificial pretense that once separate stages of distributing a single product must always be identified as two markets.

The uncertainty of the choice between attempt and monopoliza-

111. Grossman Dev., Co. v. Detroit Lions, Inc., 1973-2 Trade Cas. $\$ 74,790$ (E.D. Mich. 1973).

112. See, e.g., Bowman, Tying Arrangements and the Leverage Problem, 67 YALE L.J. 19 (1957); Burstein, $A$ Theory of Full Line Forcing, 55 Nw. U. L. REv. 62 (1960); Markovits, Tie-ins, Reciprocity, and the Leverage Theory, 76 YALE L.J. 1397 (1967); Markovits, Tie-ins, Reciprocity, and the Leverage Theory Part II: Tie-ins, Leverage and the American Antitrust Laws, 80 YALE L.J. 195 (1970).

113. See Hawk, supra note 86, at 1159-64.

114. See Parts V-VI infra. 
tion theories for these cases provides a small illustration of a final concern with current attempt doctrine. For upon reflection, it may be discovered that there is really no satisfactory line at all between the concepts of monopolization and attempts to monopolize.

\section{The Illusion of Attempts Cognate to a Judge-Made Offense of Monopolization}

There is nothing startling about the proposition that the specific intent requirement often represents little more than a judicial evaluation of the desirability of the challenged competitive conduct in its entire market setting, including an evaluation of the actor's power. This proposition suggests that courts are engaged in the familiar task of determining whether conduct that does not quite meet all the requirements of a completed offense has nonetheless run sufficiently afoul of the policies and purposes underlying the completed offense to warrant punishment as an attempt.

The peculiarity of assigning this role to attempt analysis under section 2 of the Sherman Act, however, is that judges themselves have developed the purposes and policies attributed to the prohibition of monopolization and have translated those purposes and policies into such definition as there may be of the completed monopolization offense. ${ }^{115}$ If it can be concluded that challenged conduct-in light of its nature, the power of the actor, and the over-all market settingruns afoul of the policies of section 2 , there is no intrinsic reason why the conclusion may not be as readily formulated in terms of monopolization as in terms of attempted monopolization.

One example may illustrate this premise. It was pointed out earlier that courts have been unwilling to find that actual exclusion of a competitor is, without more, an attempt to monopolize. ${ }^{116}$ It was further noted that this conclusion seems strangely at variance with the traditional statements that monopoly power is the power to control prices or eliminate competition. The same point may now be recast differently. If actual exclusion of a competitor should be found unlawful, for whatever reason, adopting the conclusory terminology of attempt rather than the conclusory terminology of monopolization offers no intrinsic advantage. ${ }^{117}$

115. The lack of substantial Congressional guidance is briefly explored in Part IV(C) infra.

116. See text accompanying note 44 supra.

117. It has already been urged that the exclusion of any competitor by undesirable means is itself the offense of monopolization, demonstrating sufficient power to run afoul of section 2. See Adelman \& Brooks, The Integrity of the Administrative Process, Sherman Section 2 and Per Se Rules-Lessons of Fraud on the Patent Office, 19 WAXNE L. REv. I (1972); Smith, supra note 33, at 237-38. 
The effort in most current decisions to retain a close relationship between attempt and monopolization may represent an inarticulate reaction to this perception. The statute contains a specific attempt offense, so it is necessary to give some meaning to it; the natural ploy is to assign to the attempt category the least troublesome conduct that might, instead, have been characterized as monopolization..$^{118}$

Explicit recognition that attempts simply represent an arbitrarily segregated category of single-firm behavior that runs afoul of the basic purposes of the section 2 prohibition of monopolization would have the advantage of demythifying the requirements of specific intent and dangerous probability. In addition, recognition that present attempt doctrine is an essentially arbitrary appendage of monopolization would help in approaching the contemporary challenge that the category of attempts should be expanded, for, in a real sense, the challenge rests on a claim that the attempt offense should be redefined in its own terms, independent of any relation to the concerns embraced by monopolization law. Attention can now be turned to that claim.

\section{Need To Expand Section Two}

Although not cast explicitly in such terms, the primary goal of current efforts to expand the category of attempts to monopolize is to create a self-contained competitive wrong independent of any direct relationship to monopolization. The primary need for expansion is found in an asserted need to extend the means of judicial control of single-firm behavior; secondary needs are often seen in the call for a stronger legal response to the problems of oligopoly and in the more general defects of section 1 . Some of these needs may be real; after exploring them briefly, it will be suggested that monopolization doctrine can meet them better than attempt doctrine.

\section{A. Control of Single-Firm Behavior}

It is not difficult to be offended, or even outraged, by single-firm competitive behavior that does not present any probability, dangerous or otherwise, that the actor will acquire monopoly power. Such behavior might be left to regulation by state unfair competition law, supplemented by enforcement of the Federal Trade Commission Act. ${ }^{119}$ Many observers have felt that these controls are inadequate and have suggested an expansion of antitrust remedies. Perhaps because its amorphous nature permits easy reshaping, a wide variety of

118. Cf. P. AREEDA, supra note 93 , at 176.

119. 15 U.S.C. $\$ \S 41-58$ (1970). 
arguments have been advanced that the attempt to monopolize offense should be developed as a primary means of control.

Professor Turner is very much responsible for providing the modern justification for this approach in his highly influential article on monopolization and market definition. ${ }^{120}$ Arguing that Supreme Court precedent does not require or support any measurement of market power in attempt cases, he concludes that "unreasonable specific intent is itself" the offense of attempted monopolization:121

The kind of conduct that typically establishes the requisite "specific intent" in attempt and conspiracy cases is clearly conduct which has no social or economic justification. No benefits can be expected, at least in the long run, from predatory pricecutting, coercive refusal to sell, and similar abuses of economic power. If defendants are attempting to drive someone out of the market by foul means rather than fair, there is ample warrant for not resorting to any refined analysis as to whether the intent is to drive everyone out or whether, having taken over all of the production of a particular commodity, the defendants would still face effective competition from substitutes. Coercive conduct is analogous to price fixing . . . . [In] the typical attempt or conspiracy case, ... one may readily infer that the principal goal is aggrandizement unmerited by superiority in product or technique .... It is reasonable to discard any refined concept of market in attempt and conspiracy cases because the conduct involved is so egregious that it may be appropriately condemned per se. ${ }^{\mathbf{1 2 2}}$

More recent writers, ${ }^{123}$ following this lead, have likewise concluded that vicious single-firm behavior requires a remedy and that, at most, relevant market analysis is useful in determining the probable intent or competitive impact of an apparently vicious actor. This

120. Turner, supra note 25.

121. Id. at $294-95$ n. 44 .

122. Id. at 305-07.

123. E.g., Blecher, supra note 89; Note, Prosecutions For Attempts To Monopolize: The Relevance of the Relevant Market, 42 N.Y.U. L. REv, 110 (1967); Note, Attempt to Monopolize: The Offense Redefined, 1969 UTAH L. REv. 704.

A related suggestion is that the scope of the relevant market should be defined more narrowly as the nature of the defendant's behavior becomes more vicious. See, e.g., Boone, supra note 78, at 375-76. Cf. the protest of this tendency in Hibner, supra note 37 , at 168.

A final possibility is that the relevant market requirement will be retained in name only. In Woods Exploration \& Producing Co. v. Aluminum Co. of America, 438 F.2d 1286 (5th Cir. 1971), cert. denied, 404 U.S. 1047 (1972), for instance, the market was defined for purposes of monopolization claims as a single gas-producing field. There was no hint of inquiry into whether control of production from that field would give any trace of power in the market for selling its products; attention was instead directed to the ability to control access by potential competitors to production in that particular area. This approach amounts to a change of emphasis in the values to be protected by section 2 closely akin to the changes that would result from ignoring market definition matters entirely. 
view has also been adopted and asserted by the Antitrust Division of the Department of Justice. ${ }^{124}$

The critical assumption of these arguments is that courts are able to identify the categories of "coercive conduct" that are "so egregious that [they] may appropriately be condemned per se." This assumption will be examined in Part $V$ below.

\section{B. Control of Oligopoly}

Whether courts ought to outlaw as such oligopoly structure and its inevitable invitation to noncompetitive behavior continues to present the single most important, and most difficult, of all antitrust questions. Those who are anxious to find a means of attacking oligopoly structure have at times suggested that oligopoly is inherently conspiratorial ${ }^{125}$ or that firms in an oligopoly market are individually guilty of monopolization. ${ }^{126}$ In addition, it is sometimes urged that firms in an oligopoly market should be held for attempting to monopolize. ${ }^{127}$ Presumably attempt doctrine is attractive because it

124. See Memorandum for United States as Amicus Curiae at 10-11, Hiland Dairy, Inc. v. Kroger Co., 395 U.S. 961 (1969), denying cert. to 402 F.2d 968 (8th Cir. 1968). The Director of Policy Planning of the Antitrust Division clearly stated his views in 1972: 'To eliminate the 'dangerous probability' and 'market' requirements from Section 2 attempt to monopolize cases would make it a much more effective tool for dealing with indefensible single firm conduct." Baker, Section 2 Enforcement-The View From the Trench, 41 A.B.A. ANTrirust L.J. 613, 620 (1972). In addition, see the recital of the Government's argument in United States v. Chas. Pfizer \& Co., 245 F. Supp. 737 (E.D.N.Y. 1965)

There may be a touch of poetic justice in the fact that rone of the early antitrust opinions of Judge McLaren, recently Assistant Attorney General in charge of the Antitrust Division, continued the requirement that relevant market and dangerous probability be shown. See Radzik v. Chicagoland Recreational Vehicle Dealers Assn., 1972 Trade Cas. If 74,167 (N.D. Ill. 1972). In rather strange contrast, Judge McLaren had testified as Assistant Attorney General that predatory competition by a manufacturer with its own distributors might be subject to challenge as an attempt to monopolize. BNA ANTITRUst \& TRADE REG. REP., March 17, 1970, at X-1 to -3. Under this view courts might well dispense with any relevant market/dangerous probability inquiry. $C f$. Industrial Bldg. Materials, Inc. v. Interchemical Corp., 437 F.2d 1336, 1342 (9th Cir. 1971).

125. E.g., Levi, supra note 88, at 177; Rostow, supra note 49, at 783-84. The basic argument that interdependent behavior intrinsically involves sufficient agreement to fall within the antitrust laws is elaborated in Turner, The Definition of Agreement Under the Sherman Act: Conscious Parallelism and Refusals To Deal, 75 HaRv. L. REv. 655 (1962). Cf. Posner, Oligopoly and the Antitrust Laws: A Suggested Approach, 21 STAN. L. REv. 1562 (1969).

126. Bowman, Toward Less Monopoly, 101 U. PA. L. Rev. 577 (1953); Levy, Some Thoughts on "Antitrust Policy" and the Antitrust Community, 45 MiNn. L. REv. 963, 980-82 (1961); Marcus, Antitrust Bugbears: Substitute Products-Oligopoly, 105 U. PA. L. REv. 185 (1956); McConough \& Winslow, The Motion Picture Industry: United States v. Oligopoly, I STAN. L. REv. 385 (1949); Turner, supra note 53, at 1229-31. Cf. Note, Oligopolies, Cereals, and Section Five of the Federal Trade Commission Act, 61 Gro. L.J. 1145,1169 n.181 (1973).

127. E.g., Levi, supra note 88, at 177; Stocking, The Rule of Reason, Workable 
provides the easiest path around the doctrinal limitations that have stalled any effort to use monopolization or conspiracy theories.

Although the challengers have offered persuasive arguments, it is terribly difficult to be certain that their arguments justify the adoption of doctrines that would effectively outlaw the structure of much of our industry. ${ }^{128}$ It may be much less dangerous to create a remedy for some forms of oligopoly conduct (rather than for oligopoly structure), including conduct by a single firm that, because it is not imitated by others, cannot be reached through section 1 under any definition of contract, combination, or conspiracy. The example of externally documented predation by a small member of a tight oligopoly, set out in the Introduction, ${ }^{129}$ is one that most observers would agree justifies an antitrust remedy.

It is more important to determine carefully whether courts should expand their control of oligopoly structure or behavior at all than to choose carefully among available legal theories. If the decision to expand control is reached, however, it will be suggested below that monopolization doctrine is better suited to the task than attempt doctrine.

\section{Repair of Section One}

Expansion of section 2 might be used to alleviate several problems caused by the inadequacy of section 1 as a means of controlling what is essentially single-firm behavior. "Conspiracy" and "combination" doctrine have been used to prohibit intraenterprise conspiracy and to punish firms coerced to participate in a conspiracy, at the cost of announcing doctrine capable of prohibiting much desirable conduct. Courts are only beginning to feel confident of their ability to extend section 1 to protect victims injured by their own refusal to join a conspiracy. And no doctrine is yet available to reach firms that solicit others to join a conspiracy without apparent success.

Intraenterprise conspiracy doctrine purports to apply the full sweep of the section 1 controls of agreements between competitors to

Competition, and Monopoly, 64 YalE L.J. 1107, 1161 (1955); Turner, supra note 53, at 1229-31; Turner, supra note 125, at 682-83.

This possible use of attempt doctrine has also been rejected. See Johnston \& Stevens, Monopoly or Monopolization-A Reply to Professor Rostow, 44 IIL. L. REv. 269, 290 (1949).

128. One possible method of limiting the sweep of an attack on oligopoly is to develop a new statute. The model for much of the current discussion is the Concentrated Industries Act proposed by the White House Task Force on Antitrust Policy in 1968. See Report of the White House Task Force on Antitrust Policy [The Neal Report], i J. REPRINTS FOR ANTITRUST L. \& ECON. 631, 649-72, 713-33 (1969).

129. See text accompanying notes $2-3$ supra. 
agreements between technically separate entities, even though the entities are as unified as a single corporation under any rational test of realistic control and financial unity. This doctrine probably results from a desire to prohibit single-firm behavior that courts have felt unable to reach under section $2 .{ }^{130}$ Expansion of section 2 would free courts to abandon the conspiracy doctrine. The result might be more control of single-firm behavior; it might be less. Whichever result occurs, it would at least be reached on defensible grounds rather than on the accident of form. ${ }^{131}$

It is frequently ruled that coercion to join a conspiracy is no defense. ${ }^{132}$ Accordingly, it is quite possible that liability could be

130. Present doctrine clearly creates the possibility that the legality of identical activity may turn on the choice of organizational forms. Organization of a single enterprise along lines of divisions (or less formal groupings) within a single corporation precludes the plurality needed to form a combination or conspiracy, while organization through wholly owned subsidiaries makes combination and conspiracy possible. There is no satisfactory explanation available to defend this possibility; the most that can be said is that the doctrine is seldom invoked, and then primarily as a means of reaching behavior that enforcers would prefer to reach as single-firm behavior. See, e.g., Interview, supra note 11, at 122-23. Justification for a considerably more restricted application of conspiracy doctrine to very closely related corporations is asserted in Willis \& Pitofsky, Antitrust Consequences of Using Corporate Subsidiaries, 43 N.Y.U. L. REV. 20 (1968), where current doctrine is carefully examined.

For a brief time, it appeared that the senselessness of the distinction between different forms of organization might lead to a rule that a corporation organized into divisions may conspire with itself. This possibility has at least temporarily been put to rest. See Hawaiian Oke \& Liquors, Ltd. v. Joseph E. Seagram \& Sons, Inc., 272 F. Supp. 915 (D. Hawaii 1967), revd., 416 F.2d 7I (9th Cir. 1969), cert, denied, 396 U.S. 1062 (1970).

131. The desire to substitute a coherent doctrine of single-firm behavior for artificial conspiracy doctrine is not new. See Rahl, Conspiracy and the Anti-trust Laws, 44 IL.L. L. REv. 743, 767-68 (1950). Cf. Boone, Single-Corporation Competitive Torts and the Sherman Act: A Projection Based upon a Review of the Albert Pick, Atlantic Heel, and Perryton Cases, 2 GA. L. Rev. 372 (1968).

Expansion of attempt doctrine would doubtless augment the present tendency, sec text accompanying note 300 infra, to add an attempt claim to private litigation pursuing claims that rest essentially on conduct meeting any test of combination or conspiracy. Such ready reference to attempt doctrine may cause difficulties under current doctrine because it opens up added issues of intent and market power; under an expanded doctrine, addition of attempt claims would likely make little difference either way in such cases and might even help avoid some occasionally difficult problems of establishing the combination or conspiracy.

132. E.g., Otto Milk Co. v. United Dairy Farmers Cooperative Assn., 388 F.2d 789, 797 (3d Cir. 1967); Flintkote Co. v. Lysfjord, 246 F.2d 368, 375-76 (9th Cir.), cert. denied, 355 U.S. 835 (1957); England v. Pan Am. World Airways, Inc., 1970 Trade Cas. I 73,205 (S.D.N.Y. 1970); Commonwealth Edison Co. v. Allis-Chalmers Mfg. Co., 245 F. Supp. 889, 892 n.6 (N.D. Ill. 1965).

The Supreme Court has expressly left the question open. See First Natl. Bank v. Cities Service Co., 391 U.S. 253, 280 n.16 (1968). However, in Webb v. Bladen, 480 F.2d 306 (4th Cir. 1973), the court, in order to find a union immune from antitrust liability because of lack of conspiracy, found that it had acted alone, without conspiring with general contractors, when it forced the general contractors to terminate dealings with a masonry contractor against the generals' will. Very faint support for allowing a coercion defense may be found in dictum in McHugh v. United States, 230 F.2d 252, 254 (Ist Gir.), cert. denied, 951 U.S. 966 (1956). 
imposed on such hapless victims as the local merchants in the Lorain Journal case, who were compelled to boycott a new radio station because the established local newspaper monopolist refused to carry advertising of any firm that advertised over the radio station. ${ }^{133}$ If there were greater confidence in single-firm control doctrine, some further evolution might occur in the doctrines concerning firms coerced to participate in collective activity against their own desires, at least where they receive no benefit from participation.

Conversely, courts have long felt awkward about allowing a firm to recover damages when its virtuous refusal to enter into an illegal arrangement has prevented the creation of a combination or conspiracy. ${ }^{134}$ Although they are increasingly ruling-despite the conceptual difficulties-that recovery should be available, ${ }^{135}$ reliance on an expanded section 2 could provide an easy alternate solution.

The difficulty of establishing combination or conspiracy may counsel reliance on section 2 in another context as well. Whether or not an offense should be found.in cases of clearly unsuccessful solicitation to join a conspiracy, it can be extremely difficult to establish success or failure. Imagine, for instance, a suggestion by one firm to its rival that they both raise prices from $\$ 9.00$ to $\$ 10.00$, met by an immediate rejection; the next week, one firm sells at $\$ 10.05$, and the other at $\$ 9.95$. Similar difficulties in demonstrating that any particular purchasing pattern has resulted from, or even been influenced by, informal reciprocity invitations or formal reciprocity pressures probably underlie the alternative reliance on attempt doctrine in the Department of Justice attacks on reciprocity. ${ }^{136}$

Although real, these incidental benefits with respect to relieving section I do not of themselves provide great independent support for expanding section 2 . If the case is to be made, it must rest primarily on the need for greater regulation of single-firm competitive behavior as such.

\section{Expansion of Monopolization or of Attempts?}

The primary advantage of expanding the reach of the attempt offense is that the expansion can be accomplished without doing vio-

133. The case is Lorain Journal Co. v. United States, 342 U.S. 143 (1951). The argument for finding agreement is detailed in Turner, supra note 125, at 702-03. Cf. Otto Milk Co. v. United Dairy Farmers Cooperative Assn., 388 F.2d 789, 797 (3d Cir. 1967).

134. See, e.g., Quinn v. Mobil Oil Co., 375 F.2d 273 (1st Cir. 1967). Cf. Albrecht v. Herald Co., 390 U.S. I45, 162 (1968) (Harlan, J., dissenting).

135. E.g., Cornwell Quality Tools Co. v. C.T.S. Co., 446 F.2d 825, 831-32 (9th Cir. 1971), cert. denied, 404 U.S. 1049 (1972); Osborn v. Sinclair Ref. Co., 324 F.2d 566 (4th Cir. 1963).

136. See text accompanying note 9 supra; text accompanying notes 296-97 infra. 
lence to any deeply entrenched doctrine. It will be shown below ${ }^{187}$ that substantial authority from the early years of the Sherman Act can be found for dispensing with any requirement of a close approach to the levels of market power that are now called monopoly power. On the other hand, elimination of the monopoly power requirement that the Supreme Court has clearly and repeatedly read into the monopolization offense would require the overruling of many decisions.

The ease of expanding the attempt category, paradoxically, affords the primary disadvantage of choosing that route. Once the obligation of close reference to monopolization doctrine has been put aside, there is little to restrain the extension of judicial control. The significance of the danger depends on a determination whether triers of fact may be misled into condemning as "unfair" or "coercive" some of the harsh but necessary acts of competition, which provide the benefits that supposedly result from survival of the competitively fit and death of the competitively weak.

It will be suggested below that the dangers in open-ended judicial evaluation of competitive behavior are indeed grave. ${ }^{138}$ Nevertheless, the room for further extension of judicial control over some forms of untoward single-firm behavior must be recognized. Redefinition of the monopolization offense may provide a suitable vehicle for a restrained new outreach.

Attention has already been devoted to the proposition that courts should be free to control market-distorting behavior indulged in by firms with otherwise legitimate monopoly power. ${ }^{139}$ This behavior could be described as monopolization or as an attempt. Either characterization would easily dispose of situations in which the monopolist is threatening competition in a market in which it is directly engaged. ${ }^{140}$ The monopolization characterization, however, can be applied much more readily to situations in which the monopolist is not engaged in the threatened market. ${ }^{141}$

Monopolization doctrine could also be used to control the behavior, or even the structure, of oligopolistic industries. It has been urged rather frequently that each member of an oligopoly has monopoly power by virtue of its share in an industry so structured that competition can be avoided.142 If it is further determined that oli-

137. See.Part IV(B)(2) infra.

138. See Parts V-VI infra.

139. Part $\mathrm{I}(\mathrm{C})(3)(c)$ supra.

140. See text accompanying notes 109-11 supra.

141. See text accompanying notes 109-11 supra; text accompanying notes $178-79$ infra. 142. See, e.g., authorities cited in notes $125-27$ stupra. 
gopoly structures should nonetheless be allowed to continue, it is still possible to use monopolization doctrine to control individual firm behavior, since in any concentrated oligopoly, the leading firms collectively hold monopoly power. ${ }^{143}$ For example, in the hypothetical example given at the beginning of this Article, ${ }^{144}$ documentary evidence showed conclusively that a firm with five per cent of the relevant market engaged in predatory pricing in order to eliminate a firm with fifteen per cent, resulting in an industry structure in which the firm with five per cent gained a ten per cent share, while the remaining two firms enjoyed thirty per cent and sixty per cent shares. Even if the oligopoly structure is allowed to persist, it would be easy to conclude that the shared monopoly power of the firm with the ten per cent share is distinctively outlawed by the tactics used in enlarging its share. Whether or not an effort might be made to dissolve the firm on that basis, a treble damage remedy for the victim could easily be provided.

Similar analysis could be employed in the related introductory example. ${ }^{145}$ The twenty-eight and twenty-five per cent market shares held by Goodyear and Firestone in the replacement tire market might be dissolved or otherwise controlled if there is adequate basis for concluding that the tactics of acquiring those market shares lack any redeeming efficiency virtue.

The introductory example of fraudulent patent procurement provides a useful further test of the possibilities of monopolization doctrine. The Supreme Court has ruled that efforts to enforce a patent procured by fraud on the Patent Office may violate section 2 as monopolization or an attempt to monopolize. ${ }^{146}$ The opinion seems to state that for either offense it would be necessary to appraise the exclusionary power of the illegal patent claim in terms of the relevant market for the product involved.147 The opinion, however, affords scant support for concluding that the Court has deliberately chosen to continue the relevant-market requirement for attempts, in large part because the Court suggested that it might be prepared to rule, on a fully litigated record, that such conduct amounts to a per se violation of section 2.148 At least to all appearances, this conclusion

143. See text accompanying notes $126-27$ supra.

144. See text accompanying notes 2-3 supra.

145. See text accompanying notes 4-6 supra.

146. Walker Process Equip., Inc. v. Food Mach. \& Chem. Corp., 382 U.S. 172 (1965).

147. 382 U.S. at 177-78. The conclusion that a relevant market is needed in such cases has been applied by many subsequent decisions. E.g., Acme Precision Prods., Inc. v. American Alloys Corp., 484 F.2d 1237 (8th Cir. 1973); SCM Corp. v. RCA, 318 F. Supp. 433, 472-73 (S.D.N.Y. 1970).

148. 382 U.S. at 178. In addition, it is clear from the opinion that attention was in no 
of per se illegality would entirely dispense with any market inquiry, even for a monopolization offense. And the case for finding a per se violation in cases of fraudulent patent procurement is indeed strong.

The basic arguments against finding a per se violation revolve around the proposition that even a fraudulently procured patent may have no significant exclusionary impact. Far too many patents are held invalid for reasons that are quite independent of any fraud on the Patent Office and that are knowable to anyone threatened with infringement claims or offered the protection of a license. ${ }^{140}$ Even apart from invalidity, interpretation of the arcane language of patent claims may limit the patent's apparent coverage to matters of trivial inconsequence, particularly with the aid of such abstruse patent law doctrines as "file wrapper estoppel." 160 Finally, even a valid patent often covers only matters of little or no commercial significance.

Notwithstanding these considerations, the case for imposing liability on a firm that tries to enforce a patent known to have been fraudulently procured verges on the overwhelming. It is extraordinarily hard to conjure up the competitive advantages of deliberate fraud. The effort to enforce the patent in itself reflects the judgment of the firm that some commercial gain can be reaped from the effort. The impact of the patent on rivals in the marketplace may easily reach far beyond the limits that a court would ultimately place on it; ignorance, uncertainty as to eventual judicial interpretation, the great cost of patent litigation, the ease of accepting license arrangements that have been accepted by most competing firms, and the disastrously broad effects frequently produced by threats against customers of the coerced firm all contribute to this result. Although the brocard that a patent is a legally conferred monopoly ordinarily carries precious little value, certainly an attempt to enforce a fraudulently obtained patent would justify taking the bad actor at the full

way focused on the question whether the relevant market must be shown for an attempt offense. Thus, the Court's statement is, at most, simply the reflection of an easy assump. tion.

149. It has been stated that 72 per cent of the patents that have been litigated in the courts of appeals since 1966 have been held invalid. Speech by Bruce B. Wilson, Deputy Assistant Attorney General, Antitrust Division, to Philadelphia Patent Low Association, Nov. 30, 1972, in BNA ANrrtrust \& TrADE REg. REP., Dec. 5, 1972, at D-1, $\mathrm{D}-2.1966$ is the year of the Supreme Court's most important recent pronouncement on standards of patentability. See Graham v. John Deere Co., 383 U.S. I (1966).

150. See, e.g., Graham v. John Deere Co., 383 U.S. 1 (1966); Exhibit Supply Co. v. Ace Patents Corp., 315 U.S. 126 (1942); Ziegler v. Phillips Petroleum Co., 483 F.2d 858, 870-71, 877 (5th Cir. 1973); Williams Bit \& Tool Co. v. Christensen Diamond Prods. Co., 399 F.2d 628 (5th Cir. 1968); Eastern Rotorcraft Corp. v. United States, 397 F.2d 978 (Ct. Cl. 1968); Thabet Mfg. Co. v. Kool Vent Metal Awning Corp. of America, 226 F.2d 207 (6th Cir. 1955). 
value of its own judgment and imposing monopolization liability for misuse of rights falling into an otherwise valid category of "monopoly."

Other examples of the need to expand single-firm control may be found. The other two introductory examples, ${ }^{151}$ which involve general practices of reciprocity and competition by a manufacturer with its independent distributors, might conceivably be among them. ${ }^{152}$ Insistence that any conclusion of illegality be couched in terms of monopolization rather than attempt may have the advantage of ensuring that careful thought is devoted to the questions before answers are given.

Expanding the reach of section 2 through the concept of monopolization has an incidental intellectual advantage in addition to the pragmatic advantage of deterring over-eager action. Although it is difficult to understand the role of attempts as a judicially defined offense cognate to the judicially defined monopolization offense, ${ }^{153}$ it is more than difficult to understand the character of an "attempt" offense that is not proximate to a completed offense. If monopolization doctrine is used to reach those varieties of single-firm behavior that should be judicially controlled, attempt doctrine can be expanded in the traditional dependent fashion, if only to obey the statutory mandate that there be an attempt offense. Courts may continue to reserve an arbitrarily selected bottom range of offensive conduct to be called attempt rather than monopolization. Dangerous probability and conduct approaching monopolizing conduct would remain the watchwords.

Despite these advantages of expanding the monopolization offense, some minor advantages may be found in expanding the attempt offense. As previously noted, ${ }^{154}$ fewer doctrinal obstacles would be encountered. In addition, some cases now brought as monopolization cases could be simplified. If conduct sufficient to meet the attempt requirements could be shown, and if measurement of market power were relegated to a lesser role in assessing conduct, it might be possible to avoid the prolonged trials of relevant market issues now characteristic of monopolization cases. Suits would instead be brought for the attempt, and the question of monopoly would be disregarded entirely. ${ }^{155}$

151. See text between notes 8 \& 11 supra.

152. See text accompanying notes 259,296 infra.

153. See Part I(D) supra.

154. See text accompanying notes $137-38$ supra.

155. There might be some concern that different relief should be given for monopoli- 
The relative ease with which the courts might be persuaded to expand attempts, in short, continues to exert a strong attraction. Attention may thus be turned to the recent opinions that have accepted the invitation to expansion, and then to the older authority that supports such action.

\section{Contemporary Expansions of the Attempt Offense}

The critical purpose behind expanding the attempt offense is to reach single-firm behavior that would otherwise lie beyond the reach of the antitrust laws. A significant number of recent decisions have undertaken such expansion by focusing primarily on the unreasonable intent or behavior of the accused firm and subordinating the ordinarily required element of dangerous probability of monopolization. Some of these decisions dispense with the dangerous probability requirement by simply ignoring it; ${ }^{\mathbf{1 5 6}}$ others deal with the requirement ambiguously; and still others face the problem explicitly, either rejecting or at least discrediting the requirement. Most of these opinions share an important attribute: Liability either is not imposed at all or is rested alternatively on strongly supported traditional grounds.

The least adventurous approach in the decisions that expand the attempt offense is found in the statement that the dangerous probability requirement does not demand an assessment of the actual likelihood of success in attaining market power but, instead, requires a combined evaluation of the actor's ability to achieve the forbidden result, of its intent, and of its overt acts. ${ }^{157} \mathrm{~A}$ bolder approach suggests that specific intent to monopolize is enough if the intent is inferred from conduct that itself is a sufficiently substantial restraint of trade to create the dangerous probability. ${ }^{158}$ Another court, with-

zation than for a mere attempt. For example, the possibility that cellophane might be found a part of trade or commerce with respect to an attempt charge, even though the relevant market for the monopolization charge in Cellophane was found to include all flexible packaging materials, led one writer to ask what sort of relief should be available where only the attempt was found when in fact there was monopoly. Marcus, supra note 126, at 185, 192 n.27. The answer, of course, is that the availability of any form of relief is not to be determined by the legal label applied to the violation found. See Turner, supra note 25 , at 318 . The only danger is that the restricted attempt label may blind a court to the need for sweeping relief.

156. Support for this approach in earlier Supreme Court decisions is explored in Part IV(B) infra.

157. Kearney \& Trecker Corp. v. Giddings \& Lewis, Inc., 452 F.2d 579, 598 (7th Cir. 1971), cert. denied, 405 U.S. 1066 (1972).

158. See Dobbins v. Kawasaki Motors Corp., 362 F. Supp. 54 (D. Ore. 1973). Some support for this approach can be found in language appearing in Bushie v. Stenocord Corp., 460 F.2d 116, 121 (9th Cir. 1972). The court made it explicit in Dobbins that a 
out expressly rejecting the dangerous probability requirement, has stated that a violation must rest either on showings of achieved substantial market power or on acts of a clearly anticompetitive nature from which a specific intent to monopolize can be inferred. ${ }^{159}$

More adventurous opinions have expressly rejected any semblance of the dangerous probability requirement. The foremost decision is Lessig v. Tidewater Oil Co., ${ }^{160}$ an action brought by a former service station operator against his supplier. Ordering a new trial because of erroneous jury instructions, the court found sufficient evidence to support findings that Tidewater had violated section 1 of the Sherman Act and section 3 of the Glayton $\mathrm{Act}^{101}$ by fixing retail gasolineprices, enforcing obligations that dealers purchase their full requirements of petroleum products, and tires, batteries, and accessories, from the supplier, and tying an obligation to purchase the tires, batteries, and accessories to the lease of the station and the sale of petroleum products. The court further ruled that the same conduct should be submitted to the jury with instructions on attempts to monopolize. The opinion explicitly rejected any requirement that the plaintiff show a dangerous probability of attaining monopoly power in a relevant market. ${ }^{162}$ Instead, relying on the reference to intent and the "consequent" dangerous probability of success in the Swift opinion, ${ }^{183}$ the court concluded that specific intent is the only evidence of dangerous probability required by the statute. ${ }^{184}$ Probability of success was found to be simply one indication of intent. Statutory warrant for the result was found in the prohibition against attempting to monopolize "any part" of trade or commerce, which was equated with "an appreciable segment of interstate sales."165

Reliance on attempt doctrine seems entirely unnecessary to the disposition of a case such as Lessig, whether disposition be in favor of the claimant or the defendant. The activity involved inherently

violation of section 1, standing alone, might not be sufficient to constitute a still required dangerous probability of success.

159. See Huron Valley Publishing Co. v. Booth Newspapers, Inc., 336 F. Supp. 659, 662 (E.D. Mich. 1972).

160. 327 F.2d 459 (9th Cir.), reh. denied per curiam, 327 F.2d 478 (9th Cir.), cert. denied, 377 U.S. 993 (1964).

161. 15 U.S.C. $\S 14$ (1970).

162. 327 F.2d at 474 .

163. 327 F.2d at 474, citing 196 U.S. 375, 396 (1905). Only tangential footnote reliance was placed on the far stronger support found in other early Supreme Court decisions that will be examined in Part IV(B) infra. 327 F.2d at 474 n.26.

164. 327 F.2d at $474-75$.

165. 327 F.2d at $474-75$. 
includes the element of agreement or condition required to satisfy section 1 of the Sherman Act and section 3 of the Clayton Act. ${ }^{100}$ If those provisions have not been violated, it is difficult to determine why the conduct should be outlawed on some theory of single-firm behavior; if those provisions have been violated, no purpose is served by finding additional violations. Yet it may be that the court meant to limit its opinion to situations involving violation of the other statutes, for, in denying a petition for rehearing that had earnestly pressed the contention that the opinion had the effect of outlawing all competition, the court warned that its discussion of attempts must be read "in light of the anticompetitive purposes and conduct to which the case relates." 187

Whatever the court may have meant in denying the petition for rehearing, the Lessig opinion has had a remarkably checkered career even in the Ninth Circuit. It is surrounded by attempt decisions, shortly before and shortly after, in which the relevant market inquiry is made without any reference to the treatment of the issue in Lessig. ${ }^{168}$ Other opinions have undertaken to explain the Lessig doctrines, either defensively or critically. ${ }^{160}$ At least one opinion was initially published with an open question of the validity of Lessig; the reference mysteriously disappeared by the time of permanent publication in the Federal Reporter..$^{170}$

166. Section 3 embraces sales on an unlawful "condition," as well as "agreement, or understanding."

167. 327 F.2d at 478.

168, See Case-Swayne Co. v. Sunkist Growers, Inc., 369 F.2d 449, 454-59 (9th Cir. 1966), revd. on other grounds, 389 U.S. 384 (1967); Jerrold Electronics Corp. v. Wescoast Broadcasting Co., 341 F.2d 653, 664 (9th Cir.), cert. denied, 382 U.S. 817 (1965); Walker Distrib. Co. v. Lucky Lager Brewing Co., 323 F,2d 1, 9 (9th Cir. 1963); Independent Iron Works, Inc. v. United States Steel Corp., 322 F.2d 656, 668 (9th Cir.), cert. denied, 375 U.S. 922 (1963).

169. In Moore v. Jas. H. Matthews \& Co., 473 F.2d 328, 332 (9th Cir. 1972), the court relied upon Lessig for the propositions that proof of the relevant market is not required, that proof that there is a dangerous probability of success is enough, and that proof of relevant market may be relevant to the claim (the relevance of the relevant market is apparently drawn from the explicit recognition in Lessig, 327 F.2d at 474, that present power is relevant to the question of intent). In Industrial Building Materials, Inc. v. Interchemical Corp., 437 F.2d 1336, 1344 (9th Cir. 1970), the court stated explicitly that proof of the relevant market is not in issue in an attempt to monopolize case and then, without cross-reference, continued on to rule that if the plaintiff can show an intent to monopolize the entire industry, it may still prevail on a theory of attempt. See also Bushie v. Stenocord Corp., 460 F.2d 116, 121 (9th Cir. 1972) (defensive). The most recent pronouncement is Hallmark Indus. v. Reynolds Metals Co., 489 F.2d 8, 12 (9th Cir. 1973), where the court accepted the proposition that all that is required is "specific intent to set prices or exclude competition in a portion of the market without legitimate business purposes. This specific intent must be accompanied by predatory conduct directed to accomplishing the unlawful purpose."

170. Cornwell Quality Tools Co. v. C.T.S. Co., 446 F.2d 825 (9th Cir. 1971), cert. denied, 404 U.S. 1049 (1972). Fortunately, 1971 Trade Cas. If 73,620, at 90,563 n.1, 
The other most significant rejections of the dangerous probability requirement have occurred in a pair of cases brought by unsuccessful automobile dealers against their manufacturer-suppliers. Each case rested primarily on claims that competitive retailers subsidized by the manufacturers engaged in predatory competition. ${ }^{171}$ In each, the court withdrew claims of monopolization from the jury's consideration; in one, for example, it found that competition from other makes of cars would preclude a finding of monopolization even if Chrysler became the sole Dodge dealer in Allegheny County, Pennsylvania. ${ }^{172}$ Attempt claims were nonetheless submitted to the jury on the ground that specific intent to monopolize is itself enough, even without a possibility, let alone a dangerous probability, of monopolization. The more remarkable opinion is the earlier one, which is admiringly followed in the second. The apparent core of the reasoning is an analogy to an automobile race: Only one driver will win the Memorial Day 500, but all specifically intend to win it. ${ }^{173}$ No heed is paid to the fact that, on the court's own decision, the intent to "win" by becoming the sole Dodge dealer in Allegheny County is as innocent as the intent to win the race; completion of the intended conduct is no wrong. Some subsequent opinions have rejected the result on precisely this ground; ${ }^{174}$ the fact that the analogy fails and that the chosen explanation of decision is inadequate, however, does not of itself provide a satisfactory answer to the challenge that some more direct route may justify reaching the same result. ${ }^{175}$

preserves the statement that "[w]hile the principle of Lessig . . . remains the law of this circuit, its continuing vitality has been questioned." Although this note has been deleted from the opinion in 446 F.2d, the court does state that to prove an offense the plaintiff must prove a specific intent to monopolize and that the defendant "had sufficient market power to come dangerously close to success." $446 \mathrm{~F} .2 \mathrm{~d}$ at 832.

Cases outside the Ninth Circuit rejecting the Lessig opinion are catalogued in note 37 supra.

171. Rea v. Ford Motor Co., 355 F. Supp. 842 (W.D. Pa. 1972); Rea v. Ford Motor Co., 1972 Trade Cas. I 74,015 (W.D. Pa. 1972) (excerpts from jury instructions); Mt. Lebanon Motors, Inc. v. Chrysler Corp., 283 F. Supp. 453 (W.D. Pa. 1968), affd. on other grounds, 417 F.2d 622 (3d Cir. 1969).

172. 283 F. Supp. at $460-61$.

173. 283 F. Supp. at $461-62$.

174. None of the opinions discusses the text cases by name. The most explicit re: jection is found in Bowen v. New York News, Inc., 1973-1 Trade Cas. I 74,590, at. 94,605 n.5 (S.D.N.Y. 1973), where the court treats such a situation as one of "legal ... impossibility." See Madsen v. Chrysler Corp., 261 F. Supp. 488, 506-07 (N.D. Ill. 1966), vacated as moot, 375 F.2d 773 (7th Cir. 1967); United States v. Chas. Pfizer \& Co., 245 F. Supp. 737, 739 (E.D.N.Y. 1965): "Since the monopolization of citric acid does not offend $\S 2$ [because it is not the relevant market] . . . an attempted monopolization is equally inoffensive ....."

175. Ultimate disposition of the Mt. Lebanon case rested on a jury verdict finding 
A few other opinions have squarely dispensed with the dangerous probability requirement, without particularly advancing the course of analysis. ${ }^{176}$ The requirement is implicitly rejected in the small minority of opinions that have asserted that attempt violations may be found with respect to the products of a single manufacturer without regard to competing products. ${ }^{177}$ Finally, occasional suggestions are made that a firm may be found guilty of attempting to monopolize a market in which it is not engaged. ${ }^{178}$ Such a violation might rest on finding a dangerous probability that the incumbent being assisted will gain monopoly power, or might, instead, rest on dispensing with the requirement-the opinions are hardly enlightening. . $^{179}$

a violation and no damages. See Mt. Lebanon Motors, Inc. v. Chrysler Corp., 417 F.2d 622 (3d Cir. 1969). The trial court in Rea emphasized repeatedly that it believed that the judgment entered for the plaintiff on the jury's verdict could be completely supported under section 1 claims; thus, its extended discussion of attempted monopolization was simply added support for the result.

176. The most explicit opinion is Bowl America Inc. v. Fair Lanes, Inc., 299 F. Supp. 1080, 1093 (D. Md. 1969). Since the defendant had advanced itself from a market position of 33 per cent to one of 67 per cent by virtue of the challenged conduct, as measured by the most important of the relevant markets, the elimination of the dangerous probability requirement probably was not significant to the result. In addition, see Sam S. Goldstein Indus., Inc. v. Botany Indus., Inc., 301 F. Supp. 728, 736 (S.D.N.Y. 1969); McCormack v. Theo. Hamm Brewing Co., 284 F. Supp. 158, 165 (D. Minn. 1968).

An impossibly confused opinion is provided in Union Carbide \& Carbon Corp. v. Nisley, 300 F.2d 561 (10th Cir. 1961), cert. dismissed, 371 U.S. 801 (1962). Defendants, who had lost a jury verdict, complained on appeal about the lack of any statement of the need for dangerous probability in the jury instructions. The court found that there was no reversible error, although the requested instructions "may have been literally correct statements," because the jury was correctly instructed that there must be a specific intent to acquire market power and exclude others from competition. It is difficult to unravel the confusion implicit in the suggestion that it may be literally correct to require instruction on dangerous probability but is not reversibly erroneous to instruct only on specific intent. The court also approved a failure to instruct the jury on the relevant market, however, so in the end it seems safest to read the opinion as an unexplained determination that specific intent to monopolize alone will suffice. See 300 F.2d at 584-86.

177. E.g., Interphoto Corp. v. Minolta Corp., 295 F. Supp. 711, 715 n.1 (S.D.N.Y.), affd. on other grounds, $417 \mathrm{~F} .2 \mathrm{~d} 621$ (2d Cir. 1969); Rawlins v. American Oil Co., Civ. No. 89-67 (D. Utah, Oct. 1, 1969), appeal dismissed, (10th Cir. 1970) (instruction to jury quoted in ABA. ANTrTRUST SECTION, supra note 34, at 81-82).

178. See Interborough News Co. v. Curtis Publishing Co., 127 F. Supp. 286, 298 (S.D.N.Y. 1954), affd., 225 F.2d 289 (2d Cir. 1955) (exclusion of a single firm from a market in which defendants were not engaged not an attempt); Cape Cod Food Prods., Inc. v. National Cranberry Assn., 119 F. Supp. 900, 909 (D. Mass. 1954) (jury instructions); United States v. Paramount Pictures, Inc., 66 F. Supp. 329, 340 (S.D.N.Y. 1946), affd., 394 U.S. 131 (1948).

179. Mackey v. Sears, Roebuck \& Co., 237 F.2d 869 (7th Cir. 1956), appeal dismissed per stipulation, 355 U.S. 865 (1957), may' shed some light. The plaintiff alleged that Sears, Roebuck had deliberately attempted to drive him out of the manufacture of nursery lamps-and various other products he thereafter attempted to make-in retaliation for his refusal to lower the price at which he supplied Sears. The court ruled that no attempt to monopolize could be shown without proof of a dangerous probability that 
Conspiracy cases under section 2 offer a final strand to the pattern of current expansionary decision. Although few cases focus on the issue, it seems to be accepted that proof of relevant market or market power is not required in a conspiracy to monopolize case. ${ }^{180}$ The contrast with the majority view requiring such proof in attempt cases is underscored by a recent decision that expressly ruled that failure to prove a dangerous probability of monopoly precluded finding an unlawful attempt to monopolize but did not interfere with finding an unlawful conspiracy to monopolize. ${ }^{181}$

The superficially expansionary character of the conspiracy decisions is deceiving. As in the case of attempts, it may be earnestly argued that the lack of benefit from conspiratorial conduct justifies its prohibition regardless of the distance separating the conspirators from monopoly power. The argument makes sense; it makes so much sense that it has been adopted in a wide array of decisions finding. violations of section $1 .^{182}$ The result is that all possibility of independent substance has been drained from the offense of conspiring to monopolize. It is impossible to imagine a conspiracy to monopolize that is not also a conspiracy in unreasonable restraint of trade in violation of section 1; although some element of contemplation of monopoly power presumably remains to elevate only the most distinguished violations of section 1 to the dignity of concomitant violation of section $2,{ }^{183}$ the result simply allows courts to impose double criminal penalties on substantially the same conduct. ${ }^{184}$ In addition, a few cases seem to recognize an almost bizarre doctrine of conspiracy to attempt

Sears would achieve a monopoly. It may well be that Sears was not engaged at all as a manufacturer in competition with the plaintiff and came into competition only with his customers. The court probably meant to focus on an attempt to monopolize the retail sale of nursery lamps, a market in which the plaintiff was not engaged. In any event, the reliance on dangerous probability concepts does not shed much light on the approach the court might have taken if Sears had clearly been attempting to aid someone who was engaged in a market not occupied by Sears at any level.

180. See United States v. Consolidated Laundries Corp., 291 F.2d 563, 573 (2d Gir. 1961); United States v. National City Lines, Inc., 186 F.2d 562, 566-68, 573 (7th Cir.), cert. denied, 341 U.S. 916 (1951). Cf. Reliable Volkswagen Sales \& Serv. Co. v. World-Wide Auto Corp., 182 F. Supp. 412, 420-21 (D.N.J. 1960); Part IV(A) infra.

181. Bowen v. New York News, Inc., 1973-1 Trade Cas. I 74,590 (S.D.N.Y. 1973).

182. No market power is required to show some varieties of section 1 violations, such as pricefixing. The comparison between the market power requirements of sections 1 and 2 of the Sherman Act as to pricefixing was cast in modern terms by one of the most famous of the Supreme Court's footnotes. See United States v. Socony-Vacuum Oil Co., 310 U.S. 150, 224 n.59 (1940). Some inquiry into market power is, of course, involved in many species of section I violations, including some of the so-called "per se" offenses. See, e.g., Fortner Enterprises, Inc. v. United States Steel Corp., 394 U.S. 495 (1969).

183. See United States v. General Motors Corp., 1974 Trade Cas. I 74,879 (E.D. Mich. 1974).

184. See American Tobacco Co. v. United States, 328 U.S. 781, $788-89$ (1946). 
to monopolize. ${ }^{185}$ It does not seem possible that such a doctrine could be used to create a meaningful new category of behavior; it seems far more likely that such references are simply a special breed of the not uncommon tendency to use the attempt phrase as a slightly sloppy, nontechnical description of the tendencies of unreasonable concerted activity. ${ }^{186}$

The greatest shortcoming of the contemporary attempt opinions that disregard the requirement of an approach to monopoly power is the lack of any coherent theory to explain the creation of a criminal attempt offense that is not closely related to the completed offense. Cases far older can be found to remedy that lack in highly persuasive, if not ultimately convincing, terms. Examination of the Supreme Court decisions, and of the legislative materials from which they draw, should serve to frame the argument.

\section{Classtc Expanstons of the Atrempt Offense}

\section{A. Statutory Language}

Section 2 prohibits monopolization or attempts or conspiracies to monopolize "any part of ... trade or commerce." As noted above, the Lessig opinion, in dispensing with any inquiry into market power in an attempt setting, treated this language as reaching any appreciable (and perhaps continuing) volume of sales. An effort to secure control over a regularly identifiable grouping of sales by improper means, in short, can be treated as an attempt to monopolize that "part" of trade or commerce.

Support for this reading can be found in several Supreme Court opinions. The strongest support can be found in United States v. Lehigh Valley Railroad Co., ${ }^{187}$ where the Court concluded, without anything approaching a relevant market investigation, that combination of corporations to control the supply of anthracite coal tributary to a single great railroad system is "an actual monopolization of a part of . . . trade or commerce in anthracite coal." Comparable support may be found in the decision on the pleadings in United

185. See United States v. American Oil Co., 249 F. Supp. 799, 808.09 (D.N.J. 1966); Basle Theatres, Inc. v. Warner Bros. Pictures Distrib. Corp., 168 F. Supp. 553, 561 (W.D. Pa. 1958); Cape Cod Food Prods., Inc. v. National Cranberry Assn., 119 F. Supp. 900, 909, 912 (D. Mass. 1954).

186. It has been noted that care must be taken to distinguish the use of the "attempt" phrase to describe or characterize the purpose of concerted activity. Smith, supra note 33, at 241. See, as typical illustrations, Morton Salt Co. v. G.S. Suppiger Co., 314 U.S. 488, 493 (1942); Fashion Originators' Guild of America v. FTC, 312 U.S. 457, 466.67 (1941).

187. 254 U.S. $255,269-70$ (1920). 
States v. Yellow Cab Co. ${ }^{188}$ There the Court ruled that, on appropriate showing of intent, the deliberate acquisition by a taxicab manufacturer of control of taxicab operating companies could be found to be an unlawful conspiracy to monopolize a part of trade or commerce regardless of the proportion of total national cab sales involved; the Court's reference to the broad purpose of the Sherman Act to sweep away all appreciable obstructions to commerce might be found to extend this language to monopolization and attempts as well as conspiracies. ${ }^{189}$ Various other opinions supply derivative or obscure support. ${ }^{190}$

Surely the language of the statute can be read to reach deliberate acquisition of control over any continuing aggregation of sales opportunities, regardless of the relationship between that set of oppor-

188. 332 U.S. 218 (1947).

189. 332 U.S. at 225-26. The clouds surrounding the nature of the showings that would complete the violation are examined in Kitch, The Yellow Cab Antitrust Case, 15 J. LAw \& ECON. 327 (1972).

190. Leading status, of whatever sort, belongs to United States v. E.I. du Pont de Nemours \& Co., 351 U.S. 377, 395 n.23 (1956). In approaching the problem of market definition, the Court there distinguished several earlier decisions either as "not concerned with the problem that is now before the Court" or "concerned only with the question of whether there had been an attempt to monopolize." Of these cases, several involved resort to claims of attempt to monopolize only as a superfluous addition to challenges properly addressed to the concerted behavior of two or more firms. United States v. Columbia Steel Co., 334 U.S. 495 (1948); Fashion Originators' Guild of America v. FTC, 312 U.S. 457 (1941) (decided under section 5 of the Federal Trade Commission Act, 15 U.S.C. \& 45 (1970)); United States v. Associated Press, 52 F. Supp. 362 (S.D.N.Y. 1943), affd., 326 U.S. 1 (1945). Others involved a selection or assumption of a market that seems likely to satisfy current notions of market definition. E.g., TimesPicayune Publishing Co. v. United States, 345 U.S. 594 (1953); Lorain Journal Co. v. United States, 342 U.S. 143 (1951); United States v. Paramount Pictures, 334 U.S. 131 (1948). The remaining cases, in common with those just cited, do not reflect any coherent thought or suggestion bearing on the possibility that market analysis might play a different role in monopolization cases than in cases of attempt or conspiracy to monopolize. See Indiana Farmer's Guide Publishing Co. v. Prairie Farmer Publishing Co., 298 U.S. 268 (1934); Story Parchment Co. v. Paterson Parchment Paper Co., 282 U.S. 555 (1931). Pregnantly obscure, or obscurely pregnant, references to control of a part of trade or commerce are found, however, in the Times-Picayune, Lorain Journal, Columbia Steel, and Paramount Pictures opinions. See also American Tobacco Co. v. United States, 328 U.S. 781, 809 (1946). The Indiana Farmer's Guide opinion has suffered the strange fate of being quoted in subsequent opinions as if it had authored its quotation from the glotiously obscure statement in Standard Oil Co. v. United States, 221 U.S. 1, 61 (1911), that "[t]he commerce referred to by the words 'any part' [in Section 2] . . . has both a geographical and distributive significance, that is it includes any portion of the United States and any one of the classes of things forming a part of interstate or foreign commerce."

Lower court opinions can also be found that, without clear explanation, assume that it may be an offense to attempt to monopolize a "part" of trade or commerce that rather clearly would not satisfy ordinary market definition concepts. See Trans World Airlines, Inc. v. Hughes, 449 F.2d 51, $63-69$ (2d Cir. 1971), revd. on other grounds sub nom. Hughes Tool Co. v. Trans World Airlines, Inc., 409 U.S. 363 (1973); Englander Motors, Inc. v. Ford Motor Co., 267 F.2d 11, 14 (6th Cir. 1959); United States v. Klearflax Linen Looms, Inc., 63 F. Supp. 32, 39-40 (D. Minn. 1945). 
tunities and an economist's notions of a "market." The difficulty arises in explaining why a "part" of commerce should apparently entail measurement of a relevant market in monopolization cases but not in attempt or conspiracy cases. The explanation must be that, even with respect to monopolization, any identifiable grouping of sales does constitute a "part" of trade. Lack of market measurement with respect to attempts and conspiracies may then be justified in either of two ways: by finding a persuasive reason to distinguish such offenses from monopolization or by limiting the role of relevant market analysis even with respect to monopolization.

As explored in Parts II and III above, it is commonly urged that attempts and conspiracies be treated differently from monopolization because they involve inherently undesirable conduct. On the other hand, since unlawful monopolization may be found on the basis of highly ambiguous and potentially desirable conduct, the relevant market inquiry is needed to ensure that intervention occurs only in cases of significant danger. Support for this approach can be found in two highly ambiguous and unsatisfactory Supreme Court opinions of middling age. The alternative approach, drawing from the diffculty of establishing a logical line between attempts and monopolization, would be to discard the relevant market inquiry from monopolization doctrine as well as from attempt doctrine whenever the court is satisfied that unredeemably bad conduct is involved. Support for this approach can be found in the famous opinions of antitrust's classic era.

\section{B. Expansion in the Supreme Court}

1. Middle-Aged Opinions

Two famous decisions of a quarter century ago lend considerable support to those who wish to establish attempt violations on the basis of wrongful intent and conduct without regard to any proximity to monopoly power. Each failed to consider the question explicitly, however, and each refused to impose attempt liability.

The first of the cases is United States v. Columbia Steel Co. ${ }^{101}$ United States Steel bought a rolled steel plant in Utah as surplus property after the end of World War II; as part of the transaction, the Attorney General had advised the War Assets Administration that no antitrust violation was involved. Thereafter, United States Steel acquired the assets of Consolidated Steel Corporation, a steel fabricating concern that was both a customer for rolled steel products

191. 334 U.S. $495,530-33$ (1948). 
and a competitor in the sale of fabricated products. The acquisition was challenged both as a violation of section 1 and as an attempt to monopolize the market in fabricated steel products. The Court devoted most of its opinion, which approved the acquisition, to the conclusion that there was no unreasonable restraint in violation of section 1. The opinion concluded, however, with an examination of the attempt charge on the express premise that "even though the restraint effected may be reasonable under $\S 1$, it may constitute an attempt to monopolize forbidden by $\S 2$ if a specific intent to monopolize may be shown." 192 Although no violation was found, the premise of decision lends startlingly strong support to expansion of the attempt offense: A wrongful intent alone may be the basis for outlawing activity that clearly involves contract, combination, and conspiracy, and that has nonetheless been found so innocuous in actual impact as not to violate section 1 .

In some ways, the opinion in Times-Picayune Publishing Co. v. United States ${ }^{193}$ seems to lend even stronger support to the forces of expansion. Section 1 and attempt to monopolize charges were both advanced. The section 1 charge was based on imposition of a "unit plan" that required that some types of advertising be placed in both the morning and the evening newspapers published by a single publisher. The attempt charges renewed the attack on the unit plan and encompassed other varieties of conduct as well. The Court ruled that the publisher had not violated section 1 because the government had not shown a demonstrably deleterious effect on competition and because legitimate business aims had predominantly motivated adoption of the program. Turning to the attempt charges, it announced that section 2 required "a specific intent to destroy competition or build monopoly"104 and rested judgment for the defendant solely on the ground of honorable intent already found. ${ }^{195} \mathrm{It}$ would be possible to explain reconsideration of the unit plan on the ground that the Court was carried away by the force of its analysis of the other conduct underlying the attempt charge. Nonetheless, the opinion renews the implication in Columbia Steel that an attempt violation may be found in activity that is exonerated under section I because of its essentially reasonable character. In addition, the suggestion that the prohibited intent is the intent to destroy competition or build monopoly seems rather direct support for the argu-

192. 334 U.S. at $531-32$.

193. 345 U.S. 594 (1953).

194. 345 U.S. at 626.

195. 345 U.S. at 619-27. 
ment that anticompetitive behavior alone should constitute an attempt to monopolize.

If either of these opinions had recognized the problems of relating attempt violations to monopolization violations and had dealt with them explicitly, the current course of lower court authority might have been changed avulsively. As the opinions stand, they are generally disregarded and remain outside the main channels of still-current attempt doctrine.

\section{The Classic Era}

The dangerous probability requirement of the Swift opinion ${ }^{100}$ can easily be freed from any reference to monopoly power simply by considering the opinion in its contemporary setting.

Justice White's masterful opinion ${ }^{107}$ in Standard Oil Co. $v$. United States ${ }^{198}$ provides the primary justification for divorcing the attempt to monopolize offense from any relationship to monopoly power. The opinion begins with the proposition that the Sherman Act uses the concepts of "monopoly" and "restraint of trade" in a nontechnical way, freed of their original restrictive common law meanings. To Justice White the words had come to embrace all manner of acts that might produce the evil results attributed to crown-granted monopolies or self-imposed restraints on competitive freedom: elevation of price, restriction of output, and deterioration of quality. Conduct was to be measured against a rule of reason, in light of the surrounding circumstances and the moving intent. The prohibitions in section 2 were meant simply to complement section 1, "to make the prohibitions of the act all the more complete and perfect by embracing all attempts to reach the end prohibited by the first section ... even although the acts by which such results are attempted to be brought about or are brought about be not embraced within the general enumeration [of "every contract, combination," etc.] of the first section." ${ }^{190}$ Standard Oil's offenses were found to include not only monopolization, but also "a continued attempt to monopolize." 200 Without quoting at more burdensome

196. Swift \& Co. v. United States, 196 U.S. 375 (1905).

197. An admiring view of the opinion is by no means universal. Some of the criticism has been nearly vicious. See, e.g., Foulke, The Federal Anti-Trust Act of 1890, 62 U. PA. L. REv. 24I, 267 (1914); Jackson \& Dumbauld, Monopolies and the Courts, 86 U. PA. L. REv. 231, 247 (1938). For more appreciative views, see, e.g., Bork, Legislative Intent and the Policy of the Sherman Act, 9 J. LAW \& EcoN. 7 (1966); Hornblower, "Anti-Trust" Legislation and Litigation, 11 CoLUM. L. Rev. 701 (1911).

198. 221 U.S. 1 (1911).

199. 221 U.S. at 61-62.

200. 221 U.S. at 77. 
length, it is clear that the opinion supports use of monopolization and attempt offenses to reach any unreasonably anticompetitive behavior by a single firm. ${ }^{201}$ Two weeks later, in deciding United States v. American Tobacco Co., ${ }^{202}$ the Court used similar language and addressed itself to the question whether the acts of the defendants were "of such an unusual and wrongful character" as to bring them within the statute.

This approach to section 2 did not spring full-blown from the brow of Justice White. Attempt claims were included as a matter of routine in most of the early cases, ${ }^{203}$ quite probably as a reflection of considerable uncertainty as to the meaning of the prohibition. The very earliest opinions frequently responded to such claims by defining the outlawed attempt to monopolize as "an attempt to secure or acquire an exclusive right ... by means which prevent or restrain others," 204 and by permitting the quest for business at the expense of others only by means that leave "competitors free to make successful endeavors of the same kind." 205 It would be easy indeed to draw from such statements the proposition that to employ any means of competition that in some sense unfairly impedes the opportunities of others is an attempt to monopolize.

Reconciliation of this approach with the dangerous probability language in Swift is readily possible. Shortly before writing the Swift opinion, Justice Holmes wrote a dissent in Northern Securities Co. $v$. United States ${ }^{208}$ that anticipated the core of the Standard Oil approach. Restraint of trade was found to be the exclusion of

201. This expansive view of the opinion is stated most broadly in Jones, supra note 88, at 219-20.

202. 221 U.S. 106, 181 (1911).

203. See, e.g., United States v. Southern Pac. Co., 259 U.S. 214 (1922); United States v. Lehigh Valley R.R., 254 U.S. 255 (1920); United States v. Reading Co., 253 U.S. 26 (1920); United States v. Union Pac. R.R., 226 U.S. 61 (1912); United States v. Joint Traffic Assn., 171 U.S. 505 (1898); Hopkins v. United States, 171 U.S. 578 (1898); Anderson v. United States, 171 U.S. 604 (1898); United States v. Trans-Missouri Freight Assn., 166 U.S. 290 (1897).

Uncertainty as to the meaning of the atternpt offense may also be reflected in the fact that examination of several of the antitrust treatises of the 1890's and the early twentieth century has not uncovered any coherent treatment of the subject at all.

204. In re Greene, 52 F. 104, 116 (S.D. Ohio 1892). Like views, in collateral cases growing out of the same indictment, are to be found. In re Terrell, 51 F. 213 (S.D.N.Y. 1892); In re Corning, 51 F. 205 (N.D. Ohio 1892).

205. Whitwell v. Continental Tobacco Co., 125 F. 454, 462-63 (8th Gir. 1903). See also United States v. Whiting, 212 F. 466,478 (D. Mass. 1914); United States v. American Naval Stores Co., 172 F. 455, 457-58 (S.D. Ga. 1909). Echoes of the old phrases are still occasionally heard. See instruction to jury quoted in ABA ANTrTRUsT SECTION, supra note 34 , at $82-83$.

206. 193 U.S. 197, 400-11 (1904). 
others; ${ }^{207}$ the prohibitions of section 2 were found to be related to the prohibitions of section 1 in establishing "that whatever is criminal when done by way of combination is equally criminal if done by a single man." 208 It is possible to combine his two opinions into the proposition that, to be unlawful, an attempt to monopolize must approach dangerously near to monopolization but that monopolization itself is a behavioral offense that does not require any particular measure of power in an economically defined market. Unfair acts excluding competitors might alone constitute the offense.

Although the old language is still quoted on occasion, ${ }^{200}$ it has not yet been resurrected to establish any such expanded offense. Examination of the legislative history and contemporary thought, however, provides further support for any faithful believers who might wish to bend their efforts to accomplish that end.

\section{Expansion in Legislative History}

The nature of the expansionary arguments drawn from legislative history is easily stated: Congress, in passing the Sherman Act, had no clear notion of the legal doctrine it wanted; not even Senator Sherman, whose bills stimulated the legislative process into action, nor the draftsmen ${ }^{210}$ of the statute actually adopted wished to do more than grant a charter to the federal courts to decide what needed to be done. Particularly in the area of single-firm behavior, "The Act is necessarily vague, because, in men's minds, the evil dreaded is vague, and like words . . . have been used to express it."211 If, in the phrase of the 1930's, the statute is to be interpreted as a declaration of the principles of free enterprise constitutional in its majesty and breadth, ${ }^{212}$ it may easily be read in light of modern needs to

207. 198 U.S. at $404,409$.

208. 193 U.S. at 404.

209. E.g., Klor's, Inc. v. Broadway-Hale Stores, Inc., 359 U.S. 207, 211 (1959); Lorain Journal Co. v. United States, 342 U.S. 143, 153-54 (1951). The notion that "a monopoly under $\S 2$ is a species of restraint of trade under $\$ 1$ " is attributed in United States $v$. Socony-Vacuum Oil Co., 310 U.S. 150, 224 n.59 (1940), to the Standard Oil passage.

210. Although there was some initial uncertainty, it now seems to be agreed that Senator Edmunds probably wrote most of the actual statute, including section 2. See W. LeTwin, LAw and Economic Policy in AMERICA 94 (1965); H. Thorelli, Federac ANTITRUST POLICY 210-14 (1955); Walker, Who Wrote the Sherman Law?, 73 CenT. L.J. 257 (1911).

211. Dana, "Monopoly" Under the National Antitrust Act, 7 HARv, L. REv. 338, 355 (1894). Cf. Rahl, supra note 131, at 747: "Private monopoly, as distinguished from sovereign grant, had no distinct legal history, and Section 2 legislated upon an undefined thing in a most uncertain manner."

212. E.g., Sugar Institute, Inc. v. United States, 297 U.S. 553, 600 (1936). 
authorize judicial control of untoward competitive behavior no matter how far removed from a monopoly level of market power.

The most frequently noted feature of the legislative debates is the repeated protests of the important movers that the statute was simply designed to embody the principles of the common law. ${ }^{213}$ The history is ordinarily continued with a demonstration that the principles of common law had not developed into the general doctrines supposed in the debates. ${ }^{214}$ It is not as common to note the explicit admissions that content would have to be given to the statute by the courts. Such admissions came not only in despairing protests against the generality of the statute ${ }^{215}$ but also in confessions by its sponsors. ${ }^{216}$ This willingness to throw the matter over to the courts is undoubtedly the most important single source of justification for the very free approach that courts have in fact taken in attempting to apply the statute.

In addition, some small help may be found in a narrower approach to the legislative materials. Section 2 bears no resemblance to

213. E.g., 21 CoNG. REc. 2456 (remarks of Senator Sherman), 3146 (Senator Hoar), 3152 (Senator Hoar) (1890).

214. E.g., H. Thorenri, supra note 210, at 228-29; Bork, supra note 197, at 37; Dewey, The Common-Law Background of Antitrust Policy, 41 VA. L. REv. 759 (1955); Letwin, The English Common Law Concerning Monopolies, 21 U. CHI. L. Rev. 355 (1954). Cf. H. Packer, The State of Research in Antitrust law 24-25 (1963); T. Spelling, A Treatise on Trusts AND Monopolies 223-24 (1893); Pope, The Legal Aspect of Monopoly, 20 HARV. L. REv. 167, 182 (1907).

Some of the commentators of the period, however, urged vigorously that the principles of the common law did extend to at least most of the subjects that have now come to be embraced by the Sherman Act. See Adler, Monopolizing at Common Law and Under Section Two of the Sherman Act, 31 HARv. L. REv. 246, 251 (1917); Boisot, The Legality of Trust Combinations, 30 (n.s.-39 o.s.) AM. L. REG. 751 (1891) (urging that any corporation with undue power should be subject to charter forfeiture). Cf. Allen, Criminal Conspiracies in Restraint of Trade at Common Law, 23 HARv. L. REv. 531, 543-44, 546-47 (1910) (urging that combinations to create monopoly might be reached).

Today, of course, some state courts announce that their common law embraces the principles that have been developed under the Sherman Act. E.g., Collins v. Main Line Board of Realtors, $452 \mathrm{~Pa} .342,304$ A.2d 493, cert. denied, 42 U.S.L.W. 3247 (U.S., Oct. 23, 1973). Even if this sort of statement may be taken at face value, as seems highly dubious, it is, of course, far from any reflection of what state law would have become even in such states without the impetus provided by federal legislation and decisions. In like fashion, it has been urged that there is sufficient support in common law to develop principles analogous to the Sherman Act for Australia. See Little, Monopolization in Trade-A Kind of Intimidation, 6 MELBOURNE U. L. Rev. 265 (1968).

215. See 21 Cong. REc. 4095 (remarks of Representative Wilson), 4099 (Representatives Cannon and Bland), 5953 (Representative Morse), 5957 (Representative Stewart) (1890). Representative Bland's comment might be echoed in moments of frustration by antitrust lawyers even today: "God knows, for no man in this House knows, what else the bill will cover."

216. 21 CoNg. REc. 2460 (remarks of Senator Sherman), 4089 (Representative Culberson) (1890). The Supreme Court has quoted an article in which Senator Edmunds stated that every member of the Judiciary Committee agreed " "that it was quite impracticable 
anything contained in the original Sherman-sponsored bill referred to the Judiciary Committee; ${ }^{217}$ nothing in the legislative debates following report of the committee bill ${ }^{218}$ that was finally enacted without change as the Sherman Act touches in any useful way on the attempt prohibition. During debate of the committee bill, however, a motion was made to limit section 2 to combinations and conspiracies to monopolize because the meaning of a direct monopoly offense was obscure. Senator Hoar, one of the moving forces behind the bill, responded with a definition of monopoly that included "the sole engrossing to a man's self by means which prevent other men from engaging in fair competition with him."210 Senator Edmunds, probably the draftsman of section $2,{ }^{220}$ furthered the response with a definition that included the exclusive right of trading in any place or the control of the whole of some trade. He then stated that the section had been drafted as it was because "if one person alone... did it, it was just as offensive and injurious to the public interest as if two had combined to do it."221 Although the references to sole control might be read to invoke a modern-day concept of high levels of market power, these passages may also be read to support the Standard Oil conclusion that section 2 is aimed primarily at supplementing section 1 by extending its prohibitions to any unfairly exclusionary activities undertaken by a single firm.

Traditional approaches to legislative history can also be used to

to include by specific description all the acts which should come within the meaning and purpose of the words "trade" and "commerce" or "trust," or the words "restraint" or "monopolize," by precise and all-inclusive definitions; and that these were truly matters for judicial consideration.' " Apex Hosiery Co. v. Leader, 310 U.S. 469, 489 n.10 (1940), quoting Edmunds, The Interstate Trust and Commerce Act of 1890, 194 N. AM. REv. 801,813 (1911). Senator Hoar is likewise quoted as having advised clients in 1891 that a proposed pricefixing scheme seemed to him lawful under the statute but that: "The opinion of courts, like the opinion of the rest of the community, may vary in different generations as to what is reasonable. But the question of reasonableness will be a ques. tion of law for the courts, to be determined upon all the facts and in light of the ex. periences, the business habits, and the public opinion of the present time." Washburn, The History of a Statute, 8 Boston U. L. REv. 95, 99-100 (1928).

Certainly it was commonly recognized from the outset that the statute was essentially a delegation of law-making responsibility to the courts. E.g., Kales, supra note 72, at 439-34; Raymond, The Federal Anti-Trust Act, 23 Hanv. L. Rev., 353, 354 (1910).

217. Senator Sherman's bill was introduced on December 4, 1889, as S. 1, 51st Cong., Ist Sess. (1889) [21 CoNG. REc. 96 (1889)]. It went through many amendments before bcing referred to the Committee on the Judiciary on March 27, 1890. See S. Doc. No, 147, 57th Cong., 2d Sess. 69, 71, 89, 217, 277 (1903).

218. The bill reported by the Committee on the Judiciary was substituted in its en. tirety as an amendment to S. 1., 21 CoNG. REc. 2901 (1890).

219. 21 CoNG. REC. 3152 (1890).

220. See note 210 supra.

221. 21 CoNG. REC. 3152 (1890). 
reach a much different view. Other bills introduced in the 50th and 5lst Congresses unambiguously reached unfair competitive activity of a single firm, divorced from any requirement resembling modern notions of monopoly power. ${ }^{222}$ Failure to incorporate such provisions in the Sherman Act may be given the usual implication. ${ }^{223}$

Of far greater importance, the apparently casual origin of the attempt prohibition may be urged as virtually forcing the conclusion that the prohibition should not be given any vitally independent significance. The committee was drafting a criminal statute. It was clear that an attempt to commit a federal crime would not be punished unless the same statute created an attempt offense. ${ }^{224}$ Contemporary doctrines of criminal law, as those of today, uniformly regarded attempts in the light seen by the Court in the Swift deci-

222. E.g., H.R. 8054, 50th Cong., Ist Sess. 47 (1888) (" $[A]$ ny person. . . who shall prevent competition in the manufacture and sale of any article of merchandise with intent to unduly enhance the price thereof ... shall be known and designated as a trust . ..."); S. 6,51st Cong., Ist Sess. 411 (1889) ("[A]ll acts done by any person with a view of preventing, or which tend to prevent, full and free competition ... or which shall have the effect of advancing the cost ... to the consumer, are hereby declared to be unlawful to the extent herein provided ...."). These-and virtually all of the other antecedent bills-are helpfully gathered in S. Doc. No. 147, 57th Cong., 2d Sess. (1903).

223. On the other hand, it may be argued that the simple language of section 2 was intended to incorporate the full sweep of these provisions. For that matter, it has been argued that if section 2 had not been adopted at all it would be easy to reach positions of undue power simply by treating a single corporation-the only form of single entity that has given pause in the expansion of "combination" and "conspiracy" concepts-as a combination in restraint of trade. See Cox, Competition and Section 2 of the Sherman Act, 27 ABA ANTITRUsr SEction 72, 74-75 (1965). Compare the argument that the same result could be reached as a matter of common law in Boisot, supra note 214.

224. Apparently the lack of a general attempt offense can be traced to the dogma that there are no federal common law crimes, coupled with the fact that there has never been a general federal statutory prohibition of criminal attempts. Illustrative cases include Keck v. United States, 172 U.S. 434 (1899); United States v. Berrigan, 482 F.2d 171 (3d Cir. 1973); United States v. Joe, 452 F.2d 653, 654 (10th Cir. 1971); United States v. Lucas, 6 F.2d 327 (W.D. Wash. 1925). The Act of June 1, 1872, ch. 255, \$ 9, 17 Stat. 198, authorized conviction of an attempt to commit the offense charged in the indictment, "Provided, That such attempt be itself a separate offence." This statute has been embodied in FED. R. GrIM. P. 31(c).

One of the earliest decisions that faced the question whether common law offenses against the United States might be recognized involved an attempt charge, but the discussion focused entirely on the lack of statutory creation of the substantive offense. See United States v. Worrall, 2 U.S. (2 Dall.) 384 (D. Pa. 1798). Cf. Beale, Criminal Attempts, 16 HARv. L. REv. 491, 491 n.l (1903): "In jurisdictions where 'the common law of crime has been abolished,' i.e. where nothing is an offense unless made so by statute, an attempt to commit a certain crime may not be criminal because of the failure of any statute to declare it so."

Currently proposed criminal law revision statutes include general attempt provisions. See S. 1, 93d Cong., 1st Sess. \& 1-2A4 (1973); S. 1400, 93d Cong., Ist Sess. § 1001 (1973); Green \& Pochoda, Comment on Criminal Attempt and Criminal Solicitation: Sections 1001 and 1003 (1968), in National CoMm. on Reform of FEDERAL Criminal. Laws, WORKING PAPERS 351, 352, 354 (1970). 
sion: They are creatures of the completed substantive offense, to be defined and measured by the proximity of their approach to it. ${ }^{225}$

\section{Expansion of Monopolization}

Taken as a whole, the legislative history and classic decisions support use of section 2 as a means of outlawing single-firm behavior without regard to monopoly power. But they do not support a uniquely distinctive use of the attempt provision to reach this result. If anything, they justify an interpretation of the monopolization offense that would reach such conduct. The attempt provision would then stand only as a means of reaching activity that almost, but not quite, satisfied the requirements of monopolization.

In short, the argument returns to the idea of a continuum between monopolization and attempts to monopolize. If substantial elements of market power are to be discarded, they can most appropriately be discarded from both-just as Standard Oil may be read to do. If unambiguously bad conduct is involved, it would be condemned as monopolization without regard to market power. If the conduct is ambiguous, market power might be used as one measure of its desirability; illegality should depend on finding the high levels of market power presently characterized as monopoly power only if the conduct is subject to strong claims of justification. A court faced with the task of determining what business conduct should be outlawed must ask and answer the same questions whichever label is to be used. Only an arbitrary dividing line can be adopted to give content to the attempt prohibition as covering some more or less narrow zone of offensive conduct at the bottom end of the spectrum found to be undesirable.

At last, the question can be fully posed. It would be possible, without violating any canons of judicial restraint or any clear Supreme Court authority, to discard limiting definitions of the attempt offense found in the large majority of current lower court opinions. At the same time, it would be conceptually cleaner to expand monopolization doctrine in parallel fashion. Whether courts should yield to the seductive arguments of the contemporary challengers and give birth to a new offense is all that remains to be examined.

225. Among the leading works prior to 1890 , see $1 \mathrm{~J}$. BisHop, Cruminal LAW $\S \S 723$. 72a (7th ed. 1882); I F. Wharton, A TrEatise on Criminal LAW $\S 177$ (8th ed. 1880). slightly later works include 1 W. Clark \& W. Marshald, The Law of Crimes 279, 283 (1900). 


\section{The Hazards of Regulating Competition by Judicial Process}

A desire to clean up the practices of the marketplace springs endemic in many breasts. Expanding section 2 into a pervasive remedy for undesirable single-firm competitive behavior would satisfy this desire. Grave dangers of mistaken judicial diagnosis, however, are inseparably involved with any such expansion. These dangers arise from the probability that judicial procedures, often resting on incomplete data adduced by opposing advocates and evaluated by adversary experts, may provide too little understanding of the efficiencies resulting from rivalrous behavior. The immediate consequence is that desirable conduct may be forbidden by judicial decree. A less immediate, but more pervasive, danger is that the uncertainties surrounding the process and criteria of judicial evaluation may deter much competitive activity that even courts would have found desirable.

\section{A. Misevaluating Competitive Behavior}

The dangers of mistakenly condemning desirable competitive behavior may be illustrated first by a brief review of the most commonly feared tactic, predatory pricing. The recent resurgence of attempt doctrine in refusal to deal cases may warrant the succeeding sketch of that area. A large range of other business tactics, illustrative of those challenged in cases brought on some form of monopolization theory, will then be listed simply to suggest the difficulties of discerning evaluation.

\section{Predatory Pricing}

Pricing below the levels set by rivals, the very heart of competition, has been unquestioningly accepted as a legitimate practice. ${ }^{228}$ Price cutting to the point of predation, however, has as readily been

226. E.g.,Schine Chain Theatres, Inc., v. United States, 334 U.S. 110, 120-21 (1948); Gold Fuel Serv., Inc. v. Esso Standard Oil Co., 306 F.2d 61, 64 (3d Cir. 1962), cert. denied, 371 U.S. 951 (1963); Allen Ready Mix Concrete Co. v. John A. Denie's Sons Co., 1972 Trade Cas. If 73,955 (W.D. Tenn. 1972); Centanni v. T. Smith \& Son, Inc., 216 F. Supp. 330, 340 (E.D. La.), affd. per curiam, 323 F.2d 363 (5th Cir. 1963). But see Telex Corp. v. International Business Machs. Corp., 1973-2 Trade Cas. If 74,774 (N.D. Okla. 1973), where the finding of unlawful monopolization seems to rest in large part on findings that IBM cut prices to levels below competitive prices. The findings that cost savings leading to some of the price reductions were smaller than the reductions do not involve any finding that prices were lower than IBM's costs. On the contrary, the court ex. pressly found that " $[t]$ here was no evidence that IBM reduced prices below cost and a reasonable profit." 1973-2 Trade Cas. at 95,409. 
condemned. Tradition has it that the robber barons of the nineteenth century expanded their monopolistic empires by such means. Supposedly they destroyed small, local competitors by selling below costs in competitive markets while recouping the expenses of the campaign from monopoly profits earned elsewhere. ${ }^{227}$ More recently, it has become fashionable to doubt the rationality of such tactics on theoretical grounds ${ }^{228}$ and to demonstrate by study of historical materials that the actual use of predatory pricing was at least very much less common than supposed.229 The tide of opinion has not swung completely, even among academics, ${ }^{230}$ and many less detached observers continue to share the passionate belief of small businessmen that they are regularly victimized by the predatory pricing policies of larger rivals. ${ }^{231}$ Such smoky clouds of belief may well be fed by factual fires. ${ }^{232}$ Even if predatory pricing does occur, however, the

227. See, e.g., Cassady \& Brown, Exclusionary Tactics in American Business Competition: An Historical Analysis, 8 UCLA L. REv. 88 (1961); Raymond, $A$ Statement of the Trust Problem, 16 FARv. L. Rev. 79, 91 (1902). This tradition may underlie a more contemporary suggestion that particularly severe limits should be placed on the competitive use of monopoly profits, even if they derive from an entirely lawful monopoly position. See Marcus, Monopoly Profits, Economic Impossibility, and Unfairness as AntiTrust Tests, 14 VAND. L. REv. 581 (1961).

228. E.g., Telser, Cutthroat Competition and the Long Purse, 9 J. LAw \&: Econ. 259 (1966). Some of the discussion is concerned with the question whether it is possible for a firm to engage in predation without itself being forced to bear the same or larger costs as it is imposing on its victims. See, e.g., G. StIGLER, THE ORGanization OF INDUSTRY 11318 (1968); Bork \& Bowman, The Crisis in Antitrust, 65 Colum. L. REv. 363, 367 (1965); Director \& Levi, Law and the Future: Trade Regulation, 51 Nw. U. L. REv. 281, 290 (1956). A meander along this path would carry discussion too far from present purposcs; suffice it to observe that there may be rational grounds to suppose that a predator may be able, in a real world that includes antitrust laws operating more efficiently against collusion and tighter forms of combination than against single-firm behavior, to engage in activity at lower costs than must be borne by a smaller rival seeking to respond.

229. The movement was started by McGee, Predatory Price Cutting: The Standard Oil (N.J.) Case, 1 J. LAw \& Econ. 137 (1958). See Elzinga, Predatory Pricing: The Case of the Gunpowder Trust, 13 J. LAw \& ECoN. 223 (1970).

230. See Yamey, Predatory Price Cutting: Notes and Comments, 15 J. LAw \& Econ. 129 (1972).

231. E.g., MacIntyre \& Volhard, Predatory Pricing Legislation-Is It Necessary?, 14 B.C. IND. \& Com. L. REv. 1 (1972). A Special Subcommittee on Small Business and the Robinson-Patman Act recently reported: "While Professor Stigler may find predatory pricing an unrealistic and nonexistent economic force, the subcommittee finds it an often-used means employed by particularly large sellers to gain dominant positions in local markets generally at the cost of viable small business enterprises actively engaged in attempting to compete vigorously in a free economy." H.R. REP. No. 1617, 91st Cong., 2d Sess. 40 (1970).

232. At obvious risk of dispute as to any one example, the following cases, among others, seem to involve either clear or highly probable uses of below-cost pricing tactics for purposes of disciplining or eliminating competition: Moore v. Mead's Fine Bread Co., 348 U.S. 115 (1954); Lloyd A. Fry Roofing Co. v. FTC, 371 F.2d 277 (7th Cir. 1966); Forster Mfg. Co. v. FTC, 335 F.2d 47 (1st Cir. 1964), cert. denied, 380 U.S. 906 (1965) (related private recovery on an attempt to monopolize theory is reported in Farmington Dowel Prods. Co. v. Forster Mfg. Co., 297 F. Supp. 924 (D. Me.), modified, 421 F.2d 61 
question remains whether it is possible to distinguish it from desirable pricing behavior. At a minimum, the diagnosis would require "a detailed and thorough understanding of the surrounding circumstances in all their complexity."233 Just how great this complexity may be deserves some reflection.

a. Legitimate "below cost" prices. Sales below a firm's average total cost are often not predatory but compelled by competition itself. Any sale that returns a margin above the added costs of making that sale is unimpeachably sound business practice if it is the best available opportunity. For instance, such sales may be forced by cyclic fluctuations in the economy as a whole, by the greater efficiency of rivals, by long- or short-run declines in industry demand, or by fluctuations in demand between differentiated varieties of a single product manufactured by different firms. Proof of the alternate opportunities open to the firm is, of course, highly difficult in itself. Moreover, proof of better opportunities may not mean that "below cost" pricing is predatory.

Sales made at prices below the best available price, and sales that do not return the added costs they entail, may be entirely legitimate. Justifiable reasons for such sales may include: temporarily low promotional prices to aid in entering a new market, in introducing a new product, or in expanding sales in an existing market; permanently low prices designed to expand sales to a point that will reduce costs below the initially losing price;234 temporarily or permanently low prices adopted to inform customers of the availability and qualities of a line of products, with low prices on the promotional goods recouped by higher prices on other goods in the same line; $;^{235}$ and prices designed as an investment to maintain marketing channels and a going organization in face of a market in which losses could be minimized by temporary closing.

(1st Cir. 1969)); E.B. Muller \& Co. v. FTC, 142 F.2d 511 (6th Cir. 1944); Porto Rico Am. Tobacco Co. v. American Tobacco Co., 30 F.2d 234 (2d Cir.), cert. denied, 279 U.S. 858 (1929); Bardahl Lubricants, Inc. v. Bardahl Oil Co., 1971 Trade Cas. I 73,467 (D. Mass. 1971) (at least if the showings made in support of preliminary injunctive relief can be accepted); Bergjans Farm Dairy Co. v. Sanitary Milk Producers, 241 F. Supp. 476 (E.D. Mo. 1965), affd., 368 F.2d 679 (8th Cir. 1966); United States v. Corn Prods. Ref. Co., 234 F. 964 (S.D.N.Y. 1916), appeal dismissed, 249 U.S. 621 (1919).

233. Yamey, supra note 230, at 135.

234. Something of this sort may very well have been involved in Continental Baking Co. v. Old Homestead Bread Co., 476 F.2d 97 (10th Cir. 1973), cert. denied, 42 U.S.L.W. 3246 (U.S., Oct. 23, 1973), where the defendant, Continental, opened a new bakery and operated at a loss until sales had expanded sufficiently to utilize at least 75 per cent of the new capacity. Judgment against Continental on a jury verdict was affirmed.

235. Telser, Abusive Trade Practices: An Economic Analysis, 30 LAW \& ConTEMP. Prob. 488, 495 (1965). 
Apart from such rational competitive motives, apparently predatory prices may result from ignorance rather than malice. Calculation of costs is less than precise; prices may be below costs simply because the firm does not know its own costs. On the demand side, a firm may mistakenly predict the responses of rivals to its own pricing moves and the resulting over-all impact on sales. More simply, the firm may misestimate the nature of the demand for its own products. Since price determines volume of output and volume affects unit costs, moreover, there is a germ of truth in the further observation that prices determine costs, as well as being determined by them. ${ }^{236}$

b. Inferences of predation. The circumstances that have been allowed to support an inference of predatory motivation are detailed largely in "primary line injury" cases arising under the Clayton Act, as amended by the Robinson-Patman Act. ${ }^{237}$ While it is tempting simply to refer to the nearly absurd result in the famous Utah Pie $e^{238}$ decision to illustrate the difficulties that have been encountered, ${ }^{230}$ it seems appropriate to list some of the factors that bear on the evaluation of pricing behavior. It should be no surprise that in the process of evaluation the inference of "predation" is largely reduced to a conclusional label expressing a value judgment that given pricing behavior was somehow inappropriate; the hypothetical illustration of self-confessed predatory motives set out in the Introduc$\operatorname{tion}^{240}$ is seldom matched by proof in the real world of litigation.

Drastic price cuts, themselves discriminatory, may, as noted by the Court in its Utah Pie opinion, ${ }^{241}$ offer grounds for question; any sudden departure from prior practice, particularly in an isolated situation, may call for explanation. If a showing of sales persistently below cost can be added, confidence in the diagnosis is increasedbut the difficulty of measuring costs in any but the grossest fashion suggests that the confidence is likely to be misplaced. ${ }^{242}$ Sales below

236. See F. Rowe, Price Discrimination Under the Robinson Patman Agt 31 (1962).

237. Clayton Act \& 2, 15 U.S.C. \& 13 (1970), formerly ch. 323, \& 2, 38 Stat. 730 (1914).

238. Utah Pie Co. v. Continental Baking Co., 386 U.S. 685 (1967).

239. A brief excoriation is Bowman, Restraint of Trade by the Supreme Court: The Utah Pie Case, 77 YALE L.J. 70 (1967). A more generalized reaction is Sherwood, Robinson-Patman Act Primary Line Injury: Meanderings from Porto Rico to Utah-and Be. yond, 16 UCLA L. REv. 304 (1969).

240. See text accompanying notes $2-3$ supra.

- 241. 386 U.S. at 702-03 n.14.

242. The difficulties of establishing costs to the satisfaction of judicial tribunals are well shown by experience with the "cost justification" defense to charges of price discrimination. See, e.g., H. TAgGaRT, Cost Justification (1959); Report of the Advisory 
the rival's costs may be some evidence that the firm is also selling below its own costs, but apart from that possibility it is difficult to be concerned that a more efficient firm may be hastening the demise of a less efficient firm.

A pattern of consistently undercutting others' prices may also offer some support. Examination of the entire pricing history of the market involved is necessary, however, to determine who initiated the pricing pattern. Unless the supposed predator is quite clearly responsible for initiating the price cuts, rather than responding to the moves of others or to general conditions, accusations of predation are apt to be misplaced. So, too, it seems necessary to examine patterns of price relationships between markets; unless prices in the contested market are persistently below prices in other markets, it is difficult to rely on temporary discriminations that are periodically erased or reversed.

New entrants into a market and firms with small shares in it are much less likely to be engaged in deliberate predation. Absolute size may likewise be relevant; a firm facing rivals of much larger absolute wealth is not likely to try to drive them out of the market. Measurement of entry barriers, if plausible, is of course vitally important; although a predator may hope to raise the barriers by demonstrating to potential competitors the costs of opposition, there is little likelihood that predatory tactics will be used to win a market whose easy entry conditions invite prompt destruction of any compensating monopoly profits. ${ }^{243}$

This bare catalogue of relevant considerations should be suffcient to demonstrate the fantastic difficulties of attempting to assess pricing behavior in any but the clearest cases. For the present, such

Committee on Cost Justification to the Federal Trade Commission (1956), in $1 \mathrm{~J} . \mathrm{RE}$ PRINTS FOR ANTITRUST L. \& ECON. 423 (1969).

These inherent difficulties may be exacerbated by almost deliberately perverse legal approaches. In evaluating a claim of predatory pricing, for instance, the Federal Trade Commission has recently ruled that it would not consider the actual costs of operating the over-all enterprise, where the owners had chosen to incorporate it into an operating company and a real estate ownership company; since the operating company was experiencing losses, the loss nature of the pricing was thought to be made out even though the enterprise as whole was making money. Fortunately, the pricing policy was found justified nonetheless. See United Fruit Co., [1970-1973 Transfer Binder] TRADE REg. REP. II 20,209 (FTC 1973).

243. Measured against these criteria, the $U t a h$ Pie claims of primary line violation, with or without regard to inferences of predatory intent, seem hopelessly unfounded. Much of the important factual detail is set out in the opinion remanding for a new trial after remand from the Supreme Court. Continental Baking Co. v. Utah Pie Co., 396 F.2d 161 (10th Cir.), cert. denied, 393 U.S. 860 (1968): 
difficulties are cheerfully faced or blissfully ignored in price discrimination cases. The availability of price discrimination doctrines, indeed, suggests that predatory pricing in itself can be remedied without expanding attempt or monopolization doctrine at all, since price predation is unlikely to be accomplished without either discrimination or a position that can be controlled under present monopolization doctrine. ${ }^{244}$ The lesson remains useful, however, against the day when price discrimination doctrine may be reconsidered: It would not be honest to argue for outright repeal of the price discrimination statutes on grounds of the availability of attempt doctrine, unless it is recognized that attempt doctrine may appropriately be confined to very narrow circumstances.

Of far greater importance, the lesson suggested by the paradigm of predatory pricing carries over to many other supposedly predatory tactics as well. Judicial assessment of business practices more esoteric than the simple fact of setting product prices is risky in the extreme.

Finally, it must be noted that the difficulties of diagnosing economic motives are not the only problems. So long as businesspersons act for noneconomic as well as economic purposes, there will be corresponding complications. For example, it was asserted in 1973 that major integrated refiners had not allowed retail prices to rise as high as they should in response to gasoline shortages, thereby creating a squeeze that made it difficult for independents to maintain their customary retail differentials below major brand prices. ${ }^{245}$ Little imagination is needed to conjure up the purely political motivations that might prompt the major firms to exert pressure on their own dealers (preferably short of vertical price-fixing violations) to avoid the appearance of profiteering from shortage. If they also find a certain pleasure in the difficulties of the independents, it would doubtless take a highly trained psychoanalyst to tell the major firms just what their collective motives really are.

\section{Refusals To Deal}

Efforts have frequently been made to find an antitrust violation in the refusal by a single business firm to deal with another. The failure to create any general obligation to deal has rested on many grounds. Judicial evaluation of a firm's determination of a customer's credit-worthiness, for instance, has obvious hazards. Even as to

244. Section 3 of the Robinson-Patman Act, 15 U.S.C. \& 13a (1970), is also available. 245. See Permanent Subcomm. on Investigation of the Senate Comm. on Govern. ment Operations, 93D Cong., 1st. Sess., Investigation of the Petroleum Industry 39 (Comm. Print 1973) (FTC Preliminary Staff Report). 
cash customers, refusals to deal may rest on sound business reasons. A supplier (and perhaps a family of franchisees as well) may be concerned with maintaining the image of its product; with being exposed to litigation, whether for product liability or as a result of the customer's general litigiousness; with rewarding customer loyalty, when rationing is necessary; or with avoiding generally disruptive relationships. There may be, as well, an abstract value simply in preserving the freedom of businessmen not to deal with those they do not like, subject to the tight limitations resulting from antidiscrimination legislation.

The general antitrust freedom to refuse to deal, however, is qualified by requiring "the absence of any purpose to create or maintain a monopoly."24e The immediate question is whether this qualification should be expanded, by means of monopolization or attempt to monopolize doctrine, into a much broader duty of dealing than has so far emerged.'

The easiest cases for recognizing a duty to deal involve a combination of competitors who jointly control a means of competition that is beyond independent duplication and that is essential or very important to competitive survival. ${ }^{24 \tau}$ In these circumstances, recognition of a general right of access to the joint facilities, even for those who have not shared the costs and risks of initial formation, ${ }^{248}$ need not break new ground. Decision could as easily be rested on section 1 as on section 2.

So, too, it is easy to accept decisions that a firm with an established monopoly position may not use its power to limit or exclude competition by refusing to deal with customers who deal with its rivals. ${ }^{249}$ Again, it would be possible to resort to combination or

246. United States v. Colgate \& Co., 250 U.S. 300, 307 (1919). The Court's further ruling that, "of course," a firm may announce in advance the circumstances in which it will refuse to deal has given way to a practical recognition that such an advance announcement is an effective means of bringing others into combination to pursue jointly a desired form of conduct. See generally Turner, supra note 125, at 684-705.

247. E.g., United States v. Terminal R.R. Assn., 224 U.S. 383 (1912); Gamco, Inc. v. Providence Fruit \& Produce Bldg., 194 F.2d 484 (1st Cir.), cert. denied, 344 U.S. 817 (1952); United States v. Southwestern Greyhound Lines, Inc., 1953 Trade Cas. If 67,470 (N.D. Okla. 1953).

Associated Press v. United States, 326 U.S. 1 (1945), usually cited for this proposition, actually affirmed a decree that made explicit provision for refusing access so long as there was no discrimination against competitors of present members as such.

248. The Department of Justice has regularly reaffirmed the existence of such a duty in broad terms. See, e.g., Speech of Donald I. Baker, Director of Policy Planning, Antitrust Division, in BNA ANTITRUST \& TrADE REG. REP., Oct. 31, 1972, at A-7.

249. See Lorain Journal Co. v. United States, 342 U.S. 143 (1951). The same principle extends to refusals to deal with customers who deal with rivals on unacceptable terms. See North Texas Producers Assn. v. Metzger Dairies, Inc., 348 F.2d 189 (5th Cir. 
conspiracy doctrine; in any event, such misuse of an established monopoly position can be reached without the resort to attempt doctrine occasionally found in such cases. ${ }^{250}$ Likewise, use of refusals to deal to distort competition in a second market may be reached either as monopolization by improper use of monopoly power already possessed or as combination in restraint of trade..$^{251}$

Much greater difficulty is presented by some vertical integration situations. Several courts have recognized what might be called the right to refuse to disintegrate: A firm that has its own established marketing channels is not generally compelled to sell its product to others who would like to distribute the product. ${ }^{252}$ Quite recently, however, the Supreme Court has ruled that an electric power system may not refuse to make its transmission facilities available, or refuse to sell power at wholesale to municipalities who wish to substitute for the system's prior local distribution their own local distribution of electricity. ${ }^{253}$ It is difficult to know whether the decision means that any monopolist must now deal with would-be distributors who wish to institute competitive sale of its products; the result may have been unconsciously influenced by traditional attitudes toward public utilities. ${ }^{254}$ Reliance was squarely placed on the great level of market power enjoyed by the established distribution system, but the Court rested its decision more explicitly on attempt doctrine than

1965), cert. denied, 382 U.S. 977 (1966); Kansas City Star Co. v. United States, 240 F.2d 643 (8th Cir.), cert. denied, 354 U.S. 923 (1957). Cf. Union Leader Corp. v. Newspapers of New England, Inc., 284 F.2d 582 (1st Cir. 1960), cert. denied, 365 U.S. 833 (1961), where a boycott was organized in somewhat different terms.

250. The leading illustration is Lorain Journal Co. v. United States, 342 U.S. 143 (1951), where reliance is placed on attempt doctrine rather than on a combination of attempt and monopolization doctrine, as ordinarily occurs.

251. See, e.g., TV Signal Co. v. American Tel. \& Tel. Co., 462 F.2d 1256 (8th Cir. 1972); Six Twenty-Nine Prods., Inc. v. Rollins Telecasting, Inc., 365 F.2d 478 (5th Cir. 1966); Packaged Programs, Inc. v. Westinghouse Broadcasting Co., 255 F.2d 708 (3d Cir. 1958). The great source of authority for such concepts is United States v. Griffith, 334 U.S. 100 (1948).

252. E.g., Best Advertising Corp. v. Illinois Bell Tel. Co., 339 F.2d 1009 (7th Gir. 1965) (it is not entirely clear whether the court meant to rule both on the merits and on the commerce reach of the Sherman Act); A-1 Business Mach. Co. v. Underwood Corp., 216 F. Supp. 36 (E.D. Pa. 1963); La Rouche v. United Shoe Mach. Corp., 166 F. Supp. 633 (D. Mass. 1958).

253. Otter Tail Power Co. v. United States, 410 U.S. 366 (1973). See text accompanying notes 104-06 supra.

254. Much of the opinion is devoted to the bearing of the Federal Power Act on the appropriate antitrust disposition. Cf. Denver Petroleum Corp. v. Shell Oil Co., 306 F. Supp. 289 (D. Colo. 1969).

Other cases have continued to rule that a firm controlling a facility uniquely advantageous for some particular business endeavor may limit or deny access to it. See, e.g., Export Liquor Sales, Inc. v. Ammex Warehouse Co., 426 F.2d 251 (6th Cir. 1970), cert. denied, 400 U.S. 1000 (1971). 
on monopolization. Decision, however, should rest on the duty of a monopolist to deal fairly ${ }^{255}$ and cannot derive any independent strength from notions of attempt.

In theory, it is difficult to understand why a firm should enjoy less freedom to terminate established independent dealers in favor of its own integrated distribution efforts than to refuse to deal with new distributors. Nonetheless, there is subsitantial authority suggesting at least that a firm that enjoys monopoly power in production cannot simply terminate its dealers. Termination is seen as a means of destroying competition with the monopolist's own distributional efforts. ${ }^{256}$ Such cases are singularly silent on the duration of the duty to continue dealing with the present distributors; nor do they discuss the extent to which courts might control the terms of dealing with distributors in order to prevent "unfair" competition by their supplier. ${ }^{257}$ The difficulties being invited hardly need comment.

255. See Parts I(C) (3)(C), I(D), II(D) \& IV(D) supra.

256. The progenitor is Eastman Kodak Co. v. Southern Photo Materials Co., 273 U.S. 359 (1927), affirming a finding of liability under section 2 that rested on a refusal to continue supplying a distributor who competed with the supplier and who had refused an offer to purchase his business. It is not at all clear whether the ruling rests on notions of attempt to monopolize the distribution business, monopolization of the supply business, or misuse of a monopoly of the supply business. Cf. United States v. Eastman Kodak Co., 226 F. 62, 75-77, 79-80 (W.D.N.Y. 1915), appeal dismissed, 255 U.S: 578 (1921), which may suggest that Kodak's dealings in distribution were found uniawful as part of the scheme to monopolize manufacture.

More recent cases include Pollèr v. Columbia Broadcasting Sys., Inc., 368 U.S. 464 (1962); United States v. Klearflax Linen Looms, Inc., 63 F. Supp. 32 (D. Minn. 1945) (effort to exclude established distributors from sales to a particular customer).

A very explicit rationale is advanced in Poster Exch., Inc. v. National Screen Serv. Corp., 431 F.2d 334, 339 n.13 (5th Cir. 1970), cert. denied, 401: U.S. 912 (1971): "It is enough ... that National Screen had monopoly power at the manufacturing level and used it to prevent competition at the distributor-jobber level." "Moreover," the court continued, 43I F.2d at 339, "the Supreme. Court has long ago [in Eastman Kodak] condemned a vertically integrated manufacturer-retailer from using its. power at one level to drive out competition at another."

257. Some hint of the difficulties may be reflected in the concluding paragraphs of an opinion that recently determined that, as a matter of common law, a "franchise" relationship between a dominant and a subservient marketing party cannot be terminated without good cause:

We are not called upon to decide whether the relationship is so personal it would not survive Marinello's disability or death. We also reserve the question of the - particular remedy to which Marinello would be entitled (injunctive relief or compensatory damages) should shell in good faith opt to operate the station [which it * owned] itself.

The lease and dealer agreement, of course, would be subject to revision to conform with current Shell dealer operational practices for the area. The good faith of the parties and the reasonableness of their respective positions in the negotiations would determine the existence of good cause should the negotiations fail and Shell give notice of termination.

Shell Oil Co. v. Marinello, 63 N.J. 402, 411, 307 A.2d 598, 603 (1973), cert. denied, 42 U.S.L.W. 3468 (U.S., Feb. 19, 1974). 
The problem of attempt analysis arises at this point. What should be done if the supplier does not have monopoly power in its own market? Should courts nonetheless decide to dispense with market analysis and proceed to employ criteria of fairness to determine whether refusals to deal, competition between supplier and distributors, or even the terms of dealing with distributors constitute an attempt to monopolize distribution of the firm's own product?

Efforts to extend attempt analysis to refusals to deal by nonmonopolist suppliers are at least suggested in recent decisions, ${ }^{268}$ but the limits of the decisions are unresolved. They might lead to the conclusion that any firm producing a differentiated product is required to retain its independent distributors unless it can demonstrate that efficiencies would be achieved by integrated, exclusive distribution. Even this conclusion threatens to interfere with desirable efficiencies, however, since they might not be easily susceptible of judicial proof. At the other extreme, such decisions might lead to the conclusion that a producer may not enter into competition with its current distributors, even if they are not terminated as distributors, for fear that the producer might so control the terms of its dealings with them as to curtail or eliminate their competition. The efficiency losses from any such rule would be obvious and severe.

In related fashion, courts may seek to regulate competitive behavior by an integrated supplier who is competing with independent distributors of its own product. The automobile dealer cases used as the fourth example in the Introduction ${ }^{269}$ could represent the start of a broad trend. The underlying concern is presumably a vague fear of "predation" combined with an instinctive belief that suppliers may be particularly prone and able to destroy the distributive competition of independent firms. Again, the dangers of judicial intervention are apparent. Integration by the supplier that bypasses market transactions with independent distributors may give rise to many efficiencies, but the difficulty of establishing the efficiencies to judicial satisfaction may lead to untoward intrusion in the name of fairness.

258. See Industrial Bldg. Materials, Inc. v. Interchemical Corp., 437 F.2d 1336, 1344 (9th Cir. 1970); Morton Bldgs. of Neb., Inc. v. Morton Bldgs., Inc., 333 F. Supp. 187 (D. Neb. 1971). Cf. N.W. Controls, Inc. v. Outboard Marine Corp., 333 F. Supp. 493, 517 (D. Del. 1971), where the court treats seriously, but rejects as a matter of fact, the assertion that the defendant refused to purchase from the plaintiff remote control cables for operating outboard motors of defendant's own manufacture, as part of an attempt to monopolize the market for cables designed to operate motors made by the defendant. Similar claims were involved, but not decided, in Deterjet Corp. v. United Aircraft Corp., 211 F. Supp. 348 (D. Del. 1962).

259. See text between notes 7 \& 8 supra. 
Regulation might even be expanded beyond supplier competition with distributors to reach the terms of dealing between the supplier and its distributors. So far, courts have generally resisted efforts to invoke attempted monopolization analysis in cases of exclusive dealing, ${ }^{260}$ of substitution of one exclusive dealer for another, ${ }^{261}$ of change in dealer classification to a less-favored discount status, ${ }^{262}$ or of simple termination because of dissatisfaction with dealer practices. $^{203}$ But if substantial elements of market power are discarded from the attempt offense, the result may be an invitation to judicial evaluation of the fairness or wisdom of such distributional decisions. Again, there is a real danger that sufficient proof of the efficiencies gained may not be found to offset the sympathetic concern that an established dealer should not lose its business without good reason.

In summary, it can easily seem unfair for a supplier to compete with, or terminate, a distributor, while proof of the efficiency justifications for so doing may be hard to come by. Courts are simply not equipped to weigh the competing concerns in the absence of a legislative policy conclusion that the interests of fairness outweigh the possible costs of efficiency. ${ }^{264}$

\section{Other Monopolizing Tactics}

The difficulties encountered in evaluating claims of predatory pricing and anticompetitive refusals to deal have been explored in moderate detail because such conduct is commonly cited as "typical"

260. See cases cited in note 261 infra. An exception is Elder-Beerman Stores Corp. v. Federated Dept. Stores, Inc., 459 F.2d 138 (6th Cir. 1972), where a discount department store complained of exclusive arrangements engineered by a rival department store with a large number of suppliers.

261. E.g., Ace Beer Distribs., Inc. v. Kohn, Inc., 318 F.2d 283, 286-87 (6th Cir.), cert. denied, 375 U.S. 922 (1963); Eastcoast Equip. Co. v. Harnischfeger Corp., 354 F. Supp. 335 (E.D. Pa. 1973); Moutoux v. Gulling Auto Elec., Inc., 1963 Trade Cas. I 70,639 (S.D. Ind. 1962).

Like results are reached when a present distributor demands the elimination of currently competing distributors. E.g., Packard Motor Car Co. v. Webster Motor Car Co., 243 F.2d 418, 420 (D.C. Cir.), cert. denied, 355 U.S. 822 (1957).

262. E.g., E.A. Weinel Constr. Co. v. Mueller Co., 289 F. Supp. 293 (E.D. Ill. 1968). 263. E.g., Carbon Steel Prods. Corp. v: Alan Wood Steel Co., 289 F. Supp. 584 (S.D.N.Y. 1968); South End Oil Co. v. Texaco, Inc., 237 F. Supp. 650 (N.D. Ill. 1965).

264. State legislation regulating relationships of the many varieties encompassed within the broad "franchise" label seems likely to place increasingly high values on the "fairness" component of the equation.

It is possible that, in time, like concern may come to be focused on relationships between "dominant" firms and their suppliers, as well as on relationships with their distributors. An independent contractor who has long supplied upholstery fabric to an automobile manufacturer, for instance, might challenge an effort to substitute internal manufacture for external purchase. Cf. I. Haas Trucking Corp. v. New York Fruit Auction Corp., 1973-2 Trade Cas. If 74,735 (S.D.N.Y. 1973). 
monopolizing behavior. The details could be elaborated considerably. Similar difficulties, often compounded by the complexity of the behavior involved, occur in evaluating the wide varieties of other conduct that has been found or claimed to violate section 2. An eclectic list ${ }^{265}$ of such conduct includes: (1) physical violence-addressed to competitors, ${ }^{286}$ their customers, ${ }^{267}$ or their products; ${ }^{208}$ (2) predatory spending-to establish "fighting brands," 200 to threaten or actually to establish new facilities ${ }^{270}$ or new products, ${ }^{271}$ to advertise, ${ }^{272}$ to create "dummy independents," 273 or simply to expand with a growing market; ;74 (3) price discrimination-in selling, , $^{275}$ or in forcing suppliers to give special advantages; ${ }^{270}$ (4) acquisition of

265. The cases cited have been selected for purposes of illustration only. None of the lists of reference is intended to be complete; generally, however, the cases selected provide references to other important discussions of the same topics. Many of the cases are intrinsically interesting or even fascinating; unfortunately, space does not allow, nor inclination prompt, a detailed summary of each.

266. See United States v. International Fur Workers Union, 100 F.2d 541, 546-47 (2d Cir. 1938), cert. denied, 306 U.S. 653 (1939); United States v. Empire Gas Corp., 5 TRAde Rec. REP. ๆ 45,072 (nos. 2271, 2272) (W.D. Mo., March 23, 1973).

267. See United States v. Dunham Concrete Prods., Inc., in Wall. St. J., June 23, 1969, at 9, col. 2 (summary of indictment). Cf. United States v. Dunham Concrete Prods., Inc., 475 F.2d 1241 (5th Cir. 1973), cert. denied, 42 U.S.L.W. 3195 (U.S., Oct. 9, 1973).

268. See Patterson v. United States, 222 F. 599, 613 (6th Cir.), cert. denied, 298 U.S. 635 (1915).

269. See Patterson v. United States, 222 F. 599, 612-13 (6th Cir.), cert. denied, 238 U.S. 635 (1915); United States v. Eastman Kodak Co., 226 F. 62, 73 (W.D.N.Y. 1915), appeal dismissed, 255 U.S. 578 (1921); United States v. Industrial Electronic Engrs., Inc., 5 TRADE REg. REP. I 45,073 (case no. 2329) (C.D. Cal., June 27, 1973). Gf. United States v. Dairymen, Inc., 5 TrADE REG. REP. If 45,073 (case no. 2312) (W.D. Ky., March 29, 1979) (flooding the market). A "fighting brand" is essentially a product used to insulate the predator's established brand from the rigors of predatory pricing.

270. See Schine Chain Theatres, Inc. v. United States, 394 U.S. 110, 119 (1948); Aloha Airlines, Inc. v. Hawaiian Airlines, Inc., 349 F. Supp. 1064 (D. Hawaii 1972), interlocutory appeal on other issues, 1973-2 Trade Cas. If 74,821 (9th Cir. 1973).

271. See Bailey's Bakery, Ltd. v. Continental Baking Co., 235 F. Supp. 705, 720, 723 (D. Hawaii 1964), affd, 401 F.2d 182 (9th Cir. 1968), cert. denied, 393 U.S. 1086 (1969). 272. See American Tobacco Co. v. United States, 328 U.S. 781, 797 (1946); Rea v. Ford Motor Co., 355 F. Supp. 842 (W.D. Pa. 1972).

273. See L.G. Balfour Co. v. FTC, 442 F.2d 1, 16, 18-19 (7th Cir. 1971).

274. See United States v. Aluminum Co. of America, 148 F.2d 416 (2d Cir. 1945); Philadelphia World Hockey Club, Inc. v. Philadelphia Hockey Club, Inc., 351 F. Supp. 462 (E.D. Pa. 1972); American Football League v. National Football League, 205 F. Supp. 60 (D. Md. 1962), affd., 323 F.2d 124 (4th Cir. 1963).

275. See Marnell v. United Parcel Serv. of America, 1971 Trade Cas. I 73,761 (N.D. Cal. 1971); McKeon Constr. v. McClatchy Newspapers, 1970 Trade Cas. If 73,212 (N.D. Cal. 1969); Union Leader Corp. v. Newspapers of New England, Inc., 180 F. Supp. 125, 141-43 (D. Mass. 1959), affd. in part, 284 F.2d 582, 587 (1st Cir. 1960), cert. denied, 365 U.S. 833 (196I).

276. See Swift \& Co. v. United States, 196 U.S. 375, 401-02 (1905); United States v. New York Great Atl. \&: Pac. Tea Co., 173 F.2d 79, 83, 87-88 (7th Cir. 1949). 
more or less direct competitors, ${ }^{277}$ or an unsuccessful attempt to acquire a competitor, ${ }^{278}$ vertical acquisitions of suppliers or customers, ${ }^{279}$ or acquisition of facilities to be closed down; ${ }^{280}$ (5) practices in exploiting, enforcing, or threatening to enforce patents ${ }^{281}$ or copyright or trademark rights, ${ }^{282}$ misuse of other kinds of litigation, ${ }^{288}$ or subversion of other governmental regulatory programs; ${ }^{284}(6)$ interference with advantageous relations by direct means, ${ }^{285}$ or by such

277. See United States v. Southern Pac. Co., 259 U.S. 214 (1922); United States v. Reading Co., 253 U.S. 26 (1920); Northern Sec. Co. v. United States, 193 U.S. 197 (1904); United States v. Molasky, 5 TrAdE REg. REP. If 45,073 (case no. 2345) (D. La., filed 1973) (summary of indictment).

278. See Union Leader Corp. v. Newspapers of New England, Inc., 180 F. Supp. 125, 142 (D. Mass. 1959), affd. in part, 284 F.2d 582 (1st Cir. 1960), cert. denied, 365 U.S. 833 (1961). It has been argued that an attempt to monopolize should have been found. See Marcus, supra note 227, at 588.

279. See United States v. Yellow Cab Co., 338 U.S. 338 (1949); United States v. Columbia Steel Co., 334 U.S. 495 (1948); United States v. Paramount Pictures, Inc., 334 U.S. 131, 173-74 (1948); United States v. Yellow Cab Co., 332 U.S. 218 (1947); United States v. Lehigh Valley R.R., 254 U.S. 255 (1920); United States v. Reading Co., 253 U.S. 26 (1920); United States v. Jerrold Electronics Corp., 187 F. Supp. 545, 568 (E.D. Pa. 1960), affd. per curiam, 365 U.S. 567 (1961).

280. See Bowl America Inc. v. Fair Lanes, Inc., 299 F. Supp. 1080 (D. Md. 1969), where the acquiring firm had the added purpose of leaving its hapless rival liable to pay rent on unoperated facilities.

281. See Agrashell, Inc. v. Hammons Prods. Co., 479 F.2d 269 (8th Cir. 1973), cert. denied, 42 U.S.L.W. 3290 (U.S., Nov. 13, 1973); Bendix Corp. v. Balax, Inc., 471 F.2d 149 (7th Gir. 1972), cert. denied, 42 U.S.L.W. 3194 (U.S., Oct. 9, 1973); Kearney \& Trecker Corp. v. Giddings, \& Lewis, Inc., 452 F.2d 579 (7th Cir. 1971), cert. denied, 405 U.S. 1066 (1972); Kobe, Inc. v. Dempsey Pump Co., 198 F.2d 416 (10th Cir.), cert. denied, 344 U.S. 837 (1952); United States v. Besser Mfg. Co., 96 F. Supp. 304, 312 (E.D. Mich. 1951), affd., 343 U.S. 444 (1952).

Cases dealing with royalty charges and discrimination are particularly interesting. See LaSalle Street Press, Inc. v. McCormick \& Henderson, Inc., 445 F.2d 84 (7th Cir. 1971); Bela Seating Co. v. Poloron Prods., Inc., 438 F.2d 733 (7th Cir.), cert. denied, 403 U.S. 922 (1971); LaPeyre v. FTC, 366 F.2d 117 (5th Cir. 1966); Peelers Co. v. Wendt, 260 F. Supp. 193 (W.D. Wash. 1966); Laitram Corp. v. King Crab, Inc., 244 F. Supp. 9 (D. Alas.), amended, 245 F. Supp. 1019 (D. Alas. 1965). See generally Hawk, supra note 86 , at $1169-70$.

282. See Alberto-Culver Co. v. Andrea Dumon, Inc., 466 F.2d 705 (7th Cir. 1972); Kellogg Co. v. National Biscuit Co., 71 F.2d 662 (2d Cir. 1934); American TCP Corp. v. Shell Oil Co., 127 F. Supp. 208 (S.D.N.Y. 1955).

283. See California Motor Transport Co. v. Trucking Unlimited, 404 U.S. 508 (1972); Forgett v. Scharf, 181 F.2d 754 (3d Cir.), cert. denied, 340 U.S. 825 (1950). Cf. United States v. Guerlain, Inc., 155 F. Supp. 77 (S.D.N.Y. 1957), vacated, 358 U.S, 915 (1958), dismissed, 172 F. Supp. 107 (S.D.N.Y. 1959).

284. See Parmelee Transp. Co. v. Keeshin, 292 F.2d 794 (7th Cir.), cert. denied, 368 U.S. 944 (1961).

285. See Hunt v. Crumboch, 325 U.S. 821 (1945); Patterson v. United States, 222 F. 599, 612-13 (6th Cir.), cert. denied, 238 U.S. 635 (1915); Forest Cove Country Club, Inc. v. National Club, Inc., BNA ANrITRUST \&. TRADE REG. REP. April 24, 1973, at A-11 (S.D. Tex., filed April 6, 1973). Cf. Eastern Pre-Cast Corp. v. Giant Portland Cement Co., 311 F. Supp. 896 (E.D. Pa. 1970). 
other means as misrepresentations,, ${ }^{286}$ disparagement, 287 "surveillance,"288 or advance announcement of new products well before their actual market availability; 280 and (7) preclusion of competitive opportunities through exclusive dealing requirements imposed on customers or suppliers, ${ }^{290}$ tying, ${ }^{201}$ designing separate products for integral use, ${ }^{292}$ influencing purchasers to adopt restrictive purchase specifications, ${ }^{293}$ threatening to enter into competition with customers who purchase from rivals, ${ }^{294}$ or obtaining covenants against competition or revelation of competitive information. ${ }^{205}$

Individualized exploration of each category of conduct would require inordinate time. For present purposes, the illustrations provide a richer framework than predatory pricing and refusals to deal

286. See Aloha Airlines, Inc. v. Hawaiian Airlines, Inc., 349 F. Supp. 1064 (D. Hawaii 1972), interlocutory appeal on other issues, 1973-2 Trade Cas. If 74,821 (9th Cir. 1973); Union Leader Corp. v. Newspapers of New England, Inc., 180 F. Supp. 125, 141 (D. Mass. 1959), affd. in part, 284 F.2d 582 (1st Cir. 1960), cert. denied, 365 U.S. 833 (1961).

287. See L.G. Balfour Co. v. FTC, 442 F.2d 1, 17-18 (7th Cir. 1971); Bernard Foods Indus. v. Dietene Co., 415 F.2d 1279 (7th Cir. 1969), cert. denied, 397 U.S. 912 (1970); Keco Indus. v. Borg-Warner Corp., 334 F. Supp. 1240 (M.D. Pa. 1971). Cf. Household Goods Carriers' Bureau v. Terrell, 417 F.2d 47 (5th Cir. 1969), reh. en banc, 452 F.2d 152 (5th Cir. 1971).

288. See Patterson v. United States, 222 F. 599, 612 (6th Gir.), cert. denied, 238 U.S. 625 (1915); United States v. General Elec. Co., 82 F. Supp. 753, 901 (D.N.J. 1949), modified, 115 F. Supp. 835 (D.N.J. 1953).

289. See Telex Corp. v. International Business Machs. Corp., 1972 Trade Cas. If 74,183 (D. Minn.), revd. per curiam, 464 F.2d 1025 (8th Cir. 1972), as an illustration of this now very popular claim.

290. See L.G. Balfour Co. v. FTC, 442 F.2d 1, 14-16, 19-20 (7th Cir. 1971); Cherokee Labs., Inc. v. Rotary Drilling Servs., Inc., 383 F.2d 97, 106-07 (5th Cir. 1967), cert. denied, 390 U.S. 904 (1968); Twin City Sportservice, Inc. v. Charles O. Finley \& Co., 365 F. Supp. 235 (N.D. Cal. 1972); United States v. Standard Oil Co., 362 F. Supp. 1331 (N.D. Cal. 1972), affd. per curiam, 412 U.S. 924 (1973); Marnell v. United Parcel Serv. of America, Inc., 1971 Trade Cas. If 73,761 (N.D. Cal. 1971).

291. See Times-Picayune Publishing Co. v. United States, 345 U.S. 594 (1953); Lessig v. Tidewater Oil Co., 327 F.2d 459 (9th Cir.), cert. denied, 377 U.S. 993 (1964); Kansas City Star Co. v. United States, 240 F.2d 643 (8th Cir.), cert. denied, 354 U.S. 923 (1957).

292. Cf. Telex Corp. v. International Business Machs. Corp., 1973-2 Trade Cas. I 74,774 (N.D. Okla. 1973).

293. See Federal Sign \& Signal Corp. v. Bangor Punta Operations, Inc., 357 F. Supp. 1222 (S.D.N.Y. 1973).

294. See United States v. Jerrold Electronics Corp., 187 F. Supp. 545, 568-69 (E.D. Pa. 1960), affd. per curiam, 365 U.S. 567 (1961).

295. See Schine Theatres, Inc. v. United States, 334 U.S. 110, 119 (1948); Board of Trade v. Christie Grain \& Stock Co., 198 U.S. 236 (1905); Alders v. AFA Corp., 353 F. Supp. 654 (S.D. Fla. 1973); Philadelphia World Hockey Club v. Philadelphia Hockcy Club, Inc., 351 F. Supp. 462 (E.D. Pa. 1972); Miller v. Kimberly-Clark Corp., 339 F. Supp. 1296 (E.D. Wis. 1971); Michigan Bar Review Center, Inc. v. Nexus Corp., 1971 Trade Cas. \73,700 (E.D. Mich. 1971); Syntex Labs., Inc. v. Norwich Pharmacal Co., 315 F. Supp. 45 (S.D.N.Y. 1970). 
for suggesting the more important general questions that must be asked in assessing competitive behavior.

Most important, attention must focus on the similarity of the challenged behavior to the general descriptive qualities of ordinary business behavior. If, as usually happens, the challenged conduct is similar, attention must be diverted to the magnitude of the behavior in relationship to the patterns established by other firms. All firms may engage in promotional campaigns, for instance, but a campaign of free goods to all comers for a year would be highly suspicious.

Internally consistent patterns of behavior over time and between geographic or product markets may be as important as consistency with patterns of behavior established by other firms. A firm that has followed a challenged practice for many years may be viewed differently than a firm that has suddenly altered its tactics, particularly if the new practice seems to be addressed to a particular adversary rather than to the market as a whole. So, too, a firm engaged in many markets may quite legitimately introduce new patterns of behavior from one market to another.

All of the factors previously detailed must also be examined from the perspective of the firm charged with anticompetitive behavior. Evaluation of its market power, and even its over-all wealth, helps to assess the probable impact, duration, and motivation of its conduct. Evaluation of its intent helps to predict impact, to assess assertions of economic justification, and to reexamine the estimate of market power. Since direct evidence of subjective motives and expectations is at best treacherous, the evaluation of intent itself must often depend heavily on the objective circumstances of conduct and market setting; in many cases, circumstantial evidence of intent will prove helpful only when there are strong indications of some particular motivating factor, whether of justification or aggravation. When several items of conduct are challenged, moreover, it is necessary to undertake a global view of their relationship to each other, as well as to the balance of the firm's conduct and its circumstances.

Finally, there remains the vitally important inquiry whether the challenged conduct has any arguable tendency to promote economic efficiency. The excruciating difficulty of this inquiry may be underscored by returning to the question of reciprocity. Reciprocity practices have been attacked as attempts to monopolize in circumstances that clearly have not involved any approach to monopoly power. ${ }^{296}$

296. See text accompanying notes 10-11 supra. 
Presumably the justification lies in a belief that such practices are without efficiency-redeeming virtue. The unfortunate difficulty is that efficiencies are possible, basically by reducing dependency on uncertain and unpredictable market operations. Without undertaking a review of the expansive literature, ${ }^{207}$ it should suffice to state that the possibilities of efficiency have not been so clearly debunked as to justify casual outlawry. Easy resort to attempt doctrine in this area would provide one further demonstration of the dangers of being misled by the obvious tendency of reciprocity practices to foreclose access to customers into a conclusion that illegality can be found without additional painstaking inquiry.

\section{B. Other Dangers of Judicial Regulation}

\section{Deterring Desirable Conduct}

A significant expansion of monopolization and attempt concepts may deter desirable competitive behavior for reasons other than the immediate danger of mistaken judicial evaluation. As courts become willing to evaluate competitive behavior across a broad array of market settings, business firms must become increasingly wary of disruptive competitive behavior. The more frequent the occasions for requiring judicially satisfactory demonstration of the justification for new ways of doing business and the greater the uncertainty as to the permissible limits of behavior, the less attractive business innovation will be.

The danger of deterring desirable behavior is accentuated by the nature of antitrust penalties. Even if business managers believe that the self-restraint of government officials will preclude criminal prosecutions of any but the most heinous behavior, it is intrinsically unsatisfactory to expand the categories of crime by judicial decision. ${ }^{208}$ This difficulty has led to arguments that only civil sanctions should apply to an expanded monopolization offense. Criminal penalties would be avoided by imputing to the statute a requirement of specifically wrongful "intent." 299 Although there is no real judicial support for this approach, there is no clearly contrary authority either. If accepted, the same process could be used for attempts; the "specific intent" requirement could be resurrected as a means of at least

297. An excellent discussion is found in chapter 9 of a forthcoming work of Professor Peter Steiner, tentatively titled MERGERs: MotrVEs, EFFEcrs, Policies (University of Michigan Press).

298. A brief personal statement of these dangers is set out in the Appendix.

299. E.g., Turner, supra note 53, at 1221-23 (treble damage actions are also ruled out with less explanation of reasoned evasion of the statutory remedy). 
theoretically curtailing the dangers implicit in judicial expansion of criminal prohibitions.

Fear of private litigation might suffice to chill desirable competitive activity more effectively than the threat of government litigation. Private litigants are already adding attempt charges to antitrust complaints as a matter of routine. ${ }^{300}$ Treble damage sanctions would remain, even if it were possible somehow to separate out a category of noncriminal monopolization and attempts to monopolize. This easy resort to litigation might be curtailed if, by some feat of judicial force, private litigants were confined to single damages or even to injunctive relief alone. Nonetheless, it would seem hard to rely on the self-restraint of litigants to ensure that only well-founded suits are brought.

\section{Competitors' Misuse of Antitrust}

Beyond these obvious concerns with the deterrent effects of uncertain substantive doctrine and harsh penalties lie a different, but equally troubling, variety of doubts. Private litigants have already asserted attempt claims in efforts transparently designed to shield against desirable, effective competition. Although the defendants have so far prevailed, the very ability to impose on competitors the heavy burden of antitrust litigation over claims that cannot be dismissed at the outset is dangerously anticompetitive in itself. A few illustrations should demonstrate the perils that may result.

The most extreme example is a case in which a firm that enjoyed more than 70 per cent of the California baby food market asserted attempt to monopolize claims, among others, against a rival who, at its peak, had gathered 6.6 per cent of the market. The defendant's wicked stratagem, in an effort to halt a declining market share, had · been the sale of baby food in glass containers at the same price as the plaintiff was charging for baby food in metal containers. ${ }^{301}$ In another case, a bank that had bid unsuccessfully for a checkless payroll arrangement with local school boards sued the successful bidder on a claim that the arrangement itself constituted an attempt to monopolize. ${ }^{302}$ In a third case, small dairy processors sued to halt construc-

300. See Hibner, supra note 37 , at 167.

301. Gerber Prods. Co. v. Beech-Nut Life Savers, Inc., 160 F. Supp. 916 (S.D.N.Y. 1958) (suit was later voluntarily dismissed). Cf. H.J. Heinz Co. v. Beech-Nut Life Savers, Inc., 181 F. Supp. 452 (S.D.N.Y. 1960). Cliff Food Stores, Inc. v. Kroger, Inc., 417 F.2d 203 (5th Cir. 1969), is similar in principle although not in drama; so too is Allen Ready Mix Concrete Co. v. John A. Denie's Sons Co., 1972 Trade Cas. If 73,955 (W.D. Tenn. 1972). 302. Bank of Utah v. Commercial Sec. Bank, 369 F.2d 19 (10th Cir. 1966), cert. denied, 
tion by a big grocery chain of a large new processing facility in the apparent fear that they could not compete successfully if it were completed; the court affirmed dismissal of their complaint with the tart observation that "Plaintiffs' market shares are not protected by the anti-trust laws and they have no legal basis for precluding competition of Kroger in their field." 303

Pathological cases such as these are important in themselves. In addition, they underscore a more fundamental point. In such clear situations, it is relatively easy to be confident that the plaintiffs were trying to use the antitrust laws as a shield against efficient, socially desirable competition. The danger is that in less clear cases a decision will be made to interfere with private behavior that is equally desirable. The broader the invitation that is extended to competitors to use the judicial process, the greater the opportunity, and inevitably the occurrence, of severely anticompetitive judicial decisions.

\section{Jury Trial}

Finally, any honest discussion of judicial competence to evaluate the competitive system must consider the fact that the resolution of such disupted matters as "intent"-and therewith the entire evaluation of the desirability of competitive conduct-lies with the jury. ${ }^{304}$ Others have noted the risks involved in this procedure; ${ }^{305}$ it is suffcient now to note that jury trial must aggravate the burdens of uncertainty imposed on business planning and result in arbitrary differences in deciding cases.

386 U.S. 1018 (1967). See also Clark v. United Bank of Denver Natl. Assn., 480 F.2d 235 (10th Cir.), cert. denied, 42 U.S.L.W. 3270 (U.S., Nov. 6, 1973). It is not entirely uncommon for plaintiffs to attack practices in which they themselves have indulged, perhaps with less success than the defendants. E.g., Federal Sign \& Signal Corp. v. Bangor Punta Operations, Inc., 357 F. Supp. 1222 (S.D.N.Y. 1973).

303. Hiland Dairy, Inc. v. Kroger Co., 402 F.2d 968, 977 (8th Cir. 1968), cert. denied, 395 U.S. 961 (1969).

Senator Stewart, whose other views on the pending antitrust legislation were hardly elegant, observed that, under Senator Sherman's bill, "It would be the accumulated capital that would prosecute the new concerns that are starting. This bill would be an engine of oppression to break down all competition ... ." 51 Conc. REc. 2606 (1890). Perhaps, in time, he may yet be proved right.

304. Illustration of the issues left to the jury is provided by the expansive opinion in Rea v. Ford Motor Co., 355 F. Supp. 842 (W.D. Pa. 1972).

305. E.g., Sections 1 and 2 of the Sherman Act Generally: Developments at Large and Portents of Things to Come, A Panel Discussion, 37 ANTTrRust L.J. 657, 680.81 (1968). Still others, of course, accept jury determination of such matters with equanimity. E.g., Blecher, supra note 2, at 217-18. 


\section{Resolution and Gonclusion}

Substantial advantages may be achieved by expanding section 2 to reach the behavior of a single firm whose market power does not approach the present legal concept of monopoly power. In terms of the examples in the Introduction, courts seem fully capable of controlling at least some forms of market-entrenching behavior by oligopoly firms, of imposing sanctions on conduct that is revealed to be predatory by self-confession, and of prohibiting efforts to enforce fraudulently procured patents. As time goes on, it may be possible to add other categories of conduct to the catalogue of single-firm behavior that is so threatening to the competitive values attributed to the Sherman Act, and that can be so clearly evaluated by the courts, as to justify similar treatment.

Expanded control of single-firm behavior, however, would be better undertaken by redefining the role of market power in the monopolization offense than by expanding the attempt offense. Misbehavior of an oligopolist would be measured against its share of collective monopoly power, even though it lacked distinctive monopoly power of its own. Clearly outrageous conduct, such as enforcement of a fraudulently procured patent, could be reached without measuring market power at all. This path of expansion would have many advantages: As a purely pragmatic matter, it might instill a commendable desire to act only after reaching a thorough understanding of the activity involved in its full market setting; as a matter of legal doctrine, it would draw strong support from the classic definitions of monopolization as single-firm conduct that threatens to produce the same evils as concerted action unlawful under section 1; and as a matter of intellectual honesty, it would have the great advantage of not creating the sorry spectacle of a criminal attempt offense that did not embody any elements of approach to the completed offense.

If monopolization doctrine were thus expanded, it would be even more difficult to understand the awkward residual role played by present attempt doctrine. The requirements that there be a specific intent to monopolize and a dangerous probability of success, without monopolizing, could not be meaningfully distinguished from monopolization itself. The best course would be to repeal the attempt provision with an explicit statement that courts should condemn as monopolization all varieties of single-firm conduct found to warrant control after appraising all available proof of subjective intent, objective conduct, and market power. Although repeal has been proposed 
as part of general revision of the criminal code, ${ }^{306}$ the simultaneous creation of a general attempt offense would probably renew the old problems. Repeal in any other manner seems highly unlikely.

Absent repeal, courts will be left with the obligation to define the attempt offense as'well as they can. They should accord no more than perfunctory content to the statutory phrase by characterizing the least offensive varieties of conduct found unlawful as attempts rather than monopolization. So long as the true character of this process is understood, there seems little harm in continuing to use "dangerous probability" terminology as a token explanation. The "specific intent" requirement, on the other hand, should be redefined. Courts should recognize explicitly that the central task is an evaluation of the conduct involved in its full market setting. Direct evidence of subjective motivations is always relevant in evaluating conduct, but inferences of motivation are ordinarily too dangerous to be accorded substantial weight.

Expansion of the attempt offense beyond this arbitrary and essentially subsidiary role is not warranted. Current arguments for expansion amount to an effort to create a federal common law of unfair competition. In the past, courts have repeatedly refused to use the Sherman Act in this way, ${ }^{307}$ instinctively recognizing that efforts to control the "fairness" of competition must encounter immense difficulties. In addition to the difficulties of evaluating any but the most flagrant forms of conduct sketched above, the expansion of regula-

306. The proposed Criminal Justice Codification, Revision and Reform Act of 1973 would delete the attempt to monopolize offense from section 2 and replace it with a general criminal attempt provision. S. 1, 93d Cong., lst Sess. §§ 1-2A4, 316(a)(2) (1973).

By way of contrast, section 3 of the recently approved Uniform State Antitrust Act prohibits: "The establishment, maintenance, or use of a monopoly, or an attempt to establish a monopoly, of trade or commerce in a relevant market by any person, for the purpose of excluding competition or controlling, fixing, or maintaining prices." 4 TRADE REG. REP. I 30,101. So long as the Sherman Act is cast in its present form, it may make good sense to cast uniform state legislation in terms that partly draw from the familiar federal model.

307. E.g., Hunt v. Crumboch, 325 U.S. 821 (1945); Apex Hosiery Co. v. Leader, 310 U.S. 469, 483, 497-500, 512-13 (1940); Harrison v. Prather, 435 F.2d 1168, 1176-77 (5th Cir.), cert. denied, 404 U.S. 829 (1970); Ace Beer Distribs., Inc. v. Kohn, Inc., 318 F.2d 283 (6th Cir.), cert. denied, 375 U.S. 922 (1963) (typical of cases expressly foregoing determination of the existence of unfair competition claim in finding a lack of antitrust violations); B \& B Oil \& Chem. Co. v. Franklin Oil Corp., 293 F. Supp. 1313 (E.D. Mich. 1968).

Commentators commonly approve this approach. E.g., $2 \mathrm{~J}$. voN KALINowski, supra note 37, \$ 9.01 [2], at 9-10 to -11 n.32; Hibner, supra note 37, at 171 . A statement of the need to avoid confusing the law by making a clear, intentional choice whether to pursue such a course is found in Director \& Levi, Law and the Future: Trade Regulation, 51 NW. U. L. REv. 281 (1956). 
tion might well force courts to undertake detailed administration of continuing business behavior. ${ }^{308}$ A great.need to contain a rampaging economy of cutthroat competition would have to be shown to justify such sweeping involvement with the intractable problems of competition. The remaining introductory examples of reciprocity and competition by a supplier with its own distributors are not persuasive. No more persuasive examples have yet been offered.

The direct costs of mistaken evaluation of competitive behavior are supplemented by the indirect costs of deterring desirable behavior. The greater the uncertainty created by expansive judicial evaluation, the greater the dangers of deterrence. How far such dangers are realized depends very much on the extent to which business managers believe that their decisions will be subject to antitrust scrutiny. It seems likely that a very broad expansion would be required to influence many business decisions in more than marginal or cosmetic ways. To the extent that business conduct is left unaffected, however, the result may be a not uncommon antitrust phenomenon: a wide variety of conduct that is theoretically unlawful flourishes unchecked, with antitrust sanctions imposed arbitrarily on a very small segment of the forbidden behavior. In such circumstances, it is difficult to believe that any good is accomplished by sporadic findings of violation.

The difficulty of evaluating competitive behavior is not substantially affected by the source of authority to undertake the regulation. If unfair competition doctrines are nonetheless to be expanded, section 2 of the Sherman Act is an inappropriate vehicle. Criminal penalties are simply inappropriate to the lesser sins of unfair competition, but there is little assurance that such penalties could be avoided entirely. Treble damage penalties are likewise inappropriate, but there is virtually no hope that they could be eliminated for the least offensive wrongs. The obvious alternative is further development of state law. If state law is thought too faltering, ${ }^{309}$ however, there are alterna-

308. Detailed regulation of competitive practices ordinarily left to unfettered business judgment is seen in Credit Bureau Reports, Inc, v. Retail Credit Co., 358 F. Supp. 780 (S.D. Tex. 1971), affd., 476 F.2d 989 (5th Cir. 1973). Comparable regulation may be achieved by consent decree. See United States v. Times Printing Co., 1970 Trade Cas. If 73,090 (E.D. Tenn. 1970). At times, it may prove possible to pass the probléms back to an administrative agency. See Otter Tail Power Co. v. United States, 410 U.S. 366 (1973).

309. It seems likely that in many areas the lag in development of thorough-going principles of unfair competition is attributable to the reluctance of common law courts. In areas involving the imitation of such commercial values created by a competitor as formulas, designs, collections of information, and the like, overhanging shadows of federal preemption may have chilled further development. Even as to 
tive courses available for federal action apart from expansive interpretation of section 2.

One possibility is to develop the provisions of the Lanham Trademark $\mathrm{Act}^{310}$ into a generalized body of unfair competition doctrine. The case against this form of interpretation is strong; ${ }^{311}$ it is not as strong as the case against achieving comparable results under the Sherman Act, because of the absence of criminal or treble damages liability.

A second possibility is to develop a private remedy for violation of section 5 of the Federal Trade Commission Act. Courts have, so far, uniformly rejected this proposal; ${ }^{312}$ the statute seems so clearly designed for administrative application that any such step surely can only be effected through new legislation. ${ }^{313}$

The third possibility is to authorize, by statute, creation of a federal common law of unfair competition. It seems virtually impossible to justify creation of such a body of common law without an enabling jurisdictional statute; there is little force in the argument that competitive conditions are so far touched by the federal antitrust, unfair competition, patent, copyright, and trademark statutes, as well as treaties with other countries, as to require exclusive or concurrent federal occupation of the field..$^{314}$

Other possibilities might be conjured up. Whatever theory is of-

imitation, however, there is perhaps more room for state law than had been thought. See Goldstein v. California, 412 U.S. 546 (1973).

310. 15 U.S.C. $\$ \S 1051-127$ (1970). Particular reliance is placed on section 43(a), 15 U.S.C. $\S 1125$ (a) (1970), which clearly creates a private remedy for practices far narrower than the entire field of unfair competition, and on the intricate relationship between subsections (b), (g), (h), and (i) of section 44, 15 U.S.C. \$§ 1126(b), (g), (h), (i) (1970).

311. See Derenberg, Federal Unfair Competition Law at the End of the First Decade of the Lanham Act: Prologue or Epilogue?, 32 N.Y.U. L. REv. 1029 (1957).

312. See, e.g., Holloway v. Bristol-Myers Corp., 485 F.2d 986 (D.C. Cir. 1973); Carlson v. Coca-Cola Co., 483 F.2d 279 (9th Cir. 1973). Arguments that such a remedy should be created are set out in Bunn, The National Law of Unfair Competition, 62 HARv. L. REv. 987 (1949), and in the dissenting opinion in the Garlson case, 483 F.2d at 281-83 (Solomon, J., dissenting).

313. The subtle intricacies of administrative reasoning lead, at times, to results beyond the probable sophisticated application of many legal minds. A paltry recent illustration of an honorable tradition is provided by Sunshine Art Studios, Inc. v. FTC, 481 F.2d 1171 (1st Cir. 1973). One of the acts of unfair competition there found was advertising that "free" imprinting was available with greeting cards. Cards sold without imprinting were indeed sold for the same price as cards with imprinting. But there had never been a separate and lower charge for nonimprinted cards. Accordingly, it was concluded that the purchasers of imprinted cards were not getting something free; instead, they were paying the regular price, while customers for nonimprinted cards were simply receiving merchandise of lesser value.

314. Cf. Cooper, State Law of Patent Exploitation, 56 MiNn. L. Rev. 313 (1972). 
fered, the formidable dangers of undue intrusion should preclude courts from imposing their own notions of orderliness on the disarray of the marketplace. The mainstream of current attempt doctrine, although difficult to comprehend intellectually, represents a healthy perception of these dangers. Little reform is needed; the most important step would be to recognize the artificiality of most "specific intent" statements. This step would bring attempts closer to monopolization, with primary attention focused on evaluation of conduct in its market setting. The alternative path of expanding attempts in an independent direction away from monopolization might lead to undue extension of judicial control over misunderstood competitive practices. Courts should not walk these paths without greater legislative guidance.

\section{APPENDIX: ATTEMPTS AS JUDICIAL CRIMEMAKING}

Efforts to expand the prohibition against attempts to monopolize have invariably focused upon the treble damage or injunctive remedy. Indeed, it hardly seems proper to intrude into polite antitrust discourse the reminder that section 2 defines criminal offenses. Nonetheless, the criminal sanctions remain; they deserve serious consideration as long as judges show no inclination to create separate civil and criminal violations of section 2.

As noted briefly in the body of this article, ${ }^{315}$ there is no reason to believe that the draftsmen of section 2 intended that the attempt offense be used in any way other than the ordinary criminal law method of analogy and close approach to the cognate completed offense. Old statutes, however, are not uncommonly put to entirely unexpected uses; it is not enough to respond to a plea of contemporary need with an assertion that the need was not contemplated by the drafters. If development of the attempt concept into an offense completely independent of monopolization is thought desirable, the development is apt to occur. The purpose of this Appendix is to suggest that the potential availability of criminal sanctions should be weighed in determining whether "attempts to monopolize" should be expanded. To some extent, development of monopolization doctrine should also proceed slowly. No one of the arguments is compelling in isolation; together, they may add considerable force to a plea for judicial circumspection.

\section{Crimemaking by Analogy ${ }^{316}$}

The general purpose of attempt doctrine in criminal law is to fill the gaps that inevitably appear in defining a completed crime. The

315. See Part IV(C) supra.

316. Greatest reliance for the ideas sketched in this section has been placed on 
judicial task is one of extending the crime, through attempt doctrine, by a process of analogy to the completed offense. The process must work by reference to the legislative interests effectuated by the completed offens $\mathrm{e}^{317}$ and their bearing on the conduct before the court. ${ }^{318}$ The requirements of specific intent and of dangerous probability of attaining monopoly power in a relevant market are imposed on attempted monopolization by the dominant line of current authority in clear response to the belief that attempts should be defined by this process of analogy to the completed offense. Even this process of analogy to completed monopolization involves substantial difficulties. Without examining the many varieties of potentially undesirable behavior catalogued earlier, a homely illustration may illuminate the difficulties.

Some extreme forms of conduct are readily found criminal. Deliberately shooting a person is murder; shooting and missing may easily be found to be attempted murder in many circumstances. Deliberately destroying a sole competitor's plant by dynamite is, among other things, monopolization; seeking to destroy the plant by dynamite that is defused at the last minute might be found to be an attempt to monopolize. At the other extreme, driving an automobile, although inherently dangerous, is not attempted murder nor even attempted vehicular homicide; competing, although inherently dangerous to rivals, is not attempted monopolization. In between such extremes of conduct the difficulties of analogy may become enormous.

Specific statutory offenses have been created to impose sanctions on unduly dangerous driving. The creation of such offenses has worked tolerably well because there is a consensus as to the acceptable limits of behavior, which can be used to warn drivers in advance and to guide courts in applying the law. Any effort to make attempts to monopolize into an offense of reckless competition, on the other hand, must collide immediately with the difficulty of providing standards of legitimate conduct. References to intent are not helpful, since the intent to injure a rival by depriving him of business is the wholly innocent and laudable intent of good competition; reliance on evaluation of competitive conduct invites the vast confusions sketched earlier.

Arnold, Criminal Attempts-The Rise and Fall of an Abstraction, 40 YALE L.J. 53 (1930), and on Enker, Impossibility in Criminal Attempts-Legality and the Legal Process, 53 MinN. L. REv. 665 (1969).

317. E.g., Arnold, supra note 316, at 76; Perkins, Criminal Attempt and Related Problems, 2 UCLA L. REv. 319, 324-25 (1955).

318. E.g., Ryu, Contemporary Problems of Criminal Attempts, 32 N.X.U. L. REv. 1170,1175 (1957). An illustration of just how badly the interest identification approach can go astray is provided by some of the examples of application offered in Strahorn, The Effect of Impossibility on Criminal Attempts, 78 U. PA. L. REv. 962, 970, 975.77, 984.85 (1930). 
In terms of creating criminal liability, the problem is simply that the courts are entering an area in which it is highly difficult to define in advance the limits of legality or even to distinguish the lines in retrospect.

Courts seem to have reacted instinctively to these dangers in their apparent unwillingness to expand attempts to reach a near monopolist who engages in potentially beneficial conduct that would be forbidden to a monopolist. ${ }^{318}$ The dangers are equally present, however, in reacting to seemingly less justifiable conduct.

These problems result primarily from the fact that section 2 creates common law crimes for economic regulation. ${ }^{320}$ Whether conduct that has been found unlawful is called monopolization or attempted monopolization is immaterial. In either case, conviction is the result of judical definition. The very lack of criminal enforcement is itself implicit recognition of the unsuitability of imposing criminal sanctions through such a common law process.

Developing criminal definitions in this fashion runs head-long into the values embedded in the so-called principle of legality. ${ }^{321}$ Most simply, this principle means that retrospective government intervention into private affairs, particularly where penal sanctions are imposed, cannot serve the purposes of law unless it is according to rules that the actors have an opportunity to know in advance. The Supreme Court, in overturning a vagrancy law, has inveighed against the grave dangers of crime by analogy. ${ }^{322}$ Persons engaged in business are no more anxious (or deserving) to be clapped in jail or to be overcome by a plague of treble damage suits for crimes of analogy to an abstract judicial model of fair competitive behavior. The dangers are not reduced by recasting the conclusion into one of monopolization rather than one of attempt by analogy to monopolization.

The problems of judicial crimemaking, moreover, would only be exacerbated by entirely discarding the process of analogy, as suggested by the contemporary argument for expansion of the attempt offense. Two cases noted earlier ${ }^{323}$ illustrate the problem clearly. In each, the court ruled that an unfair effort by an automobile manufacturer to become the sole retail seller of its own products could be found to be an attempt to monopolize, even though success would not be monopolization. For the reasons sketched earlier, ${ }^{324}$ it does not seem appropriate for courts to undertake to control such relationships under any

319. See Part $\mathrm{I}(\mathrm{C})(3)(\mathrm{b})$ supra.

320. See Part IV(C) supra.

321. E.g., J. HAal, Generax Pringiples of Criminal Law 575-76 (2d ed. 1960).

322. See Papachristou v. City of Jacksonville, 405 U.S. 156, 168-69 (1972).

323. See text accompanying notes $8,171-75$ supra.

324. See Part $\mathrm{V}(\mathrm{A})(2)$ supra. 
conclusional label. A requirement that there be a close analogy to something that the court is prepared to characterize as completed monopolization is apt to restrain judicial willingness to condemn. Once that restraint is put aside, the dangers of mistaken regulation are proliferated by the very fact that courts would be defining an offense of unfair competition for which criminal sanctions are at least theoretically available.

\section{Purposes of Punishment}

Quite apart from problems of fairness, little purpose is served by attaching to sins of unfair competition the criminal penalties available for attempts to monopolize. A brief review of the commonly recognized purposes of criminal attempt doctrine should serve to test the point. ${ }^{325}$

Among the purposes of punishing attempts may be those of relieving a community sense of fear and outrage over the conduct involved and of expressing a community sense of superiority and righteousness. The dangers of such retributive motives are always great; with respect to the sins of unfair competition that could be embraced by an open-armed attempt offense, the dangers are very great that punishment would depend simply on the sensibilities of the particular tribunal. As the offense expands toward conduct that can be found with only imperceptible variations in a wide variety of ordinary and legitimate business ploys, the dangers of decision drawn from the bias of the individual judge or jurors are multipled.

In addition, attempts may be punished because of a feeling that the actor is a person sufficiently dangerous to warrant some form of incapacitation from committing further crimes and some measure of rehabilitative effort. The actual record of antitrust law in these respects is at least as dismal as that of criminal law generally. More fundamentally, if there is grave doubt about the capacity of judicial tribunals to identify conduct that warrants even prospective prohibition, there can be no question of their incapacity to identify dangerous competitive actors who require such therapy as our penal systems may have to offer.

Another goal of attempt doctrine is to treat actors who are apparently as "guilty" as those who have completed an offense, but whose conduct, by some fortuity, has fallen short of the completed crime, in the same way as those who have completed an offense are treated. ${ }^{320}$ At most, this purpose would justify reaching only those who have

325. Cf. Elkind, Impossibility in Criminal Attempts: A Theorist's Headache, 54 VA. L. REV. 20, 29-30 (1968).

326. E.g., Wechsler, Jones \& Korn, The Treatment of Inchoate Crimes in the Model Penal Code of the American Law Institute: Attempt, Solicitation, and Conspiracy, 61 Colum. L. Rev. 571, 572-73 (1961). 
very narrowly missed the combination of power and conduct required for monopolization. More realistically, it must be wondered whether this purpose has any meaningful application to situations as complicated as those necessarily found in the precincts of section 2.

Attempt doctrine also responds to a perceived need to permit official intervention to thwart undesirable results before they are completed without losing the opportunity to invoke the criminal process. ${ }^{327}$ This purpose may be served if it is possible to identify situations of competitive behavior analogous to pointing a loaded gun at another person. Identification continues to be the question.

Finally, many writers are reluctant to suppose that punishment for attempt can very often serve a deterrent function above that provided by punishing the completed crime. ${ }^{328}$ Independent significance is so seldom given to attempt to monopolize doctrine that deterrence may seem particularly unlikely. Nonetheless, the purpose of deterrence may be served by punishing attempts to monopolize, at least if business managers are able to identify in advance the kinds of conduct that constitute an attempt to monopolize. Most obviously, expanding the reach of attempts to include reduced combinations of power and conduct is apt to warn people to remain further away from the core violation; since the conduct involved ordinarily continues over time, approaching gradually toward the prohibited zone, ample opportunity exists for reflection on the dangers of persistence. In addition, if deliberate predation is used as a model, it is possible to build a decisional theory that would be strongly influenced by punishment for mere attempt. In determining whether to monopolize, the would-be monopolist must consider the probability of acquiring monopoly, the costs of acquisition, and the profits that would be obtained if it were acquired. The calculation must include the possibility that judicial intervention will reduce the profits and increase the costs. If a mere attempt is subject to intervention and punishment, the calculation must include the decreased probability of ever attaining monopoly and the increased risk that costs will be imposed by judicial action without ever enjoying offsetting profits.

\section{Griminal Nonenforcement}

To be sure, these observations are subject to the retort that no one is proposing the use of criminal penalties to enforce the expanded portion of the attempt offense. This disclaimer of criminal enforce-

327. E.g., Enker, supra note 316, at 696.

328. E.g., W. LAFave \& A. Scotr, JR., Handbook on Crominal LaW 427-28 (1972); Wechsler, Jones \& Korn, supra note 326 , at 572. In contrast, it is often urged that allowing a defense of voluntary withdrawal is desirable in order to encourage voluntary cessation that might not occur if the actor had already incurred the full penalty. E.g., W. LAFAve \& A. ScotT, JR., supra, at 450. 
ment itself supports the proposition that this criminal statute should not be used to expand judicial control over single-firm competitive behavior. The only justifications for reliance on section 2 must be that there is no other means for creating a federal common law tort of unfair competition and that there is no realistic hope that Congress will create such a tort. These arguments of themselves demonstrate that courts should not seize upon section 2 as a contrived justification for action. 